\title{
ŚWIATOPOGLĄD KONSTANTEGO JELEŃSKIEGO. PRÓBA REKONSTRUKCJI
}

\author{
Paweł BEM (Warszawa)
}

\section{„Ferdydurke zmieniło moje życie” — deszyfrator rzeczywistości i jego alter ego}

To był rok 1937, jeszcze na dwa lata przed maturą, wybuchem wojny i opuszczeniem kraju na zawsze. Ciotka Jeleńskiego, Magda Skarżyńska, wręczyła mu książkę, która, jak się zdaje, okazała się najważniejszą lekturą jego życia — zdeterminowała spojrzenie na rzeczywistość. Moment ten wspomina następująco:

Moja ulubiona ciotka Magda była przyjaciółką Reny Gombrowiczówny, siostry Witolda (obie były wiceprezeskami Związku Młodych Ziemianek). Uchodziłem w rodzinie za zapamiętałego czytelnika, toteż moja ciotka wręczyła mi tę książkę o dziwacznym tytule: „Napisał to brat Reny. Nic z tego nie rozumiem, a Rena boi się, że brat zwariował. Co o tym myślisz?". Miałem wtedy piętnaście lat i jak to się często zdarza, od dziecka wydawało mi się, że istnieje jakiś klucz, którego jestem pozbawiony, a który pozwoliłby mi zrozumieć, co się wokół mnie naprawdę dzieje. Ferdydurke była dla mnie tym kluczem: ja sam, moja rodzina, szkoła, cały kraj, wszystko to zlało się nagle w czytelny dla mnie obraz, jak złożone wreszcie części skomplikowanej łamigłówki. Nie wymagało to z mojej strony żadnej przenikliwości. W tej książce trzydziestoletni autor przemienia się w chłopca w moim wieku i opisuje mój dzień powszedni tu i teraz (tam i wówczas). Środowisko Gombrowicza było identyczne z moim. Ten sam rodzinny dwór neoklasycystyczny z XVIII wieku, ta sama służba i z rzadka widywani chłopi (dalekie, szare sylwetki, zlewające się w pejzaż), ci sami postępowi znajomi warszawscy moich lekkomyślnych i ,nowoczesnych” rodziców, ta sama szkoła, gdzie większość kolegów uległa wzrastającej właśnie fali faszyzującego nacjonalizmu, na który reagowałem wstrętem ${ }^{1}$.

${ }^{1}$ K. A. Jeleński, „Ferdydurke” po pięćdziesięciu latach, [w:] tegoż, Chwile oderwane, oprac. P. Kłoczowski, Gdańsk 2007, s. 363. Tam, gdzie to możliwe, będę korzystał z tekstów Jeleńskiego zebranych i wydanych w formach książkowych, w których uwspółcześniono i poprawiono wszelkie zapisy. Będą to przede wszystkim: Zbiegi okoliczności (O przeczytanym i przeżytym przez 30 lat), wybrał i zredagował P. Kłoczowski, t. 1-2, Kraków: Wydawn. Kos, 
Zatem początek ewidentnej fascynacji. Zauroczenie i wreszcie możliwość utożsamienia z czymś, z kimś zewnętrznym, ale odpowiadającym temu, co wewnątrz, temu tuż obok. Ten „klucz” ukryty w Ferdydurke okazał się dla Jeleńskiego narzędziem uniwersalnym, otwierającym drzwi do rzeczywistości takiej, jaka jest, a nie jaką wszyscy wokół próbują sztucznie wytworzyć. Mówiąc najprościej: był to klucz do prawdy. Okazało się, że „,niedojrzali, niedopieczeni, śmieszni, skompromitowani jesteśmy bliżsi rzeczywistości niż wysublimowani i dojrzali"2. Jak i dlaczego doszło do tego utożsamienia, dlaczego Jeleński odnalazł w ferdydurkowskim świecie przedstawionym swój świat, po części wyjaśnił już sam w przytoczonym cytacie. Aby jednak uchwycić w pełni podstawy tej identyfikacji, warto nakreślić w tym miejscu drobny rys dziecięcych i młodzieńczych lat Jeleńskiego, które miały wielki wpływ na jego życie dorosłe.

Urodził się w Warszawie 2 stycznia 1922 roku (w domu przy ul. Wiejskiej 13) jako syn Konstantego Jeleńskiego i Teresy (Reny) ze Skarżyńskich ${ }^{3}$. Chrzczony był w kościele świętego Aleksandra na placu Trzech Krzyży. Obie rodziny wywodziły się z zamożnego ziemiaństwa, istniały między nimi jednak pewne różnice. Rodzina ojca, o ko-

1981 (nazwane dalej ZO I i ZO II); zbiór wydany pod tym samym tytułem (choć przynoszący trochę inny wybór) w paryskim Instytucie Literackim rok później (dalej ZOP); Szkice, wybór W. Karpiński, Kraków 1990 (dalej S); Chwile oderwane, [wybrał i oprac., P. Kłoczowski], Gdańsk 2007 (dalej CO). Przy oznaczeniu zbioru podaję lokalizujące cytat numery stron.

${ }^{2}$ K. A. Jeleński, „Ferdydurke”..., s. 362. Fenomen Ferdydurke, który urzekł Jeleńskiego, najtrafniej zdaje się opisywać w przedwojennej recenzji Bruno Schulz: „gdy Freud, odkrywszy dziedzinę podświadomości, uczynił z niej curiosum psychologiczne, wyspę izolowaną, której niezrozumiałe manifestacje i odrębną, paradoksalną logikę ukazał wyraźnie odgraniczone, niejako za kratami patologii, odseparowane od tła normalnych przebiegów, Gombrowicz skierował swój wziernik właśnie na te rzekomo normalne i dojrzałe procesy i wykazał, że ich legalność i prawidłowość jest złudzeniem optycznym naszej świadomości, która sama, będąc produktem pewnej tresury akceptuje tylko treści sobie adekwatne, nie notyfikuje zaś żywiołu niedojrzałości, otaczającego swym zalewem nikłą lagunę oficjalnych treści. [...] Freud pokazał mały wycinek tego podziemnego świata dostępny metodom psychologa, którymi zneutralizował destrukcyjne działanie śmieszności i nonsensu. Pozostaje on w gruncie rzeczy na płaszczyźnie powagi naukowej. Ale generalny atak na tę dziedzinę mógł udać się tylko przez całkowite zwinięcie i opuszczenie pozycji powagi, przez otwarcie frontu dla żywiołu śmiechu, dla bezgranicznej inwazji komizmu. Okazuje się, że samej powadze naukowej, w samej dostojnej pozie badacza leżał najpoważniejszy szkopuł nie pozwalający na gruntowną dekonspirację mechanizmu myślenia. Oficjalność i obłuda wypłoszone z pozycji zdemaskowanej chroniły się w powagę postawy badawczej. Była to gra w ciuciubabkę, którą zlikwidował Gombrowicz, przełamując z niesłychaną śmiałością bariery powagi. Udało mu się przerobić narzędzie destrukcji na organ konstruktywny”; B. Schulz, ,Ferdydurke”, Skamander 1938 z. 96-98, s. 184.

${ }^{3}$ Biologicznym ojcem Jeleńskiego był hrabia Carlo Sforza (1872-1952), włoski minister spraw zagranicznych w latach 1920-1921 i 1947-1952. O relacjach Sforzy z Reną Jeleńską zob.: K. A. Jeleński, L. Zeno, Listowna opowieść, tłum. St. Kasprzysiak, Zeszyty Literackie $2004 \mathrm{nr}$ 86, s. 81-96. W korespondencji tej Jeleński wspomina także o Konstantym Jeleńskim seniorze, którego bardzo kochał i szanował, mając jednak świadomość swoistej niekonwencjonalności jego (tj. ojca) relacji z matką. Pisał o nich: „Sądzę, że kochał matkę prawdziwie (powiedział mi kiedyś, na kilka lat przed śmiercią, że wielką miłość przeżył tylko dwa razy w życiu — do tancerza rosyjskiego z baletu Diagilewa w Paryżu [...] i do mojej matki...). Jego zmysłowość nie była więc tak prosta i chociaż miał także wiele kochanek wśród kobiet z różnych sfer w stolicach, gdzie był en poste, w sprawach seksu, co mi również powiedział, czuł się w swoim żywiole tylko w głośnych burdelach... takich jak Chabanais czy Sphinx. Matka mi mówiła, że jej małżeństwo nie zostało «skonsumowane» co najmniej rok po «ceremonii ślubnej», wiem też, że ojciec zawsze respektował wolność matki i nigdy z zazdrości niczego jej nie wyrzucał (co byłoby doprawdy niewłaściwe)”. Matce bowiem zdarzały się także „poufałości” z pięknymi kobietami. 
rzeniach litewsko-białoruskich, osiadła na ziemiach Wielkiego Księstwa Litewskiego, reprezentowała opcję konserwatywną ${ }^{4}$, podczas gdy ta ze strony matki, „,mazowiecka”, była w większości liberalna, antyendecka, i to ona właśnie żywo interesowała się szeroko rozumianymi sprawami artystycznymi.

Dziecięce lata Jeleński wspomina raczej gorzko. Do trzynastego roku życia wychowywała go babka, Maria Magdalena (Maneta) z Czarnowskich Skarżyńska (siostra antropologa Stefana Czarnowskiego). Dyplomatyczne obowiązki ojca, pracownika przedwojennego Ministerstwa Spraw Zagranicznych, który stale zmieniał placówki, powodowały, że z rodzicami jako dziecko widywał się głównie podczas świąt i wakacji. Częste wyjazdy i znany w rodzinie alkoholizm ojca były wystarczającymi argumentami za powierzeniem wychowania Konstantego matce Reny. Babcia przejęła go, gdy miał sześć tygodni. Rena zaś wróciła do Rzymu, gdzie mąż jej był wówczas pierwszym sekretarzem poselstwa polskiego. Do czwartego roku życia chował się głównie w rodzinnych majątkach w Kroczewie i Rybienku, gdzie bardzo o niego dbano, zapewniając mu stałe towarzystwo guwernantek od kilku języków.

Charyzmatyczna matka Jeleńskiego była znaną postacią międzywojnia. Do przyjaciół rodziców należeli m.in. sanacyjni pułkownicy (Józef Beck, Bolesław Wieniawa-Długoszowski), poeci Skamandra, Karol Szymanowski (daleko spokrewniony z Reną Jeleńską), Paweł Kochański, Helena Boguszewska i Jerzy Kornacki, Artur Rubinstein czy Stanisław Ignacy Witkiewicz, który namalował nawet dwa portrety małego Konstantego.

$\mathrm{Z}$ czasem coraz częściej Jeleński przebywał z rodzicami na europejskich placówkach: w Madrycie, Bukareszcie czy Wiedniu. Ten brak „stałości” w życiu małego jeszcze Konstantego nie podobał się Manecie, która w roku 1930 znów wzięła go do siebie. Mieszkając u babci, Jeleński uczył się w Gimnazjum im. Stefana Batorego (w klasie z Krzysztofem Baczyńskim). Mum, jak sam nazywał ukochaną babcię, zmarła w roku 1935. Jej trwająca rok choroba przyniosła odwrócenie obowiązków: to Kocik, jako trzynastolatek, opiekował się nią aż do jej śmierci. Był to dla niego okres przyspieszonego dorastania. Po jej odejściu przebywał rok w internacie oo. dominikanów w szwajcarskim Ouchy, a następnie rozpoczął naukę w elitarnym liceum z internatem im. Sułkowskich w Rydzynie ${ }^{5}$, w którym to, jeszcze przed wybuchem wojny, w 1939 roku zdał maturę.

Okupowaną Warszawę Jeleński opuścił wraz z matką pod koniec roku 1939 dzięki pomocy włoskich przyjaciół rodziny ${ }^{6}$. (Jak się później okazało, do Polski już nigdy nie wrócił.) Śladem ojca udali się do Włoch, gdzie Konstanty został osobistym sekretarzem ambasadora gen. Bolesława Wieniawy-Długoszowskiego. Po trzech miesiącach pobytu w Rzymie, wbrew woli matki, Konstanty wstąpił do Wojska Polskiego we Francji, gdzie przydzielono go do artylerii przeciwlotniczej w Saint-Nazaire. Po klęsce Francji

${ }^{4}$ Opis rodziny ojca odnajdziemy we wspomnieniach ciotki Jeleńskiego — Janiny z Puttkamerów Żółtowskiej, zatytułowanych Inne czasy, inni ludzie (Londyn 1959), do których jeszcze wrócimy.

5 ,[...] liceum z internatem wzorowanym na angielskim Eton, gdzie czesne wynosiło trzy tysiące rocznie i uczniami byli chłopcy z najlepszych i najbogatszych domów, między innymi Józio Zwisłocki, wnuk prezydenta Mościckiego, mały Papée, syn ambasadora polskiego przy Watykanie, i w ogóle sami Lubomirscy, Platerowie i tym podobni”; J. Siedlecka, Kocik, [w:] tejże, Wypominki, Warszawa 2001, s. 156.

${ }^{6}$ Jeleński miał usłyszeć wcześniej od ojca: „Nie wiem, jakie są wasze plany, ale ja stąd wyjeżdżam”; podaję za: A. Zagajewski, O Konstantym Jeleńskim, Zeszyty Literackie 1987 nr 19, s. 125 . 
został ewakuowany do Anglii: przez krótki okres był tłumaczem w kwaterze polowej gen. Władysława Sikorskiego w posiadłości Gask House w hrabstwie Fyfe w Szkocji, następnie zaś - po ukończeniu podchorążówki artylerii — przydzielony został do 1. Pułku Artylerii Motorowej. Do Londynu dotarli wówczas także jego rodzice. (Rena Jeleńska przetłumaczyła w tym czasie Folwark zwierzęcy Orwella ${ }^{7}$.) Dzięki uzyskanemu w 1941 stypendium British Council mógł w latach 1941-1943 studiować ekonomię i nauki polityczne na uniwersytecie w Saint Andrews w Szkocji (gdzie uzyskał stopień Master of Arts), a następnie, dzięki kolejnemu rocznemu stypendium, kontynuował studia w Pembroke College w Oxfordzie, tym razem w zakresie historii nowożytnej. Przyjaciel, Auberon Herbert, wprowadził go wówczas do środowiska angielskiej arystokracji.

Po studiach, w 1944, Jeleński wrócił do swego pułku, by niedługo później, wraz z 1. Dywizją Pancerną, wylądować w Normandii. Kampanię Normandia-Belgia-Holandia, jak sam wspomina, odbył w czołgu, jako obserwator artyleryjski. Jego zasługi przyniosły awans na porucznika, został odznaczony także Krzyżem Walecznych, Medalem Wojska i Srebrnym Krzyżem Zasługi. Czasów tych, a w szczególności zasług, nigdy publicznie nie przywoływał. Jeszcze w Holandii przydzielono go do redakcji „Dziennika Żołnierza I Dywizji Pancernej”, której członkiem był od końca 1944 do 1946, kiedy został jego redaktorem naczelnym. Współpracował także z miesięcznikiem 1. Dywizji „Salamandra”, gdzie opublikował swój pierwszy tekst — recenzję tomu wierszy Miłosza Ocalenie z roku $1945^{8}$.

\footnotetext{
${ }^{7}$ Pierwsze wydanie tłumaczenia miało miejsce w Londynie w roku 1947 jako Zwierzęcy folwark. W 1956 roku ukazało się także wydanie Folwarku zwierzęcego w przekładzie Jeleńskiej wydane przez Wolną Europę. O tym wydaniu Jeleński pisał do Iwaszkiewicza: ,[Mama] Jest bardzo niezadowolona, bo bez jej pozwolenia Free Europe pod jej nazwiskiem wydało tłumaczenie Animal Farm Orwella na zrzuty do Polski. Tłumaczenie, które zrobiła w r. 1945 w Londynie i wydała w Światpolu. Ja też jestem wściekły. Co to za sens teraz zrzucać Orwella do Polski? A przytem Mama chciała może na przyszłą wiosnę pojechać z wizytą do Polski, i zaprosiła właśnie do Rzymu ciocię Magdzię Skarżyńską. Dowiaduję się w dodatku, że radio Kraj mówiło o tym i to w związku ze mną - że nie wiedzą czy to matka, czy ciotka p. Jeleńskiego, niezależnego pisarza z «Kultury» za ciężkie dolary tłumaczy Orwella dla Free Europe na zrzuty. Biedna Mama... widziała z tego 30 funtów dwanaście lat temu...”; J. Iwaszkiewicz, T. Jeleńska, K. A. Jeleński, Korespondencja, oprac. R. Romaniuk, Warszawa 2008, s. 27. Pierwsze wydanie krajowe tego tłumaczenia ukazało się w 1985 r. w podziemnej Oficynie Literackiej, z ilustracjami Jana Lebensteina. Jeleńska przełożyła także kilka ważkich esejów Orwella drukowanych w „Kulturze” w końcu lat 40. Była także autorką (pod pseud. Renée Bayard) francuskiego tłumaczenia Kluczy Marii Kuncewiczowej (Les clefs, Paris 1946) oraz powieści Heleny Boguszewskiej Całe życie Sabiny — rękopis tego tłumaczenia zaginął jednak podczas wojny. Na włoski przełożyła wiersze Aleksandra Wata Arytmetyka i Przed weimarskim autoportretem Durera; zob.: A. Wat, Aritmetica, Davanti dell'autoritratto di Dürer a Weimar, Tempo Presente $1960 \mathrm{nr}$ 11, s. 767-769. Na polski przetłumaczyła zaś, także wydane anonimowo, wspomnienia Zoë Zajdlerowej Nazywam się miljon (Londyn 1942) i Wspomnienia rodzinne Eleny Croce (Paryż 1966, wyd. krajowe: Lublin 1997). Była przy tym autorką rozdziału o Józefie Piłsudskim do książki Carlo Sforzy Les batisseurs de l'Europe moderne (Paris [1931]). Tłumaczyła także utwory Curzio Malapartego i Jana Capa.

${ }^{8}$ [K. A. Jeleński] KAJ, Klasyk na wygnaniu, Salamandra 1946 nr 1, s. 50-53. W rozmowie o Miłoszu z Renatą Gorczyńską Jeleński wspomina: „Proszę sobie wyobrazić, że o Miłoszu nigdy przed wojną nie słyszałem. Zetknąłem się z jego poezją, kiedy przeczytałem Ocalenie w 1946 roku. I muszę powiedzieć, że pierwszym tekstem literackim, jaki w ogóle w życiu napisałem, był mój artykuł o tym tomie wierszy, ogłoszony w «Salamandrze», miesięczniku Pierwszej Dywizji Pancernej. Świadczy to o liberalizmie tej formacji, w przeciwieństwie do Drugiego
} 
Po wojnie, Konstanty wylądował w Rzymie na polskiej placówce wojskowej przy Ambasadzie Brytyjskiej, skupiającej zdemobilizowanych żołnierzy 2. Korpusu z Włoch' W 1947, po demobilizacji, rozpoczął pracę w Międzynarodowej Organizacji do Spraw Uchodźców (International Refugee Organization) w Neapolu, a potem, w latach 19481951, pracował w wydziale ekonomicznym rzymskiej agendy ONZ do spraw żywności i rolnictwa (Food and Agricultural Organization of the United Nations). Był już wówczas stałym bywalcem europejskich salonów, a - za sprawą Jerzego Giedroycia i Józefa Czapskiego - wszedł wkrótce także w krąg intelektualistów Kongresu Wolności Kultury (Congrés pour la Liberté de la Culture) — instytucji założonej na konferencji w Berlinie, wspierającej intelektualistów zza żelaznej kurtyny. W pierwszym swym liście do Jeleńskiego z roku 1950 Giedroyc proponował mu stanowisko korespondenta „Kultury” w Berlinie, rysując jednocześnie perspektywę pracy w sekretariacie generalnym Kongresu. Sytuacja Jeleńskiego we Włoszech była jednak na tyle bezpieczna finansowo, że pod pretekstem odpowiedzialności za rodzinę (utrzymywał oboje rodziców) — taktownie odmawiał stałej współpracy.

Zwrotem w tej sytuacji zdaje się być spotkanie przyszłej życiowej partnerki Leonor Fini, od 1952 roku mieszkającej w Paryżu, charyzmatycznej włoskiej malarki, czternaście lat starszej od Jeleńskiego. Ona właśnie okazała się powodem jego przeprowadzki z Rzymu do Paryża ${ }^{10}$, w którym to, dzięki pomocy wspomnianych przyjaciół z „Kultury”, otrzymał w roku 1952 stanowisko w Kongresie, jako kierownik sekcji wschodnioeuropejskiej oraz pracę w redakcji miesięcznika „Preuves” — organu Kongresu. Giedroyc powierzył Jeleńskiemu rolę człowieka „Kultury” w Kongresie, choć jak się z czasem okazało - ich koncepcje często dość znacznie się różniły.

Rok 1952 w biografii Jeleńskiego to nie tylko moment, kiedy przeprowadza się na dobre do Paryża i rozpoczyna stałą współpracę z „Kulturą” — jest to także rok, w którym (już jako trzydziestoletni mężczyzna) nawiązuje korespondencyjny kontakt z Gombrowiczem ${ }^{11}$. Wkrótce potem szybko rusza menadżerska machina, jaką okazał się dla Gombrowicza Jeleński. Pierwszy artykuł o nim ogłosił w „Preuves” w roku 1953 (nr 34). Po młodzieńczej fascynacji Ferdydurke zachwyt Jeleńskiego wzbudził Trans-Atlantyk. Z przetłumaczonymi przez siebie fragmentami obu książek chodził gdzie tylko się dało, chcąc jak najszybciej przedstawić francuskiej publiczności odkrytego przez siebie geniusza. Odrzucił je jednak Mascol u Gallimarda, u Calmann-Levy’ego też nie przyjęli. Zainteresował się natomiast François Bondy, redaktor na-

Korpusu, bo na przykład w «Wiadomościach» nie było możliwe napisać dobrze o Miłoszu, nazywanym wtedy «pisarzem reżimowym». Ja natomiast napisałem entuzjastyczną recenzję"; R. Gorczyńska, Portrety paryskie, Kraków 1999, s. 237.

9 We wspomnieniu po śmierci Zygmunta Hertza Jeleński pisze: „Zygmuntów poznałem w roku 1946 w Rzymie, gdzie ściągnął mnie z Pierwszej Dywizji Pancernej Emeryk Czapski, szef polskiej placówki wojskowej przy Ambasadzie Brytyjskiej, zajmującej się emigracją z Włoch żołnierzy Drugiego Korpusu, żonatych z Włoszkami, którym odmówiono prawa osiedlenia się w Wielkiej Brytanii”; K. A. Jeleński, Zygmunt Hertz, mój przyjaciel, [w:] CO, s. 107.

10 „Kiedy Kot zjechał definitywnie do Paryża i zamieszkał z Leonor na rue Payenne (po lecie 1952 roku spędzonym w pobliżu Rzymu na małej plaży, której nazwa wyleciała mi z głowy), był ciągle w owym stanie zauroczenia miłosnego, oddania na śmierć i życie [...]"; B. Minoret, Z listów do Piotra Kłoczowskiego, tłum. J. Lisowski, Zeszyty Literackie 1998 nr 61, s. 49.

${ }^{11}$ Korespondencja była długo ich jedynym kontaktem, przez wiele lat w ogóle się nie widzieli — do roku 1963. Gombrowicz miał wtedy powiedzieć: „No, więc jestem. Proszę cię, tylko bez żadnej wylewności. Wchodzisz i witamy się, jakbyśmy się wczoraj rozstali”; K. A. Jeleński, O Gombrowiczu, [w:] CO, s. 473. 
czelny „Preuves”, i tak wyszedł numer specjalny tego pisma, poświęcony Gombrowiczowi, po którym na wydanie jego dzieła zdecydował się Maurice Nadeau. Potem wszystko poszło już dość płynnie: kolejne zagraniczne wydania, wzmianki w europejskiej prasie, kolejne tłumaczenia, stypendium do Berlina Zachodniego dla Gombrowicza w $1963^{12}$, stypendium Fundacji Forda, poświęcony Gombrowiczowi ogromny tom z cyklu „Cahiers de l'Herne” — we wszystkim zasługa Admirała Jeleńskiego, jak nazywał go często autor Pornografii w listach do Jerzego Giedroycia ${ }^{13}$.

Śledząc korespondencję Gombrowicza z Jeleńskim, dotyczącą głównie spraw wydawniczych, edytorskich, translatorskich, honorariów oraz tych wszystkich, o które dba współczesny impressario, nie można dziwić się tytułowi, jakim opatrzyli ją jej wydawcy - Walka o sławę ${ }^{14}$. Gombrowicz odkrywa w listach momentami swoje desperackie oblicze ${ }^{15}$, za wszelką cenę chce wydawać swoje dzieła i - czego systematycznie pilnował w Dzienniku — mieć nad ich interpretacją pełną kontrolę. W tej mierze był bardzo nieufny wobec czytelnika, nie miał też tej swobody, która pozwalałaby mu na ignorowanie najróżniejszych głosów krytyki. W Dzienniku notował:

Czy przeceniam sam siebie? Naprawdę, wolałbym odstąpić komu innemu niewdzięczną i ryzykowną rolę komentatora własnych, wątpliwych osiągnięć, ale w tym sęk, że w warunkach, w jakich się znajduję, nikt tego za mnie nie wykona. Nawet mój nieoszacowany poplecznik Jeleński ${ }^{16}$.

\footnotetext{
${ }^{12}$ Warto przytoczyć „ciekawą” opinię na ten temat anonimowego „Z” z warszawskiej „Kultury”: „Ilekroć ktoś z Polski opluje własne państwo, porzuci kraj, okaże nielojalność wobec elementarnych interesów narodu — może być pewien, że «Wolna Europa» weźmie go w obronę. Tak stało się również z... Witoldem Gombrowiczem. Jego apologię przez monachijskie radio wygłosił ostatnio Konstanty Jeleński. [...] Próbował uczynić z Gombrowicza propagatora polskiej kultury w Niemczech. Ale fakty mówią co innego. [...] Co do Gombrowicza - należy powiedzieć, że jego obecność w Berlinie Zachodnim nie ma tak niewinnego charakteru jak zapewnia Konstanty Jeleński. «Fundacja Forda ustanowiła kilkanaście rocznych stypendiów dla pisarzy, artystów o rozgłosie światowym, sądząc, że sam fakt ich pobytu w Berlinie Zachodnim będzie przeciwdziałał prowincjonalizmowi, któremu chce się zapobiec. W ten sposób Gombrowicz znalazł się w Berlinie Zachodnim». Kłamstwo. Fundacja Forda i senat zachodnioberliński zorganizował całą tę akcję pod hasłem integralnej łączności Berlina Zachodniego i NRF. Na rzecz tej właśnie łączności mają demonstrować zaproszeni i (opłaceni) pisarze. Wśród nich musiałby się znaleźć pisarz polski, przedstawiciel kultury, której hitleryzm zadał straty najcięższe. Znalazł się taki pisarz: Gombrowicz. [...] Na ten właśnie chorobliwy kompleks niższości złowił Gombrowicza międzynarodowy, agenturalny cwaniak, działający na pograniczu kultury i polityki. Wmówił mu, że dopiero tu, w Berlinie Zachodnim wyjdzie $\mathrm{z}$ «kredensu», $\mathrm{z}$ «przedpokoju», że dopiero tu zabłyśnie jako pisarz europejski, ba, światowy. Smutna sprawa - jeżeli chodzi o Gombrowicza. Brudna sprawa, jeżeli idzie o Jeleńskiego”; „Z”, Postuchajcie Jeleńskiego, Kultura (Warszawa) $1963 \mathrm{nr}$ 21, s. 12.

${ }^{13}$ Zob.: J. Giedroyc, W. Gombrowicz, Listy 1950-1969, oprac. A. St. Kowalczyk, Warszawa 1993, passim

${ }^{14}$ Wydanie to zawiera także korespondencję Gombrowicza z innymi pisarzami; zob.: Gombrowicz - walka o stawę. Korespondencja, układ i przedmowy J. Jarzębski, t. 1-2, Kraków 1996-1998.

${ }^{15}$ Czesław Miłosz notował: ,ja sam, czytając korespondencję pomiędzy Kotem Jeleńskim i Gombrowiczem o lansowaniu Ferdydurke w Europie, powiedziałem sobie, że spaliłbym się ze wstydu, gdybym tak musiał o swoją sławę zabiegać. Wydałoby mi się to czymś poniżej mojej godności"; Cz. Miłosz, Rok myśliwego, Kraków 2001, s. 306.

${ }^{16}$ W. Gombrowicz, Dziennik, t. 1: 1953-1956, Kraków 2004, s. 147.
} 
Jego dzieło nie mogło być zrozumiane inaczej, niż nakazywał głos autorski, miało bardzo konkretny przekaz, stąd był Gombrowicz bardzo stanowczy i nie unikał publicznej polemiki, dotykającej jego twórczości, co wielu zresztą uważało za żenujące. On chciał jednak postawić na swoim, mieć w kwestii swojego dzieła — być może słusznie - zdanie ostateczne. Swoboda interpretacyjna była dla niego chyba nie do przełknięcia. Uciekając od formy, narzucał swoją:

Głód uznania, wola narzucenia światu swego dzieła była dla mnie bardziej zrozumiała u Gombrowicza. Powodem bardziej ,zewnętrznym” była w moich oczach rola „mesjanistyczna”, jaką przypisywał sobie Witold. Głębszym powodem natomiast była niemożność (czy nieumiejętność) ,życia”, jaka cechowała Gombra. On, czciciel „niższości”, cielesności, wróg abstrakcji i „,kultury” był człowiekiem naprawdę aliéné, pozbawionym (jak sam pisał) „daru miłości”, niezdolnym właściwie do żywego stosunku z ludźmi, ze zwierzętami, z naturą. Witold ,żył” tylko pisząc i rozgłos był chyba dla niego potwierdzeniem tego istnienia ${ }^{17}$.

Gombrowicz poświęcił się swemu dziełu totalnie, pozwolił mu niejako na zdeterminowanie życia, co miało oczywiście swe konsekwencje. Bardzo „serdeczne zainteresowanie ludźmi”, charakterystyczne dla Jeleńskiego, było przeciwieństwem usposobienia Gombrowicza. Jego egocentryzm, dla wielu rażący, nie był jednak dla Kota (jak Jeleńskiego nazywali przyjaciele) przeszkodą. Był mu w pełni oddany, zupełnie bezinteresownie - owa bezinteresowność to też cecha obca Gombrowiczowi, który liczył się przede wszystkim ze sobą i początkowo nie dowierzał chyba także w ideowość Jeleńskiego, któremu nie zależało na wynagrodzeniu. W 1953 roku, a więc po jeszcze stosunkowo krótkiej znajomości z Jeleńskim (w dodatku jedynie listownej), w korespondencji z Jerzym Giedroyciem, Gombrowicz delikatnie podpytywał, jak uregulować z Kotem kwestie honorariów za jego poświęcenie. Dla Giedroycia, człowieka twardo przecież stąpającego po ziemi, sprawa była jasna — odpowiadał:

Jeleński jest wielkim Pana entuzjastą i bardzo go cenię i jako talent, i charakter. Ma dużo stosunków, ale nie myślę, by go tzw. „,interesy” obchodziły. Lepiej więc niech mu Pan nie proponuje podziału zysków. Zrobi i bez tego wszystko, co będzie tylko moż$\mathrm{na}^{18}$.

Sprawa wynagrodzenia powracała w korespondencji z Redaktorem. Wysiłki Jeleńskiego mogły rzeczywiście być dla Gombrowicza krępujące, nie przeszkadzało mu to jednak w stałym przypominaniu o kolejnych akcjach, mających popularyzować jego twórczość. Sporadycznie pojawiała się refleksja o ewentualnej podzięce:

On w istocie z niesłychanym zapałem Ferdy lansował i jemu prawie wszystko zawdzięczam. W tej chwili jestem jeszcze nędzarz, ale to przecież się skończy, gdy te umowy zaczną funkcjonować. Nie znam jego sytuacji finansowej - czy raczej odstąpić mu jakiś \% w gotówce, tytułem zwrotu kosztów i czasu, czy też raczej jakiś prezencik. Ale jaki? Za ile? Tutaj zupełnie inna sytuacja ekonomiczna niż u Was, więc mnie trudno się zorientować. $Z$ drugiej strony obawiam się, żeby go nie urazić jakąś niewłaściwą propozycją. W każdym razie obszernie uwiecznię go w Dzienniku ${ }^{19}$.

\footnotetext{
${ }^{17}$ Z listu K. A. Jeleńskiego do Cz. Miłosza z 19 marca 1977, Zeszyty Literackie 1995 nr 50,

${ }^{18}$ Z listu J. Giedroycia do W. Gombrowicza z 27 października 1953; zob.: J. Giedroyc, W. Gombrowicz, Listy 1950-1969, s. 90.

${ }^{19}$ Tamże, s. 265 (list z 6 kwietnia 1959).
} s. $80-81$. 
„Obszerne uwiecznienie” jest oczywiście pojęciem względnym, bacząc jednak na objętość Dziennika można chyba powiedzieć, że miejsce Jeleńskiego nie jest w nim zaznaczone w sposób szczególny, tj. odpowiadający jego zasługom ${ }^{20}$. Robił dla Gombrowicza wszystko, co mógł, nie licząc na wiele. Akcja ta miała charakter zdecydowanie jednostronny — abstrahując oczywiście od korzyści (wymiany) intelektualnej, jaką mimowolnie zafundował mu Gombrowicz. Stąd pozostaje nadal w powszechnej opinii znany przede wszystkim jako popularyzator jego dzieła.

Problem z autorem Ferdydurke, który we wszelkich kontaktach z ludźmi sprawiał wrażenie zawsze skupionego jedynie na sobie, był niewątpliwy.

Jest Gombrowicz. Góra samouwielbienia, chwalby, gadaniny na swój temat, na tematy swojej produkcji, swojej dystynkcji. Kpi czy o drogę pyta. Jeśli kpi - można wytrzymać - jeśli serio, to facet jest chory na głowę. Wyobrażam sobie wielkiego, ogromnego Gombrowicza w gaciach, w hotelu, w pokoiku w kwiatki i wtedy na pewno nie ma tej pewności siebie, że jest taki wspaniały. Na pewno myśli, że jest stary, że skarpetki dziurawe, że wszystko do chrzanu. Tak do rannej kawy w hotelu — potem kładziemy na siebie mundur i dawaj s naczała - że Nobel, że geniusz, że Mickiewicz grafoman, że tylko on jedyny, pępek i ośrodek świata. Ale jak idzie ulicą i żadna dziewczyna się za nim nie obejrzy, żaden chłopak nie łypnie - to wtedy gorzej. Kot nad nim cmoka jak tylko może $\mathrm{e}^{21}$.

Tak w liście do Czesława Miłosza komentował pobyt Gombrowicza w Maisons-Laffitte Zygmunt Hertz. I nie da się ukryć, że Jeleński „,cmokał jak tylko mógł”, ale robił to w pełni świadomie i z pełnym przekonaniem:

[...] rolę grała tu waga, jaką dla mnie miało Ferdydurke, kiedy miałem 15 lat, moje przekonanie, że „rozumiem” Gombrowicza lepiej od innych i że mogę to czytelnikom przekazać (element astuce, dojścia głębiej poprzez concetto) ${ }^{22}$.

Był bez dwóch zdań jego najwierniejszym i najbardziej lojalnym czytelnikiem, najsubtelniejszym krytykiem ${ }^{23}$. Rozumieli się doskonale i, jak obaj wyczuwali, nie mogło być to porozumienie na gruncie czysto literackim, artystycznym: „Tu nie wystarcza sama tylko chłonność, chwytność, takie współbrzmienie może się wydarzyć tylko na gruncie

\footnotetext{
${ }^{20}$ Wzmianki o Jeleńskim w Dzienniku mają ponadto często charakter dość dwuznaczny, np.: „Muszę dbać o Jeleńskiego, który mnie rozumie, który się wybija, któremu pozycja w piśmiennictwie polskim i francuskim organizuje się sama”. Albo: „Ale Jeleński! Nie wiem, jak to tam było, ale bez «Kultury» nie wyskoczyłby na jedynego publicystę polskiego naprawdę wprowadzonego w Europę, nie przeniknąłby do poważnej elity francuskiej”; cyt. kolejno za: W. Gombrowicz, Dziennik, t. 1: 1953-1956, s. 199 i t. 3: 1961-1969, s. 209.

${ }^{21}$ Z listu Z. Hertza do Cz. Miłosza z 11 maja 1963; zob.: Z. Hertz, Listy do Czestawa Mitosza 1952-1979, oprac. R. Gorczyńska, Paryż 1992, s. 152.

${ }^{22}$ Z listu K. A. Jeleńskiego do Cz. Miłosza z 19 marca 1977, Zeszyty Literackie 1995 nr 50, s. 81 .

${ }^{23}$ Z listu Z. Hertza do Cz. Miłosza z 28 sierpnia 1975: „Kot szaleje — robi psychoanalizę Gombrowicza. Mam pomieszane uczucia — sens tego taki, że facet był nieprzyjemny w pożyciu, «Gombrowicz żywy» — puszący się, łasy na komplementy, wmawiający że jest geniusz, snobiszcze - i król niezrozumialstwa. A Kot go rozbiera do gaci. Zabawny jest ten rozbiór jego produkcji i dogrzebywanie się do kompleksów, co autor miał na myśli, etc. Wyciągnął go Kot na szerokie wody, nadał mu żagle, facet był dobrym nawigatorem, a teraz Kot-kamieniarz chce mu postawić trwały pomnik. Bardzo dobrze, szczególnie że pójdzie «międzynarodowo» [...] Niech mu będzie! Muszę przyznać, że K[ot] zna na pamięć produkcję Gombr[owicza] — gdyby miał temacik zadany z niego — piątka”; Z. Hertz, Listy do Czestawa Miłosza 1952-1979, s. 427.
} 
pokrewieństwa natur"24 - notował w Dzienniku autor Trans-Atlantyku. Jeleński czuł podobnie: „Myślę, że pomiędzy Witoldem a mną istniała jakaś wspólnota psychiczna [...] Wrodzona wspólnota psychiczna wyhodowana w tej samej kulturze, in vitro" ${ }^{\not 2}$. Owa wspólnota nie oznaczała jednak, jak się zdaje, przyjaźni, a w każdym razie nie w potocznym tego słowa rozumieniu. Osobiste kontakty Jeleńskiego ze swoim literackim guru regulowała konkretna konwencja. Kłamstwem par exellence była dla Gombrowicza poza naturalności i spontaniczności, w związku z czym dotrzeć należało do określonego stylu, który byłby zrozumiały i nie budził podejrzeń. W tej konkretnej stylizacji Jeleński zajął oczywiście pozycję niższą, ,panem” był Gombrowicz. Hierarchia pasowała jednak obu. To, co być może pociągało Jeleńskiego w autorze Kosmosu, to świadomość swojej wartości. Domagał się on przecież w Dzienniku słowa „odświętnego" dla siebie, pospolity dyskurs był dla niego obrazą. Całe swoje życie postawił na dzieło, które go stwarzało. Stąd artystyczne widzenie musiało być u niego w pełni oryginalne, świeże, nie naznaczone żadnym innym, musiało być „z pierwszej ręki” na inną literaturę, jak mówi Jeleński, nie pozwoliłby Gombrowiczowi chociażby jego narcyzm. Nie adaptował żadnej myśli na swój użytek — filtrował je przez własne ,ja", naznaczał sobą. Dzieła, które na to nie pozwalały zupełnie go nie interesowały - nie przyjmował dzieł ostatecznych, które de facto sam tworzył. Jeleński pisze: „Paradoksalnie można by powiedzieć, że Gombrowicza nudziłoby Ferdydurke, gdyby było napisane przez kogo innego"26.

Słabostki Gombrowicza Jeleński znał chyba jak mało kto, niewykluczone też, że w swych tekstach czy codziennych rozmowach, to właśnie on mu je uświadamiał. I choć Gombrowicz znany był przede wszystkim ze zdolności samorozpoznania (był swoim idealnym krytykiem i komentatorem), to na tej drodze pomagał mu bez wątpienia także Jeleński.

Pisząc w roku 1985 o Ferdydurke, Jeleński dotyka spraw fundamentalnych w twórczości Gombrowicza, lecz (po tylu latach) robi to w sposób wyjątkowo świeży. Podkreśla przede wszystkim wagę pojęcia „,formy”, którym Gombrowicz nazwał ten powszedni, wszechobecny ucisk, tak doskwierający Jeleńskiemu na co dzień. Zrozumiałym okazało się, czym ta presja jest w istocie. Jest niewolą, i co istotne - niewolą, od której nie ma ucieczki. Uświadomienie czytelnikowi takiego właśnie stanu rzeczy, z którego należy zdać sobie sprawę i który należy zaakceptować (bo innego wyjścia nie ma), było celem Gombrowicza - co trafnie podkreśla Jeleński. Zauważa także rzecz bardzo istotną, nie zawsze w literaturze przedmiotu wychwytywaną. Zabawa $\mathrm{z}$ formą ujawniła się u Gombrowicza także na gruncie form literackich, których właśnie parodią były w zamierzeniu jego utwory. I tak:

Ferydurke wzorowana jest na francuskim conte philolosophique w rodzaju Kandyda Woltera. Trans-Atlantyk odwraca dosłownie do góry nogami Pana Tadeusza Mickiewicza największy poemat literatury polskiej. Pornografia nawiązuje do naiwnej dziewiętnastowiecznej polskiej ,powieści wiejskiej”. Kosmos jest napisany w konwencji kryminalnego romansu. Trzy jego sztuki: Iwona, Ślub, Historia parodiują Szekspira, a ostatnia — Operetka — jest hołdem złożonym „,boskiemu idiotyzmowi” tego genre'u. ${ }^{27}$

Jeleńskiego urzekło w pierwszej kolejności jawne odkrycie elementów sztucznej rzeczywistości. Gombrowicz dokonywał tego poprzez penetrację ludzkiej świadomo-

\footnotetext{
${ }^{24}$ W. Gombrowicz, Dziennik, t. 1: 1953-1956, s. 323.

${ }^{25} \mathrm{~K}$. A. Jeleński, $O$ Gombrowiczu, [w:] CO, s. 462.

${ }^{26}$ Tenże, Bohaterskie niebohaterstwo Gombrowicza, [w:] CO, s. 37.

${ }^{27}$ Tenże, „Ferdydurke” po pięćdziesięciu latach, [w:] CO, s. 365.
} 
ści, która tworzy jedynie iluzję autentyczności. Było to odkrycie, do którego wiele lat później, w latach 60., dochodziła dopiero myśl Zachodu (Foucault, Lévi-Strauss, Lacan, Althusser), odrzucająca wartość świadomości na rzecz podświadomości. Jeleński podkreśla pionierstwo Gombrowicza w tym zakresie, który już trzydzieści lat wcześniej zapisał w Ferdydurke taki ustęp:

Wkrótce poczniemy obawiać się naszych osób i osobowości, stanie się nam jasne bowiem, że one bynajmniej nie są w pełni nasze. I zamiast ryczeć: Ja w to wierzę, ja to czuję, ja taki jestem, ja tego bronię — powiemy z pokorą: mnie się w to wierzy, mnie się to czuje, mnie się to powiedziało $[\ldots]^{28}$.

W czym jeszcze upatrywał wielkość pisarza Jeleński, a co mogłoby w jakiś sposób przemycić informację o nim samym (tj. Jeleńskim)? Istotne dla obu było pojęcie „,polskości” i — zaśniedziałe już — powszechne jego rozumienie, które chcieli odświeżyć, lub, mówiąc dosadniej, uczynić właściwym. Obaj polemizowali z ojczyzną. Irytujące kompleksy rodaków, o których co krok wspomina Gombrowicz w Dzienniku, nie pozwalały na przyjęcie faktu o polskiej kulturze, która jest, względem Zachodu, po prostu „Z drugiej ręki”. Na tym niemym wstydzie Polaków budował swoje dzieło Gombrowicz - obnażał. Sam miał oczywiście także własne słabości, które wyrażały się w, akcentowanym przez niektórych, a dość otwarcie i swobodnie zdefiniowanym przez Jeleńskiego, snobizmie. Po latach ${ }^{29}$ Jeleński tłumaczył swoisty snobizm Gombrowicza toksycznym środowiskiem, stale obserwującym i oceniającym. Presja wywierana przez arystokrację (nota bene nie mającą z prawdziwą arystokracją wiele wspólnego) budziła u pisarza kompleksy, ale jednocześnie bunt, który leżał u podstaw tworzenia. Sprzeczne koło się zamykało - tkwił bowiem Gombrowicz w tej aurze, którą stale krytykował (z tą jednak różnicą względem większości, że miał świadomość jej koturnowości). W liście Jeleńskiego do redakcji „Twórczości” z roku 1986 pojawia się taka oto paralela, łącząca Balthusa z Gombrowiczem:

Imaginacyjne hrabiostwo jednego i drugiego przypisuję w pierwszym rzędzie paradoksalnej sytuacji dwóch wielkich artystów naszych czasów, którzy za wszelką cenę chcieli się odciąć od awangardy. Nałożyli sobie te towarzysko-cierniowe (bo śmieszne) korony, jako jawny znak swego przemyślanego i rozmyślnego anachronizmu: Gombrowicz, by z sarmackiego baroku czerpać tworzywo swej wizji rzeczywistości $[\ldots]^{30}$.

Bliższy prawdy dotyczącej snobizmu i kompleksów Gombrowicza oraz jego pretendowania do sfery wyższej jest jednak chyba Jerzy Jarzębski, który, wspominając Jeleńskiego, mówi:

On był naprawdę człowiekiem Zachodu. On się nigdzie nie czuł na Zachodzie kimś gorszym. Nie tylko dlatego, że świetnie znał języki, ale również z uwagi na urodzenie. Był skoligacony ze znanymi, świetnymi rodami arystokratycznymi przez Czapskich. [...] To jest opuszczenie rodzimego paradygmatu. W zamian zyskuje się pewną swobodę, pewien dystans do idei sformułowanych na Zachodzie i brak kompleksów, który czasami bywa bardzo ważny. To jest to, czego dopracowywał się Gombrowicz, ponie-

${ }^{28}$ Tamże, s. 368.

${ }^{29}$ W eseju Bohaterskie niebohaterstwo Gombrowicza z roku 1957 Jeleński notował jeszcze: „Nic również w Gombrowiczu z tak bardzo polskich czytanek z zachodniej kultury, nic z mody czy ze snobizmu" (s. 37). Wspominając Gombrowicza po jego śmierci miał już jednak świadomość jego słabości; zob.: K. A. Jeleński, O Gombrowiczu, s. 463-465.

${ }^{30}$ K. A. Jeleński, List do redakcji, Twórczość 1986 nr 7, s. 140-141; zob. także: Zeszyty Literackie $2001 \mathrm{nr} 74$, s. 87 i CO, s. 165. 
waż nie miał tego z urodzenia. On musiał na Zachodzie „stanąć na głowie”, by zrzucić z siebie balast polskości, a i tak go nie zrzucił do końca ${ }^{31}$.

Jeleński często podkreślał, że pochodzi z tego samego środowiska, co Gombrowicz — stąd rewelacja, jaką okazało się Ferdydurke. Mimo wszystko, jak zauważa w cytowanym fragmencie Jarzębski, dzieliła ich pewna świadomość przynależności (a w przypadku Gombrowicza właśnie jej braku) do szeroko pojętej kultury europejskiej jako własnej. Wynikający stąd snobizm Gombrowicza ${ }^{32}$ musiał różnić się od snobizmu Jeleńskiego, o którym wspomina Bernard Minoret:

Jego snobizm prawdziwy, choć rzadko praktykowany, ograniczał się do największych nazwisk arystokracji europejskiej, przede wszystkim polskiej. Lecz były to raczej u niego igraszki umysłu i nie czynił sobie bynajmniej złudzeń na temat Almanachu Gotajskiego, o którym lubił rozprawiać, nie znosząc tam bywać. Gdybyśmy się posunęli trochę dalej, można by powiedzieć, że snobizm Kota był czysto intelektualny $[\ldots]^{33}$.

Z sytuacji musiał sobie z czasem zdawać sprawę Jeleński, Gombrowicz jawił mu się jednak jako postać, mimo wszystko, bardzo autentyczna:

Przy całej sztuczności obserwowanych konwencji był doskonale naturalny. Jedna z najbardziej naturalnych osób, jakie znałem. Właśnie z powodu tej jego podejrzliwości wobec wszystkiego, co spontaniczne. Kiedy ktoś do tego stopnia potrafi zintegrować swą fizyczność z psychicznością, nie może być inny ${ }^{34}$.

Wszelkie strzały w kierunku Gombrowicza przechwytywał i odbijał tarczą swojego argumentu, jego dziełu oddał się bez reszty, potraktował je jak swoje, bo dotyczyło go osobiście, było pisane o nim i o tym, co dokoła, otworzyło mu oczy i usta. O samym autorze pisał: „Był jakby projekcją mnie samego, ale wyrazistszą, bardziej udaną, doskonalszą i jednocześnie jakby nieszczęśliwszą"35. Ale to, co Jeleńskiego zdawało się najbardziej urzekać w dziele gombrowiczowskim, to przede wszystkim otwarta walka z samym sobą, jawne obnażanie własnych słabości, akceptowanie ich, przy jednoczesnym poszukiwaniu remedium, które mogłoby z czasem wyrazić się w wolności i umocnieniu. „Tego rodzaju przedsięwzięcie przyjęcia pełni odpowiedzialności za siebie samego, posunięcia do najdalszych granic wszystkich swoich cech, ma zawsze charakter bohaterski"

${ }^{31}$ J. Jarzębski, Jeleński... Kto to? (z J. Jarzębskim rozmawia Z. Kudelski), Kresy 1995 nr 22, s. 227.

${ }^{32}$ Sprawę obrazuje słynna anegdota o pocztówce wysłanej przez Jeleńskiego do Gombrowicza - tu we wspomnieniu Zofii Hertz: „muszę otwarcie przyznać, że ani ja, ani Zygmunt nie lubiliśmy go [tj. Gombrowicza]. Denerwował nas swoim „nadęciem” oraz tym, że uważał się za pępek świata. [...] Gombrowicz był strasznym snobem, a nic mu tak nie imponowało, jak kontakty ze środowiskiem arystokracji. Kiedyś Kot Jeleński, który go uwielbiał, postanowił z niego zażartować i będąc z Leonor Fini na wakacjach na Korsyce, napisał do niego kartkę z pozdrowieniami. Kartkę tę podpisała Leonor oraz Kot, który różnymi charakterami pisma wypisał nazwiska pięciu hrabiów, kilku książąt i paru najlepszych pisarzy paryskich jako tych, którzy dołączyli się do pozdrowień dla Gombrowicza. I tak tę kartkę wysłał. Po jakimś czasie przyszedł kolejny odcinek Dziennika, w którym Gombrowicz napisał, że ma znajomości w wielkim świecie i przepisał z kartki Kota nazwiska tych ceniących go ludzi we Francji! Z trudem udało się nam go przekonać, aby tego nie drukował”; I. Chruślińska, Byta raz „Kultura”... Rozmowy z Zofia Hertz, Lublin 2003, s. 73-74.

${ }^{33}$ B. Minoret, Z listów do Piotra Kłoczowskiego, s. 43.

${ }^{34}$ K. A. Jeleński, O Gombrowiczu, s. 474.

35 Tamże, s. 459. 
— pisał z podziwem ${ }^{36}$. W nagranej przez Ritę Gombrowicz wypowiedzi wspomina, że ten bój o przebudowę własnej niemocy w wartość realną miał też kapitalny wpływ na czytelników, dla których pisarz był poniekąd opiekunem, przewodnikiem po nich samych:

[...] u podstaw tego nowego humanizmu, niezwykle subtelnego i chytrego, odnajdujemy zawsze fundamentalne przerażenie. Waga Gombrowicza polega nie tyle na jego cudownej zawsze inteligencji — umiejętności zobaczenia wszystkiego „na nowo” — czy na jego własnej psychologii intuicyjnej, ile na niewiarygodnym jego wysiłku, by nas przybliżyć do najbardziej tajemniczych fundamentów bytu. Gombrowicz, który tyle sytuacji ludzkich nam wyjaśnił, jest wielkim artystą właśnie przez wysiłek pokazywania nam tego, czego ani on, ani nikt inny nie potrafi nigdy „wyjaśnić”. Był nie tylko człowiekiem wielkiej odwagi intelektualnej, był także obdarzony wielką odwagą egzystencjalną $^{37}$.

Temat, który zarówno dla Gombrowicza jak i Jeleńskiego okazywał się w literaturze (szerzej: kulturze) ważki, i który — jeden pośrednio, drugi całkiem wprost — komentowali, to problem erotyzmu, który według Jeleńskiego stanowi nieodzowne zaplecze każdego utworu Gombrowicza. Męczyła ich obu pruderia — w recenzji Gry w Gombrowicza Jerzego Jarzębskiego Jeleński pisze:

Polska kultura ma spore kłopoty z erotyzmem — i to nie od dzisiaj. Pozornie kontrasty prymitywne: rubaszność i świntuszenie przy wódce, purytanizm i sentymentalizm z piórem w ręku. Podejrzewam (optymistycznie), że zatajony podziemny polski erotyzm jest bardzo silny, że działają tu automatyzmy samozachowawcze, niejasne przeczucie, że wywlekanie wszystkiego na światło dzienne, ,wyzwolenie” i usankcjonowanie seksu nie służą pożądaniu i rozkoszy ${ }^{38}$.

Nieporozumieniem według obu było zatajanie wszelkich erotycznych akcentów, które świadczą przecież o ruchu emocji, przynoszą zaskoczenie, lęk, koncentrują uwagę czytelnika i — co być może najważniejsze — jako naturalne stają się niezbędne na drodze poznania (a na pewno: poznawania).

Podobnie przedstawiała się sprawa z przyjętymi w polskiej literaturze ogólnymi paradygmatami postaw, propagujących określoną wizję Polaka, jak i polskości, a będących w istocie konsekwencją idealizującej — i według Gombrowicza nudnej, niepełnej — koncepcji człowieka. To, co — zarówno dla Gombrowicza, jak i dla Jeleńskiego — piękne, to nie sztuczny, idealny wytwór, lecz możliwie najprawdziwszy. Uroda bowiem obejmuje nie tylko to, co w powszechnym rozumieniu dobre i prawe. Uroda to spectrum wszystkich atrybutów człowieczeństwa. Ponadto te niedoskonałe, jako bardziej skomplikowane, nieoczywiste są przeważnie bardziej atrakcyjne:

Piękność, twierdzi Gombrowicz, potrzebna jest nie tylko jednostce, ale również narodom, które „Zwracają się do swoich artystów, aby oni wydobyli z nich piękność i stąd w sztuce piękność francuska, angielska, polska lub rosyjska”. Nad wytworzoną w ten sposób „urodą polską” ciąży swoiste przekleństwo, gdyż literatura nasza od zarania „,utożsamia urodę z cnotą”. Jest to dla Gombrowicza pomyłka zasadnicza, ,gdyż cnota, sama w sobie, jest nieciekawa i z góry wiadoma, cnota jest załatwieniem sprawy, to jest śmiercią; grzech jest życiem”. Dlatego „kto od dzieciństwa był tylko cnotliwy” (a więc, uzupełnijmy, literatura polska), ten „niewiele będzie wiedział o sobie”. [...] Na skutek paru wieków sumienia, powiada Gombrowicz, typ Polaka, jaki proponowała literatura

\footnotetext{
${ }^{36}$ Tenże, Bohaterskie niebohaterstwo Gombrowicza, s. 47.

${ }^{37}$ Tenże, O Gombrowiczu, s. 470.

${ }^{38}$ Tenże, Grajmy w Gombrowicza, [w:] CO, s. 338.
} 
i sztuka, nie będąc dosyć nasycony grzechem, dość związany z życiem, musiał stać się oderwaną formułą [...]. ${ }^{39}$

Nie bez kozery wiele osób nazwało Jeleńskiego „pełnym energii sobowtórem” Gombrowicza. Oczywistym jest jednak, że w pewnych punktach się różnili. Znamienne jest tu podejście obu do poezji. Wrażliwość Jeleńskiego nie pozwala mu oczywiście pozostawać wobec niej obojętnym. Komentował poezję, od wczesnej młodości także ją tłumaczył, interesowali go też sami poeci, ich natura. Dla Gombrowicza poezja właściwie nie istniała, choć, jak pisze Jeleński, jego esej Przeciw poetom nie jest w gruncie rzeczy skierowany przeciw ,poezji wierszowanej”, atakuje jedynie konkretny typ literatury wtórnej, opartej na zużytych kliszach, wzdychającej nad sztucznie wytworzonym ,pięknem”. Gombrowicz atakował czymś nowym, zupełnie swoim. Myślę, że paradoksalnie właśnie za to uwielbiał go Jeleński, widząc jednocześnie pewien potencjał w języku ,klasycznym”, logicznie ułożonym, niejako już znanym. Gombrowicz był konsekwentny w swojej postawie, należał do tych ludzi o typie już uformowanym, pełnym, zamkniętym, więc prawdopodobnie wrażliwość Jeleńskiego, z którą miał kontakt, też nie mogła okazać się w tej mierze influencyjna. Być może poezja była dla niego formą przesadnie dekoracyjną, a pamiętajmy, że kultura miała Gombrowiczowi służyć przede wszystkim do zrozumienia siebie. Musiał najprawdopodobniej odnajdywać w niej pierwiastek znienawidzonej pretensjonalności.

Punktem, w którym także się rozmijali, choć już nie tak radykalnie, było spojrzenie na paryskie wydarzenia z maja roku 1968, z którymi Jeleński wiązał dzieło Gombrowi$\mathrm{cza}^{40}$ — jak się potem okazało wbrew woli pisarza. Entuzjazm Jeleńskiego, do którego jeszcze wrócimy, ochłodzony był racjonalnym wytknięciem wewnętrznych sprzeczności ruchu, jego utopijnych postulatów. W przypadku Gombrowicza o żadnym entuzjazmie raczej mówić nie można. Podobnie przyjął majową rewolucję Iwaszkiewicz, który w liście do Gombrowicza pisał:

[...] czytałem artykuł Kota o majowej rewolucji, który mi się podobał (względnie) oprócz zakończenia, gdzie kreuje Ciebie na proroka rewolucji młodzieżowych. Wydało mi się to głupstwem wierutnym — i strasznie mnie ucieszyłeś odżegnując się od tego. Uważam Ciebie i Twoje pisarstwo za rzeczy milion razy poważniejsze niż działalność Cohn-Bendita, chociażby nawet pozostawił on jakiś trwały ślad polityczny. Filozofia tych młodych jest beznadziejna. [...] Bardzo się cieszę, że się od tego odcinasz. Masz rację, że trzeba myśleć na długą metę, czasami na bardzo długą metę. Jak ja zawsze powtarzam, że pierwszą cnotą pisarza (i filozofa, co na jedno wychodzi) musi być cierpliwość ${ }^{41}$.

Te, charakterystyczne dla obu, pojedyncze differentia specifica nie zakłócały jednak nadto pewnej jedności, na którą składa się szereg elementów spajających ich widzenie świata. Dla obu największym kłamstwem były ideologie: „Gombrowicz wiedział od zawsze, że idee to sita, przez które życie przecieka" — pisał Jeleński. Sercem obaj byli na lewicy, zawsze jednak czujnie:

„Jestem ateista, poza tym filosemita, poza tym autor awangardowy i nawet «burzyciel» poniekąd... Jakże mógłbym być ciasnym konserwatystą?" — powiada Gombrowicz. A gdzie indziej słusznie zauważa, że lewica zawsze była wrodzonym terenem jego

${ }^{39}$ Tenże, Tajny ładunek korsarskiego okrętu, [w:] CO, s. 410.

${ }^{40}$ Zob.: tenże, Notatki o „majowej rewolucji”, [w:] ZO I, s. 165.

${ }^{41} \mathrm{Z}$ listu J. Iwaszkiewicza do W. Gombrowicza z 23 lipca 1968; zob.: Gombrowicz — walka o stawe..., t. 1, s. 175. 
działania. Powinien był dodać: tylko dopóki lewica jest buntem, negacją, subwersją, antykonformizmem. Skoro tylko lewica zastyga w ideologię ,konstruktywną”, skoro tylko zaczyna opanowywać taki czy inny sektor kultury, Gombrowicz ją zwalcza ${ }^{42}$.

Podobnie nieufni byli w sprawach religii - katolicyzm był dla nich nie do przyję$\mathrm{cia}^{43}$. Łączyły ich także pewne względy prywatno-obyczajowe. Nie jest tajemnica zamiłowanie Jeleńskiego do mężczyzn (a właściwie do obu płci). O swojej ,,pederastii” pisał m.in. w listach do Józefa Czapskiego ${ }^{44}$, o skłonnościach tych pisze też we wspomnieniach o Kocie Czesław Miłosz w swoim Abecadle i Roku myśliwego ${ }^{45}$. Podobnie z Gombrowiczem, który świadectwo swych biseksualnych upodobań zostawił chociażby na kartach $D_{z i e n n i k a^{46}}$. Są to sprawy zbyt intymne, aby penetrować je dogłębnie.

${ }^{42}$ K. A. Jeleński, Od bosości do nagości. O nieznanej sztuce Witolda Gombrowicza, [w:] CO, s. 288-289.

${ }^{43}$ Jak pisze J. C. Gómez: „Gombrowicz wierzył w Boga do czternastego roku życia i porzucił wiarę bez żadnych teatralnych gestów, nigdy nie czuł potrzeby wiary. Jednakże nie był też ateistą. Dla człowieka, który stał twarzą w twarz z tajemnicą egzystencji, możliwe było każde rozwiązanie, nie mógł być ateistą. $\mathrm{Z}$ trudem przychodziło mu utrzymywanie kontaktu z katolicyzmem, bo ta doktryna stała w sprzeczności z jego światopoglądem, jednakże kryzys intelektualny stawał się groźny i budził w nim większą nieufność niż sam katolicyzm. [...] Początkowo przeciwstawiał powierzchowny katolicyzm Sienkiewicza tragicznemu i głębokiemu katolicyzmowi Simone Weil, dzięki któremu możliwe było znalezienie wspólnego języka między religią i współczesna literatura, później jednak oddala się od Weil i znowu zbliża do Sienkiewicza, bo, jak mówi, stał się zwolennikiem miernoty, średnich temperatur i wrogiem skrajności. Ogólnie rzecz biorąc myślał, że kiedy katolicy zaczynają pisać, wycierają sobie nos duszą zamiast robić to chusteczką"; J. C. Gómez, Zapiski gombrowiczowskie, przeł. E. Zaleska, Twórczość $2008 \mathrm{nr}$ 11, s. 77-100. Zarys ten zdaje mi się w znacznej części odpowiadający także stanowisku Jeleńskiego.

${ }^{44}$ Zob.: K. A. Jeleński, Listy z Korsyki do Józefa Czapskiego, oprac. W. Karpiński, Warszawa 2003, s. 10-11, s. 15-17 (list z 26 sierpnia 1952; list z lata 1953).

${ }^{45}$ Miłosz notuje tam: „Jeleńskim byłem, jak inni, oczarowany. I zazdrościłem. Czego? Pełnego życia, bo uważałem, że jest z lepszego metalu niż ja, mimo jego strefy dla mnie mrocznej — która, jak opowiadała mi Leonor, istniała także, kiedy w 1950 roku poznali się w Rzymie jego pasji do ragazzi”; Cz. Miłosz, Rok myśliwego, Kraków 2001, s. 18. Por. także: K. Martel, Kot Jeleński, Inaczej 1997 nr 3, s. 12; K. Tomasik, Pierwszy homoseksualista emigracji, [w:] tegoż, Homobiografie, Warszawa 2008.

${ }^{46}$ W roku 1955 Gombrowicz zapisał: „ślepa i głucha na wszystko obsesja zaczynała opanowywać mnie całkowicie, umysł mój pracował — zdawałem sobie sprawę, że zabrnąłem gdzieś na niebezpieczne pogranicze i, naturalnie, pierwsze co mi przyszło do głowy to iż torują sobie we mnie drogę podświadome homoseksualistyczne skłonności. I może z zadowoleniem powitałbym ten fakt, gdyż on przynajmniej umieściłby mnie w jakiejś rzeczywistości - ale nie, w tym samym czasie nawiązałem bliższe stosunki z kobietą, których intensywność nie pozostawiała nic do życzenia. I w ogóle w tym okresie dość dużo razy chodziłem za dziewczynkami, nieraz nawet trybem dość skandalicznym"; W. Gombrowicz, Dziennik, t. 1, s. 209-210. Warto być może przytoczyć także humorystycznie brzmiącą wypowiedź Andrzeja Banacha, który wspominał spotkanie z Gombrowiczem w Paryżu: „Może moje wrażenia były tak negatywne, bo przepraszam bardzo, ale naprawdę nie znoszę homoseksualistów. Jestem absolutnym wielbicielem kobiet, kobiecości. Poza tym, nie oszukujmy się - w jego sukcesach bardzo mu niewątpliwie pomogli panowie o podobnych skłonnościach... Nazwisk chyba nie muszę wymieniać — wszyscy dobrze je znają. Oczywiście, że wybił się już w Argentynie. Książek też za niego nie napisali. Ale proszę uwierzyć staremu pisarzowi - popierają się jednak nawet i przez kontynenty lansowanie, wydawanie, to przecież bardzo dużo. Naprawdę mają coś w rodzaju swojej między- 
Warto mimo wszystko je zasygnalizować, być może determinują one pewne wybory estetyczne, pogląd na religię, politykę — być może też nie mają najmniejszego znaczenia. Homoseksualizm w dziele Gombrowicza ma jednak swoją wymowę głębszą w eseju poświęconym Historii, niedokończonej sztuce pisarza, Jeleński przytacza komentarz samego Gombrowicza:

[...] opisując w Rozmowach Trans-Atlantyk, Gombrowicz jakby identyfikuje homoseksualizm z „wolnością stwarzania się”: „Ja, Gombrowicz, zawieram znajomość z puto (pedek) [sic!'] zakochanym w młodym Polaku i okoliczności czynią mnie arbitrem sytuacji: mogę pchnąć młodzieńca w objęcia pederasty lub sprawić, by przy ojcu został — zacnym i honorowym majorze polskim starej daty.

Pchnąc go w objęcia puto, to wydać zboczeniu, zepchnąć na bezdroża w odmęt dowolności, w bezgraniczność anormalności. Wydrzeć go pederaście i przywrócić ojcu, to utrzymać go w dotychczasowej, tradycyjnej bogobojnej postawie polskiej. Co wybrać? Wierność przeszłości czy wolność dowolnego stawania się? Przykuć do dawnego kształtu... czy dać swobodę i niech robi ze sobą, co chce! Niech sam się stwarza!" ${ }^{, 7}$.

Gombrowicz był dla Jeleńskiego lekarstwem na zastygłą, zacofaną polskość. Był krokiem naprzód, powiewem świeżości. Obaj zdawali sobie sprawę, że dzieło Gombrowicza nie jest wystarczająco znane w kraju i być może nie tylko cenzura była tutaj problemem. Pod koniec życia, Jeleński, odpowiadając na ankietę pisma „Res Publica”, dotyczącą najistotniejszych wydarzeń w kulturze w roku 1986, tak komentował polskie wydanie dzieła Gombrowicza:

Nigdy nie był potrzebniejszy, tym bardziej że ostatnimi czasy przeżywa w Polsce gorszą passę, jest jakby odrzucany. Tymczasem Polska staje się krajem Syfonów, i koniecznie powinno urodzić się w niej więcej Miętusów, po to, by stała się krajem normalniejszym. Gombrowicz potrzebny jest dla przyjemności, dla nauki, dla zabawy i zwalczania polskiej gęby patriotycznej. Uczy zaciekawienia życiem: żyjemy przecież w codzienności i naszą codziennością powinniśmy być zafascynowani. A nie udawać, że ma się stale czterdzieści stopni gorączki i na oku wyłącznie wielkie cele. Ulubionym słowem Gombrowicza jest „rozluźnienie” i to rozluźnienie, odetchnięcie Gombrowiczem wydaje się dzisiejszym Polakom ogromnie potrzebne ${ }^{48}$.

Tytułem podsumowania tej części i przejścia do kolejnej, chciałbym zaakcentować rzecz, którą Jeleński zauważa w tekście Bohaterskie niebohaterstwo Gombrowicza (1957). Wspomina w nim o myśli autora Pornografii, która „,przylega ściśle do jego [tj. Gombrowicza] życia”, której nie można od niego oderwać — jest z nim zespolona na stałe: pisząc, dokonuje „daru samego siebie”. Nie inaczej jest z samym Jeleńskim, który, choć wielokrotnie „używa” cudzej myśli, sylwetki lub innego dzieła, robi to w celu wyrażania siebie, szukania własnej perspektywy, czasem nawet podobnego doświadczenia osobistego - w gruncie rzeczy pisze ,przez siebie” i często wręcz o sobie.

\section{Coś z własnych zachwytów}

„Nigdy nie pisz o autorze ani o jego dziele — tylko o sobie w konfrontacji z dziełem albo autorem. Tylko o sobie wolno ci pisać" — ta dyrektywa Gombrowicza zdaje się mieć wyraźne odzwierciedlenie w pisarstwie Jeleńskiego, można zaryzykować

narodówki...”; J. Siedlecka, Jaśnie Panicz, Warszawa 2004, s. 233. Por. także: K. Tomasik, Homoseksualizm za maska. O Witoldzie Gombrowiczu, [w:] tegoż: Homobiografie.

${ }^{47}$ K. A. Jeleński, Od bosości do nagości..., s. 295.

${ }^{48}$ Cyt. za: P. Kłoczowski, Noty do tekstów, [w:] CO, s. 37. 
nawet stwierdzenie, że stanowi ona poniekąd dla części jego pisarstwa cechę dystynktywną, dla wielu tekstów swoistą, opisującą kontakt krytyka z dziełem. Nie oznacza to — co oczywiste, ale podkreślmy — że boi się on formułować tezy dotyczące autorów, że literacki świat przedstawiony jest dla niego na tyle abstrakcyjny, że pozostawia go bez żadnego komentarza.

Jeleński nie pisał o przypadkowych lekturach, o książkach, które w żaden sposób go nie dotykały ${ }^{49}$. Nie zawsze, choć stosunkowo często, były to zbieżności z osobistym przeżyciem, z chwilą znaną, pokrewną.

Był przykładem krytyka, dla którego dzieła istnieją nie jako zamknięte w sobie, autonomiczne struktury, ale jako emanacje żywych ludzi — uważał zatem, że z tymi ludźmi trzeba się niejako utożsamić, jeśli chce się właściwie odczytać dzieła same. Toteż przyjaźń z autorami, którą kultywował jako wartość samoistną, była dlań również kluczem do zrozumienia ich dziet ${ }^{50}$.

W eseju $O$ „Ziemi Ulro” po dwóch latach (1979) Jeleński pisze, że czytając poezje Miłosza odczuwa ,w sobie coś z własnych zapamiętanych zachwytów, coś z rezygnacji (ale niemal radosnej)" ${ }^{\prime 51}$. Lektura Ziemi Ulro jest dla niego pretekstem, jego komentarz do niej ma w gruncie rzeczy charakter autobiograficzny. Postaci, którym przygląda się w swojej książce Miłosz (Blake, Swedenborg, Oskar Miłosz, Mickiewicz) pozostały nie bez znaczenia również na drodze Jeleńskiego, który podkreśla jednak, że jego rozwój, a przez to kontakt z nimi, miał charakter zgoła odmienny ${ }^{52}$. Jasno mówi, że nie podziela we wszystkich punktach fascynacji Miłosza — nie może być jego ,czytelnikiem idealnym”. Osoby, do których nawiązuje Miłosz, nie były nigdy dla Jeleńskiego, jak dla autora Trzech zim, „eschatologicznymi prorokami”, ich dzieło tak pojmowane jest mu obce. To, co jest w nich dla niego pociągające, to przede wszystkim dyspozycja do wychwytywania tak bliskich mu ,ukrytych związków pomiędzy poszczególnymi przedmiotami i istnieniami”. Widzi Jeleński w Ziemi Ulro jednak wyraźnie zarysowaną część, traktującą o cywilizacji chrześcijańskiej (będącej nota bene w fazie kryzysu), a więc o tych, którzy — jak pisał Miłosz — oczekują ,innego nieba i innej ziemi”. To utrudniało pełne utożsamienie, przyniosło jednak refleksję bardzo osobistą:

Myślę, że gdybym był wierzący, to na sposób Miłosza. Wstydzę się dziś, że długo byłem ateistą nie tylko antyklerykalnym, antyreligijnym nawet, że odczuwałem nad wierzącymi naiwne poczucie wyższości. Mam nadzieję, że stałem się z biegiem lat tym „,ateistą prawdziwym”, o którym pisze Miłosz, że religia winna być dla niego „godnym podziwu tworem ludzkiej wyobraźni" $[\ldots]^{53}$.

${ }^{49}$ Uogólnienie to dotyczy jego eseistycznej części pracy — pisał bowiem o wielu książkach, często jednak jedynie w formie skromnych not — prowadził swego czasu w „Kulturze” rubryki „Notatki wydawnicze” i „Przegląd miesięczników” („Przegląd czasopism”). Pisząc o nowościach wydawniczych, w samych latach 1953-1955 omówił 130 książek, wydanych w wielu językach; por.: J. Kandziora, Wprowadzenie, [w:] Konstanty Aleksander Jeleński w wydawnictwach instytutu Literackiego w Paryżu. Bibliografia, oprac. tenże, Warszawa 2007, s. 11.

${ }^{50}$ K. Pomian, Jeleński: szkic do portretu, [w:] tegoż, W kręgu Giedroycia, Warszawa 2000, s. 166.

${ }^{51}$ K. A. Jeleński, $O$ „Ziemi Ulro” po dwóch latach, [w:] CO, s. 10.

${ }^{52} \mathrm{~W}$ jednym z listów Jeleńskiego do Józefa Czapskiego czytamy: „Co prawda znam dobrze Blake'a, Swedenborga czytałem, kiedy pasjonowałem się 25 lat temu Jungiem i René Guénon Oskara Miłosza podziwiam ogromnie, ale właściwie za powieść L’Amourese initiation, która jest arcydziełem, ale wierszy jego nigdy nie zrozumiałem...”; K. A. Jeleński, Listy z Korsyki..., s. 53.

${ }^{53}$ K. A. Jeleński, O „Ziemi Ulro” po dwóch latach, s. 13. 
Wcześniej, w liście do Miłosza z roku 1976, pisał o Ziemi Ulro jako „najważniejszej” i ,najpiękniejszej” jego rzeczy prozą. Dodawał także:

Znalazłem tam wiele pokarmu dla siebie, mimo (a może dlatego) że z książki Twej wynika, że jestem prawdziwym ateistą (wyjaśnia mi to zresztą dlaczego Gombrowicz odegrał w moim życiu taką rolę). Myślę, że się mylisz myśląc, że Zachód (w każdym razie Europa) jeszcze tkwią całkowicie w Ziemi Ulro. Mam wrażenie, że najbardziej żywe prądy dzisiaj są reakcją przeciw sakralizacji rozumu (która rozum spacza) i potwierdzeniem „obecności mitu”. [...] Zasadniczą między nami różnicą jest, że nie uważam człowieka za ośrodek wszechświata, ale za gatunek, który musi tak żyć jak gdyby nim by ${ }^{54}$.

Ziemia Ulro nie jest jednak dla Jeleńskiego jedynie tekstem dotyczącym szeroko pojętej kwestii wiary, co umożliwia mu także recepcję bardziej emocjonalną — odnajduje tam bowiem również refleksje na temat wyobraźni i jej źródeł, przy okazji których wprowadza Miłosz takie postaci jak Gombrowicz czy Jacques Monod — obaj, każdy na swój sposób, byli Jeleńskiemu bardzo bliscy.

W wielu miejscach Miłosz pomaga dostrzec Jeleńskiemu szczegóły, które (przy zetknięciu przed laty z opisywanymi w Ziemi Ulro postaciami) mógł pominać. Nie zmienia to jednak faktu, że w wielu ustępach Jeleński nie może zgodzić się z Miłoszem - będąc po części krytykiem niektórych aspektów nowoczesności, nie podziela całościowej jej krytyki — podobnie jak Gombrowicz zdaje sobie bowiem sprawę, jak bardzo ową współczesnością jest nasączony i jak niewiele znaczący okazałby się gest jej odrzucenia. $Z$ dystansem także odnosi się do ataku Miłosza na dziedzictwo oświecenia. Przywołując myśli ulubionego Lichtenberga, pragnie zaprzeczyć przekonaniu Miłosza, odrzucającego możliwość uniknięcia wyboru między „,czuciem i wiarą” a „mędrca szkiełkiem i okiem". Jeleński czuł bowiem, że barierę rozumu i uczucia można przełamać, że temu dualizmowi nie warto się poddawać. Jednocześnie nie zgadzał się również z twierdzeniem, co w kontekście całej książki chyba najistotniejsze, jakoby wiara była jedyną perspektywą ucieczki od ery konsumpcji (bliższe jest mu oczywiście stanowisko, które w książce reprezentuje postać Gombrowicza).

W tym sporze o nowoczesność, Jeleński ciekawie zaciera ślady swojej końcowej opinii na temat teokratycznej „,odnowy”, jakiej nadzieję wyraża książka Miłosza. Z jednej strony w żadnym stopniu nie podziela wiary w taką możliwość, $\mathrm{z}$ drugiej zaś zdaje sobie sprawę, że obecną cywilizację czeka jakaś zmiana i wie, że nie będzie ona dziełem jej samej (tj. cywilizacji) - powołuje się tu na fragment z książki Krzysztofa Michalskiego Heidegger i filozofia wspótczesna, cytując:

Nie zrobi tego sama z siebie i bez niczyjej pomocy — lecz opierając się na gotowości człowieka do podjęcia wezwania, które zawsze, słyszane czy nie, apeluje do nierozstrzygniętego jeszcze ludzkiego losu 55 .

I dodaje od razu:

Myślę, że takie należy przypisać znaczenie Miłoszowej „odnowie”. Perspektywa jej jest daleka, ale jedynie ona może nas uchronić przed podwójnym mieczem Damoklesowym $[\ldots]^{56}$.

W liście do Józefa Czapskiego odnajdujemy zaś fragment:

\footnotetext{
${ }^{54}$ Tenże, Z listów do Czesława Miłosza, Zeszyty Literackie $1995 \mathrm{nr}$ 50, s. 80.

${ }^{55}$ Tenże, $O$,Ziemi Ulro” po dwóch latach, s. 30.

${ }^{56}$ Tamże.
} 
Z artykułem o Ziemi Ulro miałem [...] ogromne trudności [...] również dlatego, że nie podzielam ani wiary Czesława, ani nadziei przemiany w kierunku „powrotu Boga-człowieka" (a już w żadnym stopniu ,teokracji”) ${ }^{57}$.

Do słów tych powrócimy przy okazji omawiania stosunku Jeleńskiego do religii — już tu jednak warto zasygnalizować i podkreślić rzecz ciekawą: Bóg? Niekoniecznie powiedziałby Jeleński. Ale kosmiczny „nierozstrzygnięty los ludzki” — jak najbardziej. Tu także ujawnia się szczególna cecha Jeleńskiego: dyskurs Miłosza przykłada do swojego światopoglądu i potrafi, mimo wielu różnic, znaleźć z nim wspólny (podobny) mianownik.

Pomimo niektórych różnic światopoglądowych, Jeleński odnajdywał w dziele jak i osobie Miłosza liczne punkty, z którymi mógł swobodnie się utożsamiać na wielu poziomach. W recenzji dwóch książek, będących zapisem wywiadów z Miłoszem ${ }^{58}$ zauważa:

Książka Fiuta wydaje mi się szczególnie cenna, jeśli chodzi o cechy tego, co Miłosz określa jako swoje ,jakby rozchwianie narodowe”. Nie może już nazwać siebie, jak jego profesor Sukiennicki, Litwinem mówiącym po polsku, „bo takich zwierząt już właściwie nie ma”. Młode pokolenie polskie nie ma pojęcia, czym była polskość na Litwie, przywiązanie naszych ojców i dziadów do Polski, a zarazem i niechęć, zabarwiona politowaniem dla „,koroniarzy”, ${ }^{, 59}$.

Jeleński, pomimo niewielu lat spędzonych w Polsce, czuł z nią silną więź - mało tego, litewskie korzenie jego ojca zapewne sprawiły, że także i Kresy darzył wyjątkowym sentymentem. W liście do Miłosza pisał:

Skąd na przykład ja - urodzony w Warszawie, dzieciństwo spędzone w rodzinie matki (po obu stronach „Koroniarki”), rodzice wyobcowani, ,kosmopolici”, wykorzenieni, ,pogardzający tradycją" (ale niestety nie snobizmem, do którego się — biedni — broń Boże nie przyznawali) — skąd ja od dziecka uważałem się mimo wszystko za „Litwina”? ${ }^{60}$.

Można zatem mówić o naturalnym, mimowolnym, czystym poczuciu przynależności. Na tym gruncie dzieło Miłosza musiało być bliskie Jeleńskiemu, można nawet zaryzykować hipotezę, że historyczne zakorzenienie Miłosza było w tym wypadku spoiwem najmocniejszym. Potwierdzenie przynosi korespondencja, w której Jeleński przyznaje, że tak jak dzieło Gombrowicza okazało się dla niego kluczem do rzeczywistości i pogodzenia z sobą samym, tak twórczość autora Rodzinnej Europy uruchamiała swoisty „mechanizm pamięci” i uzupełniała wytrącone z niej fragmenty dzieciństwa, wyrównywała przeróżne skrzywienia, spowodowane neurozą najmłodszych lat. Dzięki Miłoszowi przeszłość prywatna stała się dla Jeleńskiego obecna. W jednym z jego listów do autora Zniewolonego umystu odnajdujemy bardzo osobisty fragment:

Właściwie żyłem zawsze (podobnie zresztą jak moja matka, która mnie opuściła kiedy miałem 6 tygodni - a poznałem ją dopiero kiedy miałem 4 lata) chwilą obecną - moja świadomość to coś w rodzaju tej tabliczki woskowej, którą tak kochałem kiedy byłem mały — ściera natychmiast każdy zapis ${ }^{61}$.

${ }^{57}$ Tenże, Listy z Korsyki..., s. 53.

58 A. Fiut, Rozmowy z Czesławem Miłoszem, Kraków 1981, E. Czarnecka, Podróżny świata. Rozmowy z Czestawem Mitoszem. Komentarze, New York 1983.

${ }^{59}$ K. A. Jeleński, Jestem Miłoszem, Miłoszem być mogę..., [w:] CO, s. 347.

${ }^{60}$ Tenże, Z listów do Czestawa Miłosza, (1995), s. 76.

${ }^{61}$ Tamże, s. 82. 
Poezja Miłosza była dla niego jedyną, która żyje „kosmicznym rokiem”, tak jakby przez autora przemawiała ,pamięć jednostki, pamięć ludzi, pamięć smoków, pamięć Ziemi”" ${ }^{\prime 2}$.

Przyjaźń ta musiała również oznaczać intelektualne wyzwanie, uzupełnienie. W korespondencji odnajdziemy także takie fragmenty:

Właśnie skończyłem lekturę Twej Romantyczności [...] Jakże żałuję, że nie miałem tego spojrzenia na Mickiewicza odczytując uważnie Pana Tadeusza i powracając do niego w ciągu ostatnich dwóch lat (tłumaczyłem na francuski Trans-Atlantyk). [...] Twoje uwagi $[. .$.$] dały mi odpowiedź na Pimkowskie pytanie „dlaczego powinniśmy kochać$ P.T."

albo, co ciekawe:

Twój Szekspir (czy echo Szekspira, które ja w Twoich wierszach słyszę) jest mi bliższe od Szekspira „Gombrowiczowskiego",63.

Być może właśnie to szekspirowskie echo w dziele Miłosza sprawiło, że to zbiór jego wierszy oraz dzieła Szekspira, a nie — jakby mogło się wydawać — teksty Gombrowicza, były jedynymi książkami, które posiadał w trzech egzemplarzach: jeden na nocnym stoliczku w paryskim mieszkaniu, drugi na fermie u brzegów Loary i trzeci w korsykańskim klasztorze, gdzie najczęściej spędzał wakacje. Teksty Miłosza przynosiły oddech, niemal metafizyczny:

Wiem po prostu z doświadczenia, że Miłosza (jak Szekspira) mogę otworzyć na ślepo, a natrafię na ślad, odbicie czy echo czegoś w przestrzeni między „mną” a ,światem”, co nada znaczenie egzystencji, o której wiem skądinąd, że jest pozbawiona jakiegokolwiek sensu $^{64}$.

W eseju o przyjaźni autora Traktatu moralnego ze Stanisławem Vincenzem Jeleński przytacza wypowiedź Miłosza z rozmów z Renatą Gorczyńską. Słowa te stanowią jednocześnie charakterystykę spojrzenia Jeleńskiego:

Obcowanie z Vincenzem stanowiło wielką przyjemność, bo on był zupełnym przeciwieństwem polskości nacjonalistycznej. Przecież mój konflikt polegał w głównym stopniu na konflikcie z polskim nacjonalizmem, bardzo popularnym, zwycięskim, ale były przecież starsze tradycje - Rzeczpospolitej Polskiej, rozmaitych prowincji — i gdyby takich ludzi jak Vincenz było więcej, może wszystko ułożyłoby się inaczej ${ }^{65}$.

Tak jak w przypadku Gombrowicza, fascynacji Miłoszem i jego dziełem Jeleński dawał wyraz nie tylko w tekstach, lecz także we wszelkich działaniach propagujących na różne sposoby jego twórczość. Jako pracownik Kongresu Wolności Kultury — do którego jeszcze wrócimy — Jeleński uruchamiał w tym celu szerokie koneksje. W rozmowie z Barbarą Toruńczyk Jerzy Giedroyc wspomina zasługi Kongresu w popularyzacji osoby i dorobku Miłosza:

Ludzie z Kongresu wylansowali go, ułatwili mu wydanie pierwszych książek na Zachodzie, na przykład ukazanie się po francusku Zniewolonego umystu. Również Prix Européen, nagroda szwajcarska, którą wtedy dostał Miłosz, to było niewątpliwie dzięki

\footnotetext{
${ }^{62}$ Tamże, s. 79.

${ }^{63}$ Oba cytaty za: tamże, s. 75.

${ }^{64} \mathrm{~K}$. A. Jeleński, $O$,Ziemi Ulro” po dwóch latach, s. 9.

${ }^{65}$ Tenże, „Górami w miękkim blasku dnia”. O przyjaźni Czesława Miłosza ze Stanisławem Vincenzem, [w:] CO, s. 379.
} 
ich stosunkom. Trudno powiedzieć, kto był szczególnym dobroczyńcą Miłosza w tym gronie, w zasadzie wszyscy. To była na pewno duża zasługa Jeleńskiego [... $]^{66}$.

Sam Jeleński pisał w liście do Czapskiego z roku 1978:

[...] od roku dużo zrobiłem dla niego, mobilizując wszystkich możliwych znajomych w różnych krajach w sprawie nagrody Nobla, tłumacząc jego wiersze itd. Nie wiem, czy widziałeś numer „La Discordance” z całym rozdziałem o Gombrowiczu z Ziemi Ulro, tekstem Gombra ze Wspomnień polskich i moim wstępem Mitosz et Gombrowicz? Tłumaczenie długiego tekstu Czesława zabrało mi masę pracy, grosza mi za to wydawca nie zapłacił, tak że wszystko to, co robię (choć wiem, że niewiele), jest całkowicie bezinteresowne, tak jak to, co mogłem przez lata zrobić dla Gombrowicza... ${ }^{67}$.

Warto może przy tej okazji także wspomnieć, że grono artystów, którym w ten sposób pomagał Jeleński, było znacznie szersze. Na otrzymanej od Jeleńskiego widokówce Zbigniew Herbert dopisał:

KOT JELŃSKI MÓJ NAJSERDECZNIEJSZY. NAJCZULSZY. ZAWSZE GOTOWY DO POMOCY PRZYJACIEL I DRUH DZIEKI NIEMU. PRZEŻYŁEM. MÓJ. PIERWSZY. SEZON. PARYSKI. W. LATACH. 1958-60. WSPOMAGAŁ. FINANSOWO. Z ZASOBÓW. KONGRESU. WOLNOŚCI. KULTURY [...] ${ }^{68}$.

Do tego typu inicjatyw Jeleńskiego jeszcze wrócimy.

O tym, że w pisarstwie Jeleńskiego stale obecna jest perspektywa genetyczna, którą z kolei przykłada do własnych — przeróżnych — doświadczeń, by swobodnie mówić o sobie, świadczy także szereg innych (pre-)tekstów. Jednym z nich jest reminiscencja o Józefie Michałowskim zatytułowana Ostatni polski encyklopedysta (1957). Co mówi o samym Jeleńskim ten tekst powiemy za moment, warto bowiem pokrótce chociaż zarysować miniaturowy portret Michałowskiego, wyjaśniający być może już na wstępie, dlaczego Jeleński ofiarował mu to pośmiertne wspomnienie.

Hrabia Józef Feliks Michałowski (ur. 1870 w Dobrzechowie, zm. 1956 w Rzymie) należał do znanej arystokratycznej rodziny. Otrzymał bardzo solidne wykształcenie (studiował w Heidelbergu, Oxfordzie i Paryżu, doktorat z prawa uzyskał na Uniwersytecie Jagiellońskim). Rodzina Michałowskich posiadała ogromną bibliotekę, której znaczną część przewiózł on, jeszcze przed wybuchem I wojny światowej, do Florencji, a następnie do Rzymu, gdzie osiedlił się na stałe. Liczący wówczas osiem tysięcy tomów księgozbiór, Michałowski przekazał Polskiej Akademii Umiejętności w Rzymie, na użytek polskich naukowców we Włoszech. Zbiór ten stał się fundamentem powstałej wkrótce Stacji Naukowej PAU, w której pełnił on rolę bibliotekarza i de facto dyrektora tamtejszej Biblioteki, będącej także miejscem schronienia wielu Polaków w czasie II wojny światowej. Po wejściu aliantów do Rzymu, ze względu na sytuację w Polsce, Michałowski oddał Bibliotekę pod protektorat brytyjski. Otwarto wówczas ją dla ogółu czytelników, szczególnie byłych żołnierzy 2. Korpusu. Po wojnie przedstawiciel Polskiej Akademii Umiejętności przejął od Michałowskiego Bibliotekę. W 1951 roku, kiedy powołano Polską Akademię Nauk i rozwiązano Polską Akademię Umiejętności, stacja PAU w Rzymie przejęta została przez Ambasadę PRL. Michałowski spędził ostatnie lata życia niemal w biedzie, utrzymując się dzięki pomocy kilku rodzin arystokratycznych. Spoczywa na Campo Verano. Ufundowana przez niego (pierwsza

${ }^{66}$ B. Toruńczyk, Rozmowy w Maisons-Laffitte, Warszawa 2006, s. 100-101.

${ }^{67}$ K. A. Jeleński, Listy z. Korsyki..., s. 53-54.

${ }^{68}$ Pisownia zachowana. Cyt. za: Z. Herbert, K. A. Jeleński, Kilka listów, Zeszyty Literackie $2004 \mathrm{nr} 85$, s. 133. 
polska w Rzymie) biblioteka liczy obecnie około 35 tys. tomów i jest otwarta dla wszystkich czytelników.

Do czego wykorzystał (w najlepszym tego słowa znaczeniu) Jeleński postać Michałowskiego? W spojrzeniu osobistym, dalekim od powyższej suchej noty biograficznej, ,inną" rodzinną tradycję Michałowskich skontrastował z (znaną przecież mu z autopsji) konwencją „ogłupiającej rodzinnej anegdoty”, „klanowego ezoteryzmu”, „wspominkarstwem, wistem, brydżem i polowaniem płynącym poprzez polskie ziemiaństwo”. Na czym owa „inność” Michałowskich polegała? Ich — nietrwała niestety - tradycja ustna, drobne historyjki, które wspomina Jeleński, nie były bezsensownym upamiętnieniem kolejnych „,zasług” wujów i dziadów — w swoich rodzinnych opowiastkach „Michałowscy zbudowali [...] polski teatr absurdu”. Wyprzedzali teatrzyk Gałczyńskiego, ich humor był jaskółką tego, w czym gustowała potem literacka awangarda. To jednak, towarzysząca żywemu i kreacyjnemu humorowi Michałowskiego, wrodzona kultura i niespotykana dyscyplina naukowa, która, w swym respekcie dla rzetelności często okazywała się wręcz paraliżująca, była powodem wielkiego podziwu ze strony Jeleńskiego. Naukowa sumienność uczyniła Michałowskiego człowiekiem, który — dosłownie — żył z książkami. Gdy po wojnie pozbawiono go stanowiska w placówce, którą sam stworzył, stracił sens życia. Bibliotekę oddał niejako w ręce PRL, nie chcąc mieć z reżimem nic wspólnego.

System totalitarny, oparty na kłamstwie, nędzy ludu, policji, łapsach, hipokryzyjnym szowinizmie, kulcie Rosji i nienawiści do Zachodu, łączył w sobie wszystko to, co było Michałowskiemu najbardziej wstrętne ${ }^{69}$.

W tych słowach ewidentnie pojawia się sam Jeleński — należą do tych, które definiują także i jego światopogląd. Michałowski był konsekwentnym liberałem, żył ideami Wielkiej Rewolucji Francuskiej, o których dobrze wiedział, że w Polsce nigdy nie były realizowane. Z Jeleńskim zbliżał go także antynacjonalizm i w konsekwencji oczywiście niechęć wobec endecji. Co ciekawe, nie cierpiał Piłsudskiego — ,zdrajcy socjalizmu", wobec którego Jeleński także miał szereg zastrzeżeń. Michałowskiego Jeleński pamięta również jako „ekscentryka, dyletanta i erudytę” — jestem pewien, że dziś wielu tak mogłoby również wspominać jego samego.

Śledząc teksty Jeleńskiego w poszukiwaniu przebłysków światopoglądu, natrafiamy także na te odwołujące się do tradycji, których nie chciał uznawać za jemu bliskie. Okazuje się jednak, że i pośród nich odnajduje reprezentantów, których darzy wielkim szacunkiem. Tak jest w przypadku — spokrewnionej z Jeleńskim - Janiny z Puttkamerów Żółtowskiej, „świadomej konserwatystki”, o której wspomnieniach zatytułowanych Inne czasy, inni ludzie, Jeleński napisał: ,jedna z najciekawszych — i piękniejszych - książek polskich wydanych po wojnie" ${ }^{\text {"70 }}$. To, co przede wszystkim urzeka Jeleńskiego w lekturze, to pełna otwartość autorki, która nie boi się naruszyć zastygłych konwenansów swojego środowiska i demaskuje je bez ,,przesadnej dyskrecji”. W liście do Jerzego Giedroycia, anonsując nadesłanie recenzji tej książki, wyjaśnia:

Niech Pan nie myśli, że gra tu jedynie rodzinna sztama (J.Ż. co prawda prosi mnie o ten artykuł), uważam, że jest to świetna książka, i mimo woli bardzo niekonwencjonalna. Chcę ją potraktować z punktu widzenia socjologicznego, jako najlepszą ilustrację do Genealogii spotecznej polskiej inteligencji Chałasińskiego. Nie ma chyba w polskiej li-

${ }^{69}$ K. A. Jeleński, Ostatni polski encyklopedysta. Wspomnienie o Józefie Michałowskim, [w:] CO, s. 58.

${ }^{70}$ Tenże, Sielskie, anielskie?, [w:] CO, s. 61. 
teraturze bardziej realistycznego (i okrutnego) wizerunku bogatej szlachty kresowej na przełomie stuleci ${ }^{71}$.

Tradycja, którą opisuje, jest dokładnie tą, której przeciwstawił Jeleński kulturę Michałowskich. Zamożna kresowa szlachta, o wielkich wówczas wpływach politycznych i bardzo znaczącej roli społecznej, żyjąca — niekiedy na pewno na poły cynicznie iluzją wytwarzanej przez siebie rzeczywistości. „Reakcjonistka”, jak nazywa autorkę Jeleński (zaznaczając, że określenie to nie jest w żaden sposób w jej przypadku obraźliwe), przywołuje wiernie obraz swojego środowiska, często w sposób „bezlitosny”. Jest — co cenił najbardziej — poszukiwaczką prawdy, odrzucającą hipokryzję otaczającego ją światka. Jej tradycjonalizm nie powoduje (co nie zawsze bywa oczywiste), że jej wizja jest spaczona, że widzi ona jedną wyłącznie stronę medalu. Wyraźnie uwiera ją konwencja polskiego dworu, ukrywany za grzecznościową formułą i cukierkowym banałem permanentny stan rywalizacji, zazdrości i zwyczajnej obłudy. Ta pięknie opakowana fikcja, którą tak wielu z dumą upamiętnia, w książce Żółtowskiej ukazuje dzięki świadomej autorce — swoje prawdziwe, puste oblicze:

W środowisku, w którym główną bodaj cechą było tanie patriotyczne zakłamanie, idealizacja własnych interesów klasowych, tego rodzaju naturalny odruch jest orzeźwiający. Właśnie dlatego, że mała Jania Puttkamerówna z zapałem czytała salonowe powieści francuskie i angielskie, że marzyła o młodych lordach i eleganckich vicomtes, że aspiracje jej do towarzyskiej kultury, zbytku, elegancji zbliżały ją do zachodniej burżuazji, potrafiła przenikliwym, bezlitosnym spojrzeniem dziecka obnażyć istotne motywy postępowania swych bliskich, żyjących złudzeniami „służby narodowi”, płytkiej religijności, lepkiej mazi „poczciwości"72.

Fałszywe byłoby jednak ukazanie Jeleńskiego, jako czerpiącego przyjemność tylko z książek niosących jednostronną krytykę kultury szlacheckich dworków. Choć jako żywo jego stosunek do szeroko rozumianej tradycji był zawsze krytyczny ${ }^{73}$, nigdy nie postulował całkowitego odrzucenia jej dorobku, wręcz przeciwnie. Uważał, że trzeba ją przetwarzać, twórczo kontynuować, rozwijać, być w stałej z nią korespondencji i na jej bazie tworzyć coś nowego. Stąd być może jego wyrozumiałość także dla tekstów, które podejmują momentami próbę obrony związanych z tą kulturą zachowań.

Jakże ciekawą socjologicznie obserwację umieszcza Jeleński na początku drobnej recenzji Europy w rodzinie (Paryż 1970) autorstwa Marii Czapskiej — siostry Józefa Czapskiego, jednego z najbliższych swoich przyjaciół:

Dwór to codziennie przeżywany kontrast pomiędzy dobrocią, ciepłem, delikatnością w salonie a praniem po pysku chłopa, którego krowa weszła w szkodę w polu. Jak można czytać Maeterlincka i grać na fortepianie Debussy'ego, zachowując konieczną w tych warunkach postawę bezwzględnej brutalności? ${ }^{74}$

Jeleński wspomina o podziale ról, przyjmowanych odpowiednio przez mężczyzn i kobiety — ról, które miały okazać się pomocą w połączeniu owych dworskich „obowiązków”. Sytuacja była rzeczywiście dość niewygodna, literatura radziła sobie z nią kon-

${ }^{71}$ J. Giedroyc, K. A. Jeleński, Listy 1950-1987, oprac. W. Karpiński, Warszawa 1995, s. 317.

${ }^{72}$ K. A. Jeleński, Sielskie, anielskie?, s. 64.

${ }^{73}$ Znamienny jest tu także stosunek Jeleńskiego do dwudziestolecia. Raziły go próby idealizacji tego okresu, obce były mu także próby jego rehabilitacji, podejmowane wówczas przez niektórych w kraju.

${ }^{74}$ K. A. Jeleński, Dziat wód, [w:] CO, s. 92. 
wencjonalnie, a więc ostrożnie. W spojrzeniu Czapskiej Jeleńskiemu odpowiada to, że jest „równie świadoma krzywd klasowych, jak indywidualnych zalet «krzywdzicieli» " ${ }^{, 75}$. Na kolejnych stronach odnajduje on swoich dalekich krewnych, wizja ziemiaństwa pokrywa się z tą, którą rysował mu ojciec. Książka Czapskiej przynosi jednak zrozumienie dla pewnych konwenansów, które we wspomnieniach Żółtowskiej są poddane jednoznacznej krytyce, stąd obie lektury określa on jako „symetrycznie przeciwstawne". I choć obie są owym konwencjom oczywiście przeciwne, to Czapska, na modłę „niemal marksistowską”, tłumaczy świadomość jako determinowaną bytem. Taki był czas i tak się żyło — zdaje się mówić. Jest to dla Jeleńskiego spojrzenie nowe, nie kategoryczne, utrzymane $\mathrm{w}$ duchu — tak charakterystycznej dla niego samego — wyrozumiałości.

Jak już zostało powiedziane, dobór postaci, o których Jeleński wspomina w swych esejach, jest nieprzypadkowy. Uwadze polecić warto także fakt, że wybór konkretnych sylwetek przemyca już pewną informację implikowaną o nim samym, że w postaciach przywoływanych są przeważnie drobne cząstki jego samego, cząstki czegoś znanego/ poznanego:

Krytyka w ogóle, a zwłaszcza jak ją rozumie Jeleński, jest przede wszystkim twórczym dopisaniem rodowodu: człowieka, dzieła, myśli, formacji społecznej, prądów artystycznych. Poetycka heraldyka: w artystycznym skrócie komponująca nowe quartiers de noblesse, symboliczne wizerunki utrwalonych w czasie związków jednostki z otoczeniem. Wizerunki te powinny być zrozumiałe i prawdziwe, ukazywać swoistość, odsłaniać uproszczenia, sugerować powinowactwa z wyboru. Można tego dokonać celniej w odniesieniu do zjawisk bliskich, znanych z dzieciństwa, drażniących pretensjami, dziwiących skrytym bogactwem odcieni - dobrym i złym ${ }^{76}$.

Kolejną postacią, którą Jeleński przywołuje w swych tekstach „wizerunkowych” jest Józef Retinger, literaturoznawca i pisarz, cichociemny i wolnomularz, znany jednak przede wszystkim jako polityk, a w tej roli jako doradca generała Władysława Sikorskiego podczas wojny. Jeleńskiemu bliski jest jako pionier wizji zjednoczonej Europy. Był przy tym Retinger bardzo oddany sprawie polskiej. Jeleński podkreśla jego odwagę, lojalność, bezinteresowność.

Pasja czynu, niepohamowana żądza nie władzy, ale wpływu na wypadki, pogarda jaką odczuwał dla tytułów, odznaczeń i honorów, predestynowały go do roli szarej eminencji ${ }^{77}$.

Typ, który Jeleński cenił bardzo wysoko - człowieka pozostającego niejako na uboczu, kogoś niekoniecznie z pierwszych stron gazet, patriotę, który nie musi się deklarować, bo czynami udowadnia swoje oddanie. W takim cieniu przez całe życie pozostawał sam Jeleński, właściwie z wyboru. Poświęcił wiele czasu i sił na walkę o innych (do czego jeszcze wrócimy). Żył dla Polski i dla Europy, marzyła mu się jedność ponad podziałami. O Retingerze — w 1961 roku [!] — pisał:

Dziś, kiedy świat zachodni z wolna idzie w kierunku form organizacyjnych wybiegających poza tradycyjną suwerenność narodową, Retinger wydaje się prawdziwym prekursorem. Nie był on nigdy abstrakcyjnym internacjonalistą. To, czego zawsze szukał - to nie idealnej Paneuropy, ale zasady integracji ponadnarodowej, federalnej, która by gwarantowała prawa nie tylko istniejących narodów, ale także każdej kolejnej grupy dążącej do swobodnego rozwoju. Zawsze przeciwny dyktaturom, Retinger nie zadowalał się

\footnotetext{
${ }^{75}$ Tamże, s. 93.

${ }^{76}$ W. Karpiński, Szkice Jeleńskiego, [w:] tegoż, Książki zbójeckie, Lublin 2002, s. 215-216.

${ }^{77}$ K. A. Jeleński, Prekursor anachroniczny, [w:] CO, s. 69.
} 
ideologią liberalną i parlamentarną. Rozumiał nowe struktury społeczeństwa przemysłowego i o międzynarodową współpracę, o system demokratyczny walczył przede wszystkim w ramach związków zawodowych ${ }^{78}$.

W podobnym duchu, z podziwem dla osoby oddanej słusznej sprawie, pisał Jeleński o Adamie Ciołkoszu, przy okazji wydania jego książki Walka o prawdę. Wybór artykułów 1940-1978 (Londyn 1983). Jeleński dobrze znał przeszłość Ciołkosza, jego związki z ruchem socjalistycznym. Zwraca jednak uwagę, że - co ciekawe - teksty Ciołkosza miały poniekąd charakter religijny, jako że ich autor był szczerze przekonany o chrześcijańskich źródłach socjalizmu, stanowiącego wartość realną, będącego czymś więcej niż jedynie piękną ideą.

Identyfikacja z ludzką krzywdą i nigdy nie przesłonięte doktryną żywe poczucie rzeczywistości są istotnie wspólnym mianownikiem tych tekstów Ciołkosza — „socjalisty konkretnego,"

Wyrozumiale pisze także Jeleński o jego skłonności do idealizacji przedwojennej Polski, co staje się zrozumiałe w kontekście roli przewodniczącego Egzekutywy Zjednoczenia Narodowego w Londynie, jaką pełnił Ciołkosz.

Zna także dobrze Jeleński koleje losu Kazimierza Brandysa, o którym, w posłowiu do niemieckiego wydania Miesięcy pisze:

Podobnie do wielu polskich pisarzy z przedwojennej lewicy, których pierwsza młodość upłynęła w Polsce, od śmierci Piłsudskiego coraz bardziej zagrożonej wzrastającą siłą szowinistycznych i faszysyzujących bojówek, a później w piekle niemieckiej okupacji, wstąpił on do partii komunistycznej skoro tylko zdobyła ona władzę i poddał się dogmatom realizmu socjalistycznego od chwili, gdy stały się, w r. 1949, obowiązujące i to w najlepszej wierze (czy jakby dziś może powiedział — ,w najlepszej złej wierze") $)^{80}$.

Dodaje też o Brandysie słowa bardzo istotne: ,nie dał się nigdy zniewolić do pisarstwa «jednowymiarowego»".

Ciekawe, i warte być może wspomnienia w tym miejscu, jest podejście Jeleńskiego do socrealizmu, którego z góry nigdy nie przekreślał, choć miał świadomość, że przekonująca artystycznie realizacja tej ,metody twórczej” nie jest łatwa. W tekście $O$ realizmie na tle Mezzogiorna (1957), recenzującym dwie książki o Włoszech, będącym w istocie przyczynkiem do szerszej refleksji na temat realizmu w powieści, pisze, że

nic nie stało teoretycznie na przeszkodzie powstania wielkiego dzieła literackiego, poddanego ścisłej dyscyplinie socrealizmu czy nawet żdanowizmu. Wystarczyłoby, aby pisarz głęboko przeżywający prywatny konflikt psychiczny o charakterze manichejskim dokonał świadomie transferu na obowiązujący politycznie schemat. Nie chodziłoby tu bynajmniej o ,ketman” — o przemycanie ,własnych” opinii czy o ,,szczerość w nieszczerości”, ale niemal przeciwnie, o przyjęcie bez najmniejszych restrykcji narzuconego schematu, traktując go jak igraszkę formalną, potrójną jedność tragedii klasycznej czy ramy sonetu. Niestety, czy może raczej na szczęście, schizofrenia prywatna potrzebuje widać formy własnej, jedynej i niezastąpionej i nie potrafi nagiąc się do form schizofrenii zbiorowej ${ }^{81}$.

\footnotetext{
${ }^{78}$ Tamże, s. 72.

${ }^{79}$ K. A. Jeleński, Adam Ciołkosz: socjalista konkretny, Zeszyty Literackie 1985 nr 10, s. 141.

${ }^{80}$ Tenże, Jak można być Polakiem?, Zeszyty Literackie 1985 nr 9, s. 141.

${ }^{81}$ Tenże, $O$ realizmie na tle Mezzogiorna, [w:] CO, s. 183.
} 
Zatem z jednej strony „wystarczyłoby” przyłożyć własny konflikt psychiczny do narzuconej metody, z drugiej jednak Jeleński zdaje się wątpić w realne powodzenie takiego zabiegu. Nie jest to jednak krytyka realizmu socjalistycznego jako prowadzącego koniecznie do literackiej klęski. Jeleński asekuracyjnie daje mu szansę, mówi przecież, że „teoretycznie” był to gatunek jak wszystkie inne — w praktyce jednak okazuje się zawodzić.

Światopogląd Brandysa jest bardzo bliski Jeleńskiemu. We wspominanym posłowiu do jego książki przywołuje słowa pisarza, w których odnajduje także i swoją obawę:

Nic nie napełnia mnie tak silnym lękiem jak Polska głupia i ciemna. Teraz wyrastają znowu, jak spod ziemi, stare upiory szowinizmu i fanatycznej ksenofobii. [...] Można jednak umacniać się pewnością, że czas nada kształt rzeczom. Po latach wszystko się wyjaśni - w kulturze. Kultura ma wyższą mądrość niż historia: potrafi nie tylko interpretować fakty, przyznaje rangę wartościom. Nietolerancja, głupota i ciemność nieraz zalewały polską rzeczywistość, ale kultury narodowej nie tworzyły nigdy. W tym jej wielkość ${ }^{82}$.

W zapiskach Brandysa widzi Jeleński kontynuację analizy rozpoczętej trzy dekady wcześniej przez Miłosza w Zniewolonym umyśle, stąd być może także szacunek, jakim obdarzył autora, który — poszukując prawdy — nie zamiata faktów pod dywan. O Miesiacach napisze jeszcze:

Główny temat tej książki [...] stanowi przedłużenie ostatniej powieści Brandysa, Nierzeczywistość, gdzie już chodziło o sporządzenie archeologii czy genealogii polskiej inteligencji w jej zmaganiach z historią od ubiegłego stulecia po dzień dzisiejszy ${ }^{83}$.

Uczciwe rekonstruowanie tej genealogii było także dziełem Jeleńskiego.

Tekstem, który być może najdobitniej świadczy o swoistym doborze dzieł, jakiego dokonywał Jeleński, jest esej Trzy pory roku Kazimierza Wierzyńskiego (1961). Co w nim tak symptomatycznego? Otóż w szkicu tym Jeleński przyznaje od razu, że w twórczości Wierzyńskiego interesuje go przede wszystkim jej część powojenna, a więc ta wkraczająca w rejony filozofii i traktująca o doświadczeniu egzystencjalnym. Wiersze młodzieńcze, figlarne, jako naiwne, a także tę część z dorobku późniejszego, która odznacza się przesadną retorycznością — odrzuca:

Wczesny Wierzyński interesuje mnie głównie jako świadek epoki; jako zjawisko historyczno-socjologiczne. Pasjonuje mnie natomiast sekret późnego rozkwitu i pogłębienia jego wizji poetyckiej ${ }^{84}$.

U Wierzyńskiego Jeleński afirmuje jedynie te elementy, które jemu samemu są bliskie — ale ich artystyczną przewagę oczywiście argumentuje.

Wspominane powyżej komentarze Jeleńskiego do jego lektur i noty poświęcone ludziom, których szanował, sporo mówią nam o ich autorze: portrecistę zdradza meto-

${ }^{82}$ K. A. Jeleński, Jak można być Polakiem?, s. 143.

${ }^{83}$ Tamże, s. 140.

${ }^{84}$ K. A. Jeleński, Trzy pory roku Kazimierza Wierzyńskiego, ZO II, s. 21. W liście do Jerzego Giedroycia Jeleński pisał z Korsyki: „Dla «Kultury» z tego pobytu urodzi się tylko artykuł o Wierzyńskim, nad którym poważnie od paru dni pracuję. Wierzyński nie będzie niestety z niego zadowolony - może będzie żałował, że tak o to prosił i nalegał. Myślę za to, że artykuł będzie ciekawy i że Pan będzie z niego zadowolony. Zaczyna się sporym wstępem na temat «Skamandra» w ogóle, potem o Wierzyńskim w trzech częściach. [...] Piszę właściwie, że poza drobną częścią udanej, bardzo wczesnej twórczości, Wierzyński stał się poetą dopiero od paru lat”; J. Giedroyc, K. A. Jeleński, Listy..., s. 332-333. 
da portretowania. W opisywanych dziełach odnajdywał cząstki siebie i choć często pisał o osobach wyjątkowo mu bliskich, zawsze udawało mu się utrzymywać suwerenność własnego poglądu.

Jeleński miał wielu przyjaciół. Część z nich była artystami, z częścią łączyły go wspólne życiowe doświadczenia, kiedy indziej upodobania estetyczne, często jedno i drugie. Terenem, na którym odnajdywał fragmenty „własnych zachwytów”, jak już zostało powiedziane, nie była jedynie literatura. Dzieła sztuk plastycznych były także tym wyrazem osobowości, z którym często potrafił się utożsamiać. Jako znawca i entuzjasta sztuki bacznie się jej przyglądał, komentował ją, a swoich ulubionych artystów cenił przede wszystkim za wizję prawdziwą, nierzadko dramatyczną, nieskalaną modnymi stylizacjami.

\section{Nieskończona odkrywczość}

Liczne wypowiedzi Jeleńskiego o sztuce są dla nas kolejną wskazówką — bardzo istotną przy rekonstrukcji jego ogólnego spojrzenia na świat.

Zaciekawienie Jeleńskiego malarstwem sięga co najmniej lat przedwojennych. Jak wspomina Jan Lebenstein:

Kot, poza wieloma innymi sprawami, interesował się malarstwem zawsze, od wczesnej młodości. Jeszcze przed wojną, gdy bywał z wizytą u ojca, konsula w Monachium, zaglądał do Pinakoteki. Potrafił znaleźć czas na chodzenie po galeriach w Londynie w 1941. Jest to zadziwiające, bo jednak jest wojna, młody człowiek ma swoich lat dziewiętnaście, wali się świat, dzieją się rzeczy naprawdę niezwykłe. On jednak przy całym zaangażowaniu znajduje czas na zainteresowanie malarstwem i, wydaje się, to się u niego pogłębia po wojnie, we Włoszech, gdzie mieszkał aż do przeniesienia się do Paryża w $1952^{85}$.

Na fenomen Jeleńskiego jako krytyka sztuki składa się wiele elementów. Po pierwsze warto podkreślić, że nie miał on w tej dziedzinie wykształcenia akademickiego. W jego esejach o malarstwie nie pojawiał się żargon, nieraz ujednolicający recenzje krytyków, posiadających zawodowy warsztat. Dla niego liczyło się osobiste odczucie, które nie podlegało modom, naciskom, a często było im wręcz przeciwne. Kolejną cechą znamienną była zdolność do celnej zwięzłości. Jego teksty o sztuce nie były rozbudowanymi ekfrazami — taki opis nie był dla niego istotny — dzieło było pretekstem. Chciał przy tym uchwycić ten pierwiastek, który odpowiadał za indywidualność artysty, za jego odrębność. Punkty te wyłuskiwał często przy pomocy swoistych skrótów, którymi operował. I to, co być może było dla jego krytyki najbardziej charakterystyczne, zarówno w przypadku malarstwa, jak i literatury - stałe szukanie człowieka i konkretnej rzeczywistości.

W tym wykrywaniu rzeczywistości danego malarstwa Kot miał, to prawda, wielką intuicję - wspomina Lebenstein. - Główne jednak było to, że miał trzeźwy umysł. Miłosz powiedział gdzieś, że Kot miał formację osiemnastowieczną. To polegało na tym, że on przesiewał krytycznie rzeczy, które do niego docierały. W gruncie rzeczy, pomimo, że był bardzo uczuciowy, Kot był człowiekiem bardzo analitycznym. Mnie się zdaje, że stąd brała się jego pasja do krytyki. Ta jego pasja to jednak ciągle analiza, chęć zrozumienia, dotarcia... On nie czytał książki, on ją rozumial ${ }^{86}$.

${ }^{85}$ Rozmowa z Janem Lebensteinem o Kocie Jeleńskim (rozmowę przeprowadził P. Kłoczowski), Zeszyty Literackie $1990 \mathrm{nr}$ 32, s. 110.

${ }^{86}$ Tamże, s. 112. 
Sztuka pasjonowała Jeleńskiego, ale fascynowała go też sama postać twórcy, który był za nią odpowiedzialny. W swoich poszukiwaniach odkrywał często artystów, będących daleko od głównego nurtu, ukrytych gdzieś na uboczu panującego trendu. Pisał o (wówczas) nieznanych i doceniał na wiele lat przed ich sukcesem (np. Fuchsa, Kubina, Klimta, Schielego). Poza tym, jako społecznik z powołania, często pomagał — miał przecież dojścia do różnych funduszy. Robił to zupełnie bezinteresownie, najczęściej anonimowo, nie przyjmował nawet (bądź bardzo rzadko) obrazów od samych artystów. Miał kilka, które traktował jak powietrze, nie jak cenne zdobycze. Nie miał duszy kolekcjonera, nie miał też kompleksów, które mogłyby go skłonić do chwalenia się przedmiotami. Obcował ze sztuką z wewnętrznej potrzeby kontaktu z nią, nie z chęci posiadania. Najważniejsza była dla niego niezależność. Ufał swojej wrażliwości i podążał za intuicją. Czuł swoją odrębność i odrębności innych szukał w sztuce.

To, co zdawało się interesować go szczególnie, to poszukiwanie jakiegoś pomostu między tradycją i sztuką nowoczesną, której poświęcił kilka esejów. Kontestatorskie hasła palenia Luwru, które pojawiły się w Paryżu jeszcze przed awangardą lat 60., były dla Jeleńskiego pociągające - nie interpretował ich jednak jako chęci zrywania z przeszłością. Sztuka nowoczesna, której początek widział w twórczości impresjonistów, nie przynosiła przez lata dzieła „tradycyjnego" — bogata była w prace prowokujące, oparte na różnych konceptach, powstałe często bez użycia malarskiego rzemiosła. Jeleński chciał wierzyć, że jego współczesność też jest w stanie wytworzyć „dzieło”, i na to dzieło czekał. Nowoczesności, która go zachwycała, nie utożsamiał - jak wówczas jeszcze niektórzy — jedynie z Paryżem. W ten sposób przełamywał schematy w jej postrzeganiu. W jego ujęciu, zachowując ciągłość swojej tradycji, powinna być potwierdzeniem różnorodności współczesnego świata. Tę różnorodność — wcale nie paradoksalnie — widział przez pryzmat europejskiej jedności.

Bliska była Jeleńskiemu idea egalitaryzmu. Łączył ją także ze sztuką, wychodząc z założenia, że nadszedł koniec elit, które ustalając kryteria dzieła i jego recepcji są de facto tej sztuki właścicielami. Sztuka — jak twierdził — powinna być dostępna także dla mas ${ }^{87}$. Najjaśniej hasło to zdaje się tłumaczyć esej Pod pretekstem Maneta z roku 1983, napisany także jako odpowiedź na wątpliwości Ewy Bieńkowskiej, dotyczące przesadnych nadziei, jakie Jeleński pokładał w kulturze masowej ${ }^{88}$. Według Bieńkowskiej, na tym etapie rozwoju społeczeństwa konsumpcyjnego, można już śmiało uznać owe nadzieje za złudne. Kultura masowa nie daje — tak jak chcieli jej zwolennicy szerokiego spektrum wyborów w zakresie kultury, gdyż w rezultacie okazuje się, że faktycznie jej wpływ ,,jest skierowany do wewnątrz, czyli zamyka jednostkę w fikcyjnej przestrzeni powielających się wzorów”. Zatem zamiast różnorodności — unifikacja. Jak odpowiada Jeleński? Otóż rozwój społeczeństwa konsumpcyjnego jest dla niego (znów jedynie na pozór paradoksalnie) szansą na sytuację, w której dojdzie do prawdziwego głodu, ,pożądania” kultury. Jeleński, jako „wyczulony na pychę kastową" (co według Bieńkowskiej jest główną przyczyną jego sympatii dla kultury masowej) nie godzi się na „zagrabianie” kultury przez elitę, która sobie jedynie przypisuje do niej prawa ${ }^{89}$. Tę sytuację może zmienić kultura popularna, w ramach której każdy

\footnotetext{
87 Jeleński zdawał się tu zgadzać z Gombrowiczem.

${ }^{88}$ W tekście Sztuka eseju czyli o darze rozmowy Bieńkowska pisze: ,analiza socjologa, który niejako z lotu ptaka cieszy się promocją milionów do wolności, do kultury, zbyt szybko ustępuje postawie entuzjasty"; Aneks 1983 nr 32, s. 109.

${ }^{89} \mathrm{~W}$ pośmiertnym wspomnieniu o Jeleńskim François Bondy podejmuje temat swoistego zwrotu swojego przyjaciela wobec elity, od której jednak, pomimo wielkiego entuzjazmu dla idei
} 
ma dostęp do kultury, mając przy tym świadomość, że zainteresowanie nią nie jest w żadnym stopniu obligatoryjne i nie świadczy o wrażliwości czy inteligencji — Jeleński pragnie uświadamiać: życie bez kultury jest absolutnie możliwe i nie trzeba czuć wobec niej żadnego zobowiązania - owo zobowiązanie leży bowiem u podstaw całego nieporozumienia. Zakłamana elita czuje obowiązek zachwytu, w związku z tym jest on często sztuczny i wymuszony. Kultura jest dla mniejszości — przyznaje Jeleński. Ale jest to mniejszość $\mathrm{z}$ wyboru, a więc grupa, która formuje się z wewnętrznej potrzeby kultury, autentycznego jej „,pożądania”. Wierzy zatem Jeleński, iż otwarcie kultury dla mas (ale nie upowszechnianie na siłę!) spowoduje naturalną selekcję grona, które, w sposób nieprzymuszony, samo zwróci się w jej stronę. Miałoby to zatem przynieść także ulgę socjecie, która do tej pory odczuwała swoisty kulturalny obowiązek. Mówiąc chyba najprościej: nie kultura dla wybranych, a kultura wybrana. Nie byłby jed-

egalitaryzmu, nie mógł kompletnie się odciąć: „Odczytując ponownie teksty Kota na temat społeczeństwa i kultury «masowej», uprzytamniam sobie, że Kot odrzucał z obrzydzeniem wszelki prawicowy elitaryzm i lewicowy snobizm — na równi Ortegę i Marcuse — i śmiał się z przekonania lewicowych intelektualistów - typowego dla Adorno, który się jednak powoływał na co innego — że arystokracja jest swego rodzaju prefiguracją post-burżuazyjnego humanizmu. W swych wspomnieniach z młodości [...] Kot jeszcze ostrzej wypowiada się o domniemanej «dystynkcji» $\mathrm{i}$ «elegancji» tych sfer. Nie wystarczy jednak nienawidzić swych korzeni, by je z siebie wyrwać. Żyd antysemita nie przestaje być Żydem, podobnie Jeleński był kim był nawet jeśli jego «dystynkcja» i «elegancja» wyrażały się inaczej niż w salonowych konwenansach..."; F. Bondy, Kot, Kultura 1987 nr 7/8(478/479), s. 38. Sam Jeleński zdawał sobie sprawę z tego, jak pochodzenie determinowało jego światopogląd. Czuł jednak, że nie może przyjmować tego bezrefleksyjnie, że właściwa droga jest gdzie indziej, że potrzebna jest zmiana: „W Rydzynie, gdzie byłem ostatnie trzy lata przed maturą, dyrektor prosił Mamę, żeby mnie stamtąd zabrała. «Jak to? - pytała Mama — przecież się dobrze uczy, ma dobre stopnie, jest lubiany?». «Tak, proszę Pani — odparł zakłopotany Dyrektor — toteż wyrzucić go nie możemy. Ale my, proszę Pani, staramy się hodować, powiedzmy, białe kury. A Pani kurczę jest czarne, bardzo rasowe, ale czarne». Od dziecka miałem właściwie tylko jedną pasję moralną — egalitaryzm. Trudność polegała na tym, że wszystkie moje kryteria naturalne były estetyczne («arystokratyczne»). Dopiero ta generacja obecna spełnia moje marzenie - elegancja (wyższość) przestała mieć cokolwiek wspólnego z «klasą», «pochodzeniem», wychowaniem, a nawet wykształceniem. Elegancja jest dla mnie, oczywiście, nie tylko fizyczna - oznacza ona spontaniczność, naturalność, życzliwość, wyobraźnię"; K. A. Jeleński, Listy z Korsyki..., s. 44. W jednym z artykułów Jeleńskiego dla „Preuves” odnajdujemy ciekawy krytyczny fragment, dotyczący arystokracji: „Członkowie drobnego ziemiaństwa równie często występowali z oskarżeniami swojej klasy społecznej, co burżuazja — dlatego chyba, że idzie o podobne przywary i że łatwo jest w końcu buntować się przeciw samozadowoleniu, meskinerii, hipokryzji. Wielka arystokracja feudalna wydaje się przynależeć do mitologii bardziej jakoś sympatycznej. Poczuwa się do braterstwa $\mathrm{z}$ «ludem», jest jego sojusznikiem w walce ze strasznymi mieszczanami. Powiada się nam, że «wielkiego pana» odróżnia się po niezwykłej i tajemniczej «swobodzie», pozwalającej mu na komunikowanie się z każdym człowiekiem. Jakby chodziło o przebranych Olimpijczyków, wizytujących nasz ziemski padół. Jeśli wulgarność polega na poczuciu kolektywnej wyższości, to nie ma gorszej wulgarności od arystokratycznej, ponieważ «elegancja» $\mathrm{i}$ «dystynkcja» czynią ją prawie niezauważalną. Owa mitologia jednak zauroczyła wielu ludzi lewicy, dopatrujących się w arystokracji szkicowej (jeszcze niedoskonałej) postaci ludzkości postrewolucyjnej. Przynajmniej tak się tłumaczą ze swoich snobizmów”; zob.: K. A. Jeleński, Fénéon: le critique et l'amateur, Preuves 1967 nr 191, s. 86-89, tenże, Le guépard tombé en poussière, Preuves 1959 nr 97, s. 104-105; tu cyt. za: K. A. Jeleński, Notatki btyskawiczne (Feneon: krytyk i amator oraz Gepard w proch obrócony — oba teksty w przekładzie J. Lisowskiego (Zeszyty Literackie 1992 nr 40 s. 114-117 i 118-121). 
nak Jeleński sobą, gdyby swojej deklaracji (której zawsze unikał) nie opatrzył drobną wątpliwością, dotyczącą jednak zaledwie wycinka kultury i niepodważającą jego teorii:

[...] w przeciwieństwie do muzyki czy do literatury prawdziwy gust do malarstwa, prawdziwe jego pożądanie to przywilej samych malarzy, ludzi, którzy przynajmniej kiedyś chcieli być malarzami czy mogliby nimi być, nie wiedząc o tym, lub tych, którzy - jak Vladimir Nabokov — są wciąż czujni na figle fizjologii wzroku i jej niespodziewane dary ${ }^{90}$.

$\mathrm{Z}$ opisaną powyżej teorią idealnie koresponduje odczyt Jamesa Whistlera, przytoczony we fragmencie przez Jeleńskiego w króciutkim tekście „Ten O’Clock” pana Whistlera (1983). Jeleński wykorzystuje głos Whistlera, jak możemy chyba zasadnie przypuszczać, do wyrażenia także i swojego punktu widzenia. Whistler mówi bowiem (w 1885 roku!), że sztuka staje się dowodem wyrafinowania. Zmusza się ludzi do uznawania jej, dając przy tym konkretne wskazówki, jak to robić - łączy się sztukę z edukacją, przekonując, że czyni człowieka „lepszym”. Jeleński przywołuje jego słowa:

Tymczasem grzeczność, dobre ułożenie, kultura nic ze sztuką nie mają wspólnego, a skądinąd nie sposób największemu uczonemu ani nieposzlakowanemu światowcowi mieć za złe, że nie widzą malarstwa czy nie słyszą muzyki [...]. Ale niech mają na tyle inteligencji, by to wyznać i nie uważać tego za w jakiejkolwiek mierze poniżające.

Sztuka dzieje się przypadkiem — żadna spelunka nie jest dla niej zamknięta, żaden książę nie może na nią liczyć, najwybitniejsza inteligencja jej nie stworzy, a wątłe wysiłki, by ją upowszechnić, skazane są na przemienienie w farsę lub pretensjonalnośćc ${ }^{11}$.

Mówiąc o Jeleńskiego wypowiedziach o sztuce, wspomnieć trzeba przede wszystkim o wątku sztuki współczesnej, której był wnikliwym obserwatorem i komentatorem. W eseju Abstrakcja i „nieprzedmiotowość” (1953), na marginesie artykułu Jana Ulatowskiego Wystawy paryskie ${ }^{92}$, dość wyraźnie wyraża swoje stanowisko wobec malarstwa abstrakcyjnego. Po pierwsze zauważa pułapkę, w którą łatwo wpaść, używając terminu „malarstwo abstrakcyjne”, kojarząc je (jak to robi i Ulatowski) z malarstwem, które - mówiąc najprościej — odcięło się od przedmiotu. Sztuka, jako egzystująca na przeciwnym biegunie w stosunku do konkretnej przyrody i historii, jest przecież zawsze „abstrakcyjna” - mówi Jeleński. Stąd trafniejszy zdaje mu się angielski termin non-objective painting, który wyraża właśnie tytułową „nieprzedmiotowość”" ${ }^{3}$, charakteryzującą malarstwo, które, jako odchodzące od „klasycznego” przedstawienia problemu, ,oderwane od techniki porozumiewania się” (jak pisał Ulatowski), zwykliśmy nazywać ,abstrakcyjnym”.

Po ustaleniu należytej terminologii Jeleński, nadal na marginesie tekstu Ulatowskiego, przechodzi do kwestii fundamentalnej (komentowanej zresztą od wieków): czy sztukę można (należy) traktować jako narzędzie poznania? Ulatowski pisze: „Malarz-abstrakcjonista jest [...] poszukiwaczem prawd najtrudniejszych, pewnych [...]"94. $\mathrm{Z}$ takim stanowiskiem nie może zgodzić się Jeleński, upatrując $\mathrm{w}$ malarstwie jedynie zapomnianą w codzienności, zaniedbaną ,poetycką wizję świata”, która, operując

${ }^{90}$ K. A. Jeleński, Pod pretekstem Maneta, [w:] CO, s. 329.

${ }^{91}$ Tenże, ,,Ten O'Clock” pana Whistlera, [w:] CO, s. 331-332.

${ }^{92}$ Kultura 1952 nr 12(62), s. 122-131.

${ }^{93}$ Polskiemu czytelnikowi znany jest zapewne bliżej termin „malarstwa niefiguratywnego” - Jeleński miał skłonność do dosłownego tłumaczenia pojęć z innych języków, pomijając (świadomie bądź nie) przyjęte już terminy polskie.

${ }^{94}$ J. Ulatowski, Wystawy paryskie, s. 130. 
kształtem i kolorem, a więc symbolami, nie może — właściwie z definicji — odkrywać przed odbiorcą jakichkolwiek ,prawd”.

Poprzez malarstwo widzimy często świat po raz pierwszy; malarstwo może nam dać wizję „archetypów” drzemiących na dnie naszej psyche, może być przewodnikiem w poszukiwaniu jądra własnej osobowości; malarstwo może wreszcie czasem dać tę niemal mistyczną iskrę, będącą formą autentycznego istnienia, zatrzymującą falę czasu, która unosi niezliczone i bezwartościowe wcielenia naszego ,ja”. Taką właśnie wizją była dla Prousta żółta ściana Vermeera. Wszędzie działać będzie symbol; i nie widzę, dlaczego rozdrobnienie, rozatomizowanie symbolu, zapożyczenie wizji soczewkom muchy czy nietoperza ma dać symbol prawdziwszy czy głębszy niż operowanie elementami świata na miarę ludzką, wizją ludzkiego oka (jakkolwiek ,zdeformowaną" przez indywidualną wizję artysty) ${ }^{95}$.

Malarstwo „tradycyjne” (tj. ,przedmiotowe”) nie może być formą poznania, lecz jedynie uzewnętrznieniem pewnych subiektywnych drgań wewnętrznych, które, choć mogą oczywiście powstać na skutek percepcji tego, co zewnętrzne, nie mają przecież prawa legitymizować się jako mówiące „prawdę” o owej zewnętrzności, nie mogą się za nią uznawać. Nie inaczej jest oczywiście także z malarstwem, które ,przedmiotu” unika. Nieporozumieniem jest więc dla Jeleńskiego hasło Braque’a, które Ulatowski cytuje jako dyrektywę dla malarzy, stanowiącą dla niego wręcz o statusie malarza: je n'imite pas la nature - je la recommence. Przeświadczenie o możliwości „zaczynania natury od nowa” jest dla Jeleńskiego pomyłką, stąd nie może on oczywiście uznać go za wyróżnik malarstwa.

Nie odmawia Jeleński znaczenia plamom, formom i liniom w naturze, wręcz przeciwnie — jako wielki tropiciel przypadków jest przekonany, że „forma w przyrodzie jest chyba tylko pozornie przypadkowa i nieraz pozwala nam odkryć pewne prawdy (czy złudzenia prawd?)”. I choć w zdaniu tym dwukrotnie się asekuruje, mówiąc „,chyba” i ,złudzenia prawd”, robi to jako człowiek dopuszczający różne możliwości, zdaje się mówić: „może tak jest, może nie, ja w to wierzę, choć naiwnością byłoby upieranie się przy tym”. Owe plamy, formy i linie, muszą być jednak, jak już zostało powiedziane, w stanie ,naturalnym”. W przeciwnym wypadku, przy całej swej efektownej dekoracyjności, przy zabawie i rozrywce, jakiej dostarczają, nie mogą być w żadnym wypadku uznawane za ,poszukujące prawdy”, świadczące o niej. Jeleński nie neguje więc sztuki „nieprzedmiotowej” — jest pewien, że wkrótce znajdzie ona nawet swoje miejsce w historii. Przeciwny jest jednak uznawaniu jej, jak zresztą każdej innej stylizacji, za jedynie prawdziwą, za naturalną, obiektywną rzeczywistość.

Kolejną wątpliwość względem sztuki współczesnej wyraża w tekście $O$ kilku sprzecznościach sztuki nowoczesnej (1963), analizującym przyczyny tryumfu, ale i szybkiego upadku awangardowego malarstwa typu action painting. Esej zawiera bajkę, o szukającym twórczej wolności malarzu współczesnym:

Zrzucił najpierw „temat” (czy „przedmiot”), którego „,namalowanie” dawało przez tak długie wieki „obraz”, zachowując obraz jako przedmiot sam w sobie. Z kolei zrzucił obraz, pozostawiając płótno, służące jeszcze jako materialna podpora egzystencjalnego gestu. Pozbył się płótna dla nagiej, jednolicie niebieskiej czy białej ściany (Yves Klein), gdzie egzystencjalny gest operuje jeszcze kolorem. Ale na co kolor, skoro gest wyboru, decyzji (jedynie ważny) można zadokumentować, ładując do skrzynek ,akumulacje” banalnych, codziennych przedmiotów? Ten powrót „przedmiotu” (na szczęście nienamalowanego) został odczuty jednak jako nowy balast (wynika to choćby z nazwy:

${ }^{95}$ K. A. Jeleński, Abstrakcja i „nieprzedmiotowość”, [w:] CO, s. 171. 
„,neorealizm”), tak że nasz malarz doszedł w końcu do czystego wydarzenia (amerykańskie happenings, będące psychodramatami, tyle że odgrywanymi w galeriach obrazów...).

Tak odciążony, nasz malarz z bajki rozgląda się obecnie za sztalugą, farbami, płótnem. Kto wie, może powróci do obrazu, a nawet do „tematu”, zanim nie odczuje go znów jako balastu ${ }^{96}$.

Jeleński zauważa dwa nurty sztuki współczesnej, które funkcjonują stosunkowo równolegle od początku XX wieku, nazywa je umownie: malarstwo i antymalarstwo. Pierwszy z nich łączy się z hasłem ,czystego malarstwa”, któremu patronuje Cézanne. Malarstwo jest tu pojmowane dosłownie jako malarstwo, zgodnie z definicją Maurice'a Denisa, że obraz, niezależnie od przedmiotu, jaki przedstawia, to przede wszystkim płaszczyzna pokryta kolorami ułożonymi w pewnym porządku ${ }^{97}$. Ujęcie to ignoruje zbędną alchemię, mistyczne poszukiwania — dzieło może być stworzone świadomie, malarstwo to przecież przestrzeń, formy i kolory. Malarz działa tu na rzecz malarstwa, pragnie stworzyć obraz doskonały. Dość szybko okazało się jednak, że artyści, którym przyświecała taka wizja malarstwa, zrezygnowali z przedmiotu, aby zwrócić uwagę na sam układ przestrzenny i kolor. Ale i to „wyzwolenie” okazało się niewystarczające. Zaczął wówczas wykluwać się (przypominać o sobie) drugi nurt, który nie zadowolił się likwidacją tematu. Musiał pozbyć się także i innych elementów: zrezygnować z przestrzeni, układów i kolorów, aby móc nazwać się ,antymalarstwem”. Nurt ten miał być zatem właściwie likwidacją samego malarstwa na rzecz wolności malarza, istotna była tu sama czynność (bądź nawet zamiar) malowania. To malarstwo miało tu służyć artyście, jako dzieło samo w sobie nie było istotne, by nie powiedzieć po prostu, że jako wytwór finalny było malarzowi obojętne - jego znaczenie leżało jedynie w pomocy na drodze artystycznego odkrywania. Z obu nurtów to oczywiście właśnie ten miał swój znaczący wpływ na rozwój abstrakcji, uciekającej od koncepcji malarstwa jako „nieruchomego piękna”. Zaczęto szukać głębiej. Walor estetyczny stracił na znaczeniu - taszyzm począł powoływać się na doświadczenie egzystencjalne i hasła żywej wolności. Stąd płótno miało stać się przeznaczeniem dla zdarzenia, akcji, nie dla odtwarzania przedmiotu. Musiało wiązać się to z problematycznością w zakresie oceny takiego dzieła („dzieła”). Malarstwo to bowiem, abstrahujące od wszelkiego warsztatu, okazywało się wymykać kryteriom estetycznym — wartości jego trzeba było szukać gdzieś poza sztuką, skoro sam obraz to jedynie efekt uboczny poszukiwania siebie poprzez spontaniczne ,akcje”. Przyznawał to sam Harold Rozenberg, amerykański pisarz i krytyk sztuki, autor terminu action painting, którego opinia miała wyjątkowo silny wpływ na światową sztukę współczesną. Jeleński przytacza głośną już odpowiedź Mary McCarthy na słowa Rosenberga: You can't hang event on the wall. Sytuacja, jak zauważa Jeleński, szybko stawała się absurdalna, jako że galerie, muzea, kolekcjonerzy chcieli przecież nadal kupować obrazy, a te de facto okazywały się nie mieć żadnej estetycznej wartości. Kryteria egzystencjalne okazały się „niebezpieczne”, nie dziwne zatem, że coraz częściej zaczęto powracać do definicji Denisa. Tymczasem kolejny ze szczególnie opiniotwórczych krytyków, popularyzator abstrakcjonistów amerykańskich, jako pierwszy chwalący prace Jacksona Pollocka, Clement Greenberg, zauważył, że nowa sztuka ma swoje korzenie chociażby w kubizmie. Pojawił się zatem kolejny problem: czy rzeczywiście sztuka abstrakcyjna, która za wszelką cenę chciała odciąć się od tradycji, zdołała powstać, burząc wszystko to, co ją poprzedzało? Pytanie to

\footnotetext{
${ }^{96}$ Tenże, O kilku sprzecznościach sztuki nowoczesnej, [w:] CO, s. 211-212.

${ }^{97}$ Por.: tamże, s. 212.
} 
stawia Jeleński i zdaje się oczywiście wątpić w odpowiedź twierdzącą. Okazuje się bowiem, że w sztuce tej można znaleźć szereg nawiązań do malarskiej przeszłości.

Oba wspomniane nurty są $\mathrm{w}$ istocie opowiedzeniem się po konkretnej stronie w dyskusji o charakterze „właściwej” sztuki. Pierwszy jest opcją wyrażającą ciągłość tradycji, drugi chce wprowadzić na jej teren kompletną rewolucję, odcinającą jakiekolwiek powiązania z tym, co już znane. Czy to zerwanie jest jednak możliwe? W 1963 roku Jeleński pisał:

Rewolucja sztuki nowoczesnej chciała obalić Estetykę, podobnie jak rewolucja marksistowska chciała obalić Historię. Ale jeśli Historia tak uporczywie trzyma się przy życiu w Związku Sowieckim, może podobnie rzecz ma się z Estetyką, przynajmniej w sensie, w którym wydaje się nieodłączną częścią ludzkiego doświadczenia? Sztuka nowoczesna zawiera w sobie tę sprzeczność: powstawszy przeciw sztuce „tradycyjnej”, domagając się, wciąż na nowo, „końca Sztuki”, narzuciła się ona jednocześnie jako jedyna sztuka prawdziwa i trwała. „Koniec Sztuki” — ale tylko zamykając drzwi przeszłości, drzwi przyszłości pozostają otwarte. Rewolucja — ale na stałe ${ }^{98}$.

Rewolucja na stałe? Sprzeczność tę zauważali także niektórzy „rewolucyjni” krytycy. Powrót do dawnego malarstwa jest nieunikniony, bez względu na to, co głoszą rewolucyjne postulaty. Dlatego też dogmat rewolucyjności sztuki abstrakcyjnej (w związku z niemożliwością jego zastosowania) stanowi dla Jeleńskiego o immanentnej w gruncie rzeczy sprzeczności tego nurtu. Ponadto, niektóre nurty sztuki nowoczesnej zwracają same sobą uwagę na swoich poprzedników, a także wzbudzają zainteresowanie tymi obszarami, przedmiotami, które nie były dotąd uznawane za dzieła, otwierając tym samym drogę do uznawania i ich także za ,współczesne” — na przykład:

[...] action painting i abstrakcja liryczna zwróciły zainteresowanie amatorów w kierunku kaligrafii Dalekiego Wschodu, rysunków mistrzów buddyjskiej sekty zen. W ten sposób aureola „,sztuki nowoczesnej” otacza nie tylko dzieła naszego czasu. Rzeźba archaiczna może być dla nas „współczesna”, podobnie jak mozaika bizantyjska; podczas gdy sztuka nowoczesna wchłania również przedmioty, które nigdy nie były pomyślane jako dzieła sztuki, służyły magii czy życiu codziennemu; co więcej, dochodzą do tego przedmioty, które nie są ani ,sztuką”, ani „,dziełem”: kamienie znalezione na plaży, korzenie, kora, dziwaczne odpadki z przemysłowego śmietnika... ${ }^{99}$.

Śledząc sprzeczności sztuki współczesnej Jeleński odwołuje się także do poruszonych w jednym ze swoich wcześniejszych artykułów jej związków z rozwojem społeczeństwa przemysłowego. W swojej eseistycznej recenzji Oka Czapskiego pod tytułem Czyste malarstwo czy poetyka (1960) sztukę współczesną Jeleński interpretuje jako reakcję na

„wyzwanie” rzucone artyście przez socjologiczną mutację, jaką zapowiada społeczeństwo technologiczne [...]. Ta reakcja może być dwojaka: bądź „,pozytywna” (próba integracji społeczeństwa przemysłowego w ramy współczesnej mitologii), bądź „,negatywna” (a w istocie „kompensacyjna”): sztuka jako rezerwat odwiecznych, indywidualnych mitologii w społeczeństwie przemysłowym ${ }^{100}$.

Podejrzewa zatem Jeleński konkretny związek między socjologicznymi przemianami, z jakimi wiąże się rozwój społeczeństwa przemysłowego, a ,rewolucją” artystyczną,

\footnotetext{
98 Tamże, s. 217.

99 Tamże, s. 220.

${ }^{100}$ K. A. Jeleński, Czyste malarstwo czy poetyka, [w:] CO, s. 198.
} 
z którą związane jest hasło „,anty-sztuki”. Abstrakcja byłaby tu widziana oczywiście jako reakcja ,pozytywna”.

Pisząc o wystawie polskich abstrakcjonistów w Paryżu, poświęca fragment własnej ocenie abstrakcji geometrycznej, którą cechują według niego: oschłość, nuda, pedanteria i naiwność ${ }^{101}$. Ewidentnie irytuje go włączanie tego nurtu do historii sztuki, jako że jest to wrażliwość innego typu, a ponadto sami malarze, jak na przykład Malewicz, wcale tego sobie nie życzą. Zarówno Malewicz jak i Strzemiński nie są kontynuatorami abstrakcjonistów i dadaizmu — są anty-sztuką. Jak zwykle zauważa Jeleński pewien paradoks, tym razem w reprezentowanym właśnie przez obu wspomnianych malarzy „geometrycznym epizodzie” ich twórczości:

Widzę w nim [owym epizodzie] marzenie o milenium technologii mechanicznej, naiwną poezję ludzi, którzy w szklanych sześcianach pragnęli zamknąć szklanego człowieka. W tym sensie to malarstwo rzekomo bezprzedmiotowe jest na wskroś symboliczne, najbardziej właśnie literackie, gdyż nic nie reprezentuje w oderwaniu od stworzonej przez jego twórców literatury ${ }^{102}$.

Co więcej, znajduje bardzo ciekawą i nietypową paralelę między sztuką tego typu, a „spłyconym, pojętym mechanicznie” komunizmem: „przecież żaden styl nie jest bliższy mechanicznej koncepcji człowieka od abstrakcji geometrycznej, która eliminuje tajemnice życia organicznego, zawiłe ścieżki, w których może się odnaleźć psychika ludzka" ${ }^{\prime 103}$.

Powracając do związków sztuki z rozkwitem społeczeństwa przemysłowego warto wspomnieć o kolejnej odnotowanej przez Jeleńskiego antynomii. Wykazuje on, że o ile dadaizm i nadrealizm, po pierwszej wojnie ,przemysłowej” lat 1914-1918, a także powstałe na ich gruncie surrealizm i abstrakcja liryczna, miały być pewną formą sprzeciwu (niekoniecznie świadomego) wobec więzów nakładanych przez powstające potęgi technokratyczne, o tyle już pop-art w żaden sposób nie jest wyrazem protestu wobec kultury masowej społeczeństwa przemysłowego, gdyż po prostu z niej wyrasta — jest formą nowej zabawy, rozrywki, urozmaicenia, i choć Jeleński ceni go za autentyzm i dowcip, mówi jasno, że świadczy on przy tym o kryzysie sztuki. Ukazując jej upadek nie ma na myśli jednak śmierci malarstwa w ogóle.

Według Jeleńskiego informel ${ }^{104}$, oddalając się od przedmiotu, chciał jednocześnie zbliżyć się do natury. W tym dążeniu wychwytuje kolejny paradoks: czyż natura nie składa się bowiem z przedmiotów? Co więcej, sztuka ta nie chce twórczo wykorzystywać natury w żaden sposób, lecz tworzyć na podobieństwo zachodzących w niej (tj. naturze) procesów. Ten rodzaj współzawodnictwa jest według Jeleńskiego niemożliwy: sztuka ta nie zbliża się do natury (bo nie jest w stanie), a — jak zauważa — jedynie tworzy na swoją potrzebę kolejną mitologię. Dynamizm natury, jej ruch, praca są niemożliwe do przejęcia przez sztukę — ,jedyną niezastąpioną funkcją malarstwa jest ewokacja jedności nieruchomej". Natura musi być inspiracją dla artysty, nie obiektem rywalizacji:

[...] niezrozumiałe wydaje mi się to dążenie malarzy i rzeźbiarzy do przypadkowego tworzenia rzeczy, które przyroda nieomylnie wyrabia przez lata krążenia organicznych

${ }^{101}$ Zob.: K. A. Jeleński, Tryb zaprzeszty czasu przeszłego, Kultura 1958 nr 1/2(123/124), s. 164.

102 Tamże.

103 Tamże, s. 165. Identyczny fragment odnajdziemy w eseju Awangarda i rewolucja z roku 1960 (ZO II, s. 72).

${ }^{104}$ Dla Jeleńskiego ten termin zdawał się być synonimem taszyzmu. 
soków, przez lata rozkładu, petryfikacji, poprzez całe naturalne laboratorium, z którego wychodzą przedmioty dziwnie czytelne i obarczone naturalnym znaczeniem ${ }^{105}$.

Sprawa warta dla nas pokreślenia: te przekonania Jeleńskiego uświadamiają nam, jak bliski był on malarskiej tradycji.

O jednym z nurtów sztuki nowoczesnej, znanym jako body art, Jeleński wypowiadał się kilkakrotnie - zawsze z charakterystycznym dla siebie krytycznym dystansem. W wypowiedziach tych często powraca do, wspomnianego już, uznania samego aktu twórczego za dzieło - zwrócenia uwagi na elementy, które do tej pory służyły jedynie za materiał dla twórcy, a które, w wizji artystów współczesnych, stały się autonomicznym dziełem:

U źródeł tej „twórczości”106 mamy inwersję pasji moralnej, przekonanie, że nic, co nie jest powszedniością i ciałem, nie może być „autentyczne”. Tworzywem (jeśli można jeszcze użyć tego słowa) jest surowiec pewnych form wrażliwości, będących jednym z ważnych źródeł sztuki. Wrażliwość tę skondensował Gombrowicz w postaci Leona w Kosmosie. Pod pozorami prowincjonalnego ramola mamy tu groźnego demiurga, karykaturalny autoportret autora. Leon umie nadać sakralną siłę dłubaniu w zębie, lepieniu kulek z chleba, wszelkim formom wstydliwego ,gmerania” [...]. Nadanie magicznego znaczenia bulgotom ciała czy obgryzaniu paznokci jest niewątpliwie najniższą forma prywatnego mitu, który wzmacnia się w obsesyjnych rytuałach neurozy i dochodzi do paroksyzmu w psychozach. Paradoksem współczesnej awangardy jest to, że Leon, a nie Gombrowicz, jest dla niej wzorem artysty, dziełem sztuki zaś nie Kosmos czy Ferdydurke, a samo Leonowe ,gmeranie”, gdyż ono jedynie nie kłamie ${ }^{107}$.

Niemal identyczną krytykę odnajdujemy w referacie La nature dans l'homme, który Jeleński wygłosił w ramach Rencontre Internationale w Neuchâtel w Szwajcarii we wrześniu 1973 roku. Ponownie powołuje się na Gombrowicza, który — podobnie jak Kafka, Schulz czy Landolfi — potrafił wykorzystać wstydliwe, związane z ludzką cielesnością elementy, które stale o sobie przypominają, a bywają najczęściej tłumione i skwapliwie maskowane. Gombrowicz umiał posługiwać się nimi, aby na ich bazie tworzyć. Tymczasem:

W jednym z numerów surrealistycznego pisma „Le Minotaure” z 1935 roku Salvador Dali opisuje ,rozkosz intymnej czynności polegającej na wyciskaniu z porów nosa, za pomocą delikatnych choć bolesnych ucisków otaczającej je skóry nowych, ślizgających się, aerodynamicznych wągrów, nazywanych także czarnymi punktami”. Lecz to, co dla artystów było jedynie surowcem, przedstawiane jest przez współczesną awangardę artystyczną jako dzieło sztuki. Już nie idzie o napisanie „Nosa”, wystarczy kichnąć. Już nie idzie o wykorzystanie, w przyszłym dziele sztuki, fascynujących obserwacji intymnych procesów zachodzących w ciele człowieka, wystarczy w galerii sztuki wycisnąć sobie wągra $^{108}$.

Z powyższych fragmentów mogłoby wynikać, że Jeleński był zdeklarowanym przeciwnikiem wszelkich nurtów sztuki współczesnej — wizerunek ten byłby jednak

${ }^{105}$ K. A. Jeleński, Listy z Korsyki..., s. 15.

${ }^{106}$ Wymowny cudzysłów Jeleńskiego.

${ }^{107}$ K. A. Jeleński, Lebenstein - mitotwórca ludzkiej natury, [w:] CO, s. 252.

${ }^{108}$ Referat Jeleńskiego zamieszczony został w tomie: L'Homme moderne et son image de la nature, ed. R. Chenu, Neuchâtel 1974. Cytat podaję za wstępem Piotra Kłoczowskiego do tekstu: K. A. Jeleński, Bioantropologia a kultura wspótczesna, tłum. J. M. Kłoczowski, Kresy 1999 nr 40, s. 192. 
nieprawdziwy. Był jej czułym obserwatorem, wrażliwym na zakłamania i nieporozumienia, potrafił jednak dostrzec $\mathrm{w}$ jej ramach zjawiska, które w jakimś stopniu są w stanie poszerzyć rozumienie, postrzeganie sztuki, a więc tym samym okazują się mieć swój znaczący, pozytywny wpływ na jej recepcję w ogóle. W tekście Aktualność malarstwa Józefa Czapskiego (1984), w którym łączy twórczość swego przyjaciela z dziełami spod znaku pop-artu, odnajdujemy fragment:

[...] jednym z głównych wkładów Pop-Artu do sztuki nowoczesnej jest dopuszczenie do naszej wizji estetycznej ostatnich bodaj przedmiotów i form, które otaczane były po dziś dzień pogardą, dotychczas więzionych w wulgarnym rezerwacie kiczu, sztuki komercjalnej, codziennej prasy ${ }^{109}$.

„Dzieła” sztuki współczesnej posługujące się tego typu przedmiotami powstają bardzo świadomie. Z muzealnych ścian znikają obrazy — pojawiają się różnego rodzaju eksponaty, które imitują najczęściej rekwizyty znane z życia codziennego. Wszystko to w imię nieufności wobec „wyższych" funkcji ludzkich i chęci redukcji człowieka, którego - podkreśla Jeleński — zredukować nie można ${ }^{110}$. Docenia on jednak „nieufność" nurtów współczesnych wtedy, kiedy zwracają się one przeciwko aroganckim artystom, wierzącym w moralizatorską powinność sztuki, i przez to chcących na siłę odciąć się od jej funkcji mitotwórczej — Jeleński wie bowiem dobrze, że niezależnie od intencji, ludzka podświadomość zawsze zachowuje autonomię i jest w stanie przenieść choć cząstkę mitu do dzieła poddanego nawet najbardziej rygorystycznym wymogom formalnym czy treściowym. Niechęć Jeleńskiego do redukcyjnej awangardy wynika z charakterystycznego dla tej grupy pragnienia ucieczki od tego mitu. Ale szczerą nieufność, skierowaną przeciwko sztuce pretensjonalnej z intencji - popierał.

Najbliższa była mu oczywiście propozycja nadrealizmu — dla Bretona, autora Manifestu surrealizmu, zjawiska takie jak wolne skojarzenia, marzenia senne służyły ujawnieniu podświadomości — jej wpływ na życie, a więc i na wyraz artystyczny, o czym mówiliśmy, dostrzegał także Jeleński. W eseju o związkach rewolucji październikowej i sztuki awangardowej — Awangarda i rewolucja (1960) — krytycznie wypowiadając się o abstrakcji geometrycznej, przeciwstawia jej propozycję nadrealistów. Ci, podobnie jak reprezentanci abstrakcji (lecz kilkanaście lat później), utożsamiali się z rewolucją — założenia i podstawy swej identyfikacji rozumieli jednak inaczej:

Przystąpienie nadrealistów do komunizmu było konsekwencją protestu przeciw murom wartości ograniczającym wolność człowieka. Powołali się na Marxa, który zburzył świat wartości, tak jak na Freuda, który starł konwencjonalne pojęcia człowieka o samym sobie. W ich mitologii na ojcowski uśmiech Lenina padał czarny cień Sade'a. Nadrealizm jest jedynym ruchem intelektualnym, który wziął rewolucję na serio, nie mając przy tym złudzeń co do ludzkiej natury. Dla nadrealistów hasło „Wolność” oznaczało naprawdę wolność, nie zaś nową formę porządku. I nic dziwnego, że buntownicza sztuka nadrealistów, godząca w sedno wewnętrznych skrępowań człowieka, była dla komunistów nie do przyjęcia, podobnie jak nie do przyjęcia jest abstrakcyjny wyraz późniejszych nadrealistów, zawsze liryczny i organiczny ${ }^{111}$.

\footnotetext{
${ }^{109}$ K. A. Jeleński, Aktualność malarstwa Józefa Czapskiego, Zeszyty Literackie 1994 nr 45, s. 52.

${ }^{110}$ Por.: K. A. Jeleński, Lebenstein - mitotwórca ludzkiej natury, [w:] CO, s. 248.

${ }^{111}$ K. A. Jeleński, Awangarda i rewolucja, ZO II, s. 72. Odnajdujemy tu także, identyczne jak w eseju Tryb zaprzeszły czasu przeszłego (zob. przypis 101), porównanie: „Żaden styl natomiast nie wydawałby się na pozór bliższy idealistycznej i mechanicznej koncepcji człowieka niż abstrakcja geometryczna, w której nie istnieje tajemnica życia organicznego — labirynt, w któ-
} 
Na zawarte w Ziemi Ulro zarzuty Miłosza, o wspomniane tu odwołania surrealistów do marksizmu i freudyzmu, po niemal dwudziestu latach Jeleński odpowie:

Zapomina [Miłosz], że nawet na wstępnym, ,rewolucyjnym” etapie czynili to w sposób wysoce nieortodoksyjny, niepokojąc i gorsząc strażników obu doktryn. Ja także nigdy nie lubiłem surrealistów jako grupy, ruchu czy wprost mafii za ich rygorystyczne przepisy i zakazy, wydawane w imię utopijnej wolności. Kiedy zbliżyłem się do Maxa Ernsta, Bellmera, Braunera we wczesnych latach pięćdziesiątych, byli już oni przez Bretona ,ekskomunikowani”"112.

W miejscu, w którym mowa o sztuce cenionej przez Jeleńskiego, warto zatrzymać się przy dziele Józefa Czapskiego. Z dystansem pisze Jeleński o malarskiej przedwojennej pasji teoretycznej Czapskiego, który wracając z grupą kapistów z Paryża do Polski na początku lat 30., jak sam pisze - czuł się „,nosicielem prawd absolutnych i elementarnych w malarstwie”. Ową prawdą był dogmat „,czystego malarstwa”, któremu patronował wielbiony przez Czapskiego Cézanne ${ }^{113}$. Tam, gdzie pojawiają się „prawdy absolutne”, musi oczywiście odezwać się podejrzliwe zainteresowanie Jeleńskiego.

Rzecz bardzo interesująca, która wyraża subtelną różnice między Czapskim a Jeleńskim, nie tylko na gruncie sztuki, ale jednocześnie w sferze światopoglądowej: otóż Czapski zauważa pewne analogie pomiędzy stanami uniesień artystycznych, wizjami artysty, a stanami ekstazy o charakterze mistycznym. Mówiąc ,analogie są tak uderzające, wykres stanów tak nieraz identyczny w swych załamaniach i uniesieniach, że najbardziej świecko nastawiony artysta powinien się nad tym zastanowić" ${ }^{114}$, zdaje się sugerować, choć ostrożnie, to jednak dość wyraźnie, że stany te, muszą być powiązane, że ich podobieństwo nie jest przypadkowe - że ich natura jest ta sama. Jest to zrozumiałe dla Jeleńskiego, zdającego sobie sprawę z sakralnej sfery życia, która buntuje się wobec powszedniości i która leży u podstaw różnych form artystycznych. Odmienność ich spojrzeń leży głębiej. Jak zauważa Jeleński, Czapskiemu „nie wystarczyłoby to zaliczenie doświadczenia artystycznego do dziedziny sakralnej ludzkiego istnienia". Powołując się na słowa przyjaciela-malarza, wyczuwa:

Podejrzewam u niego transfer chrześcijańskiej religijności na sztukę. Oto jak odpowiada on na nieco odmienne zresztą sformułowanie Malraux, dla którego „w cywilizacji agnostycznej, «spadkobierczyni wszelkiej wielkości», funkcją zastępczą religii jest wolność twórcza geniuszów-demiurgów".

„Jeżeli sztuka ma wystarczyć, jeżeli będzie neo-religią agnostycznej kultury, jeżeli jest tylko rzuconym w ciemności zapytaniem, na które nie może być odpowiedzi, bo nie ma komu odpowiadać, jeżeli Bach, Rembrandt czy Norwid są tylko zapytaniem, a nie także odpowiedzią, nicią łączącą nas z doświadczeniem innego wymiaru, o którym nawet Proust pisze w swych stronach o śmierci Bergotte'a — sztuka jest wtedy, jak wszystko w życiu, mówiąc językiem Kiriłowa z Biesów «diabelskim wodewilem»”.

rym człowiek może się starać odszukać samego siebie. Żaden styl nie jest bliższy komunizmowi według formuły Lenina «Sowiety plus elektryfikacja»".

${ }^{112}$ K. A. Jeleński, $O$ „Ziemi Ulro” po dwóch latach, s. 15.

${ }^{113}$ W cytowanym już tekście Czyste malarstwo czy poetyka Jeleński zauważa kolejną istotną sprzeczność na terenie sztuki współczesnej — pisze słusznie: „Malarstwo «czyste» nie istnieje, chyba jako tautologia. [...] Jednym z paradoksów awangardy ostatniego półwiecza jest, że podaje się ona nieraz za szczyt «czystego malarstwa» [...] podczas gdy tyle w niej jest elementu mózgowego»" (s. 189).

${ }^{114}$ K. A. Jeleński, Czyste malarstwo czy poetyka, s. 193. 
Można by odpowiedzieć, że „śmierć Boga” nie oznacza przerwania nici z „doświadczeniem innego wymiaru”, po prostu dlatego, że ten ,inny wymiar” istnieje w człowieku, że istnieją oczywiście zapytania, które są „odpowiedzią”; że „diabel” jest również tylko jedną z projekcji tego ,innego wymiaru” w człowieku ${ }^{115}$.

I dalej:

Sztuka dla niego [tj. Czapskiego] jest funkcją obiektywnej metafizyki o chrześcijańskim podłożu. Esencją tej metafizyki jest zgoda na harmonię świata. Stąd tak mało zainteresowania u Czapskiego dla ,prometejskiej”, buntowniczej formy sztuki. [...] nihilistyczne i „bluźniercze” formy sztuki są mu obce ${ }^{116}$.

Te „obce” Czapskiemu formy sztuki, nie są na pewno obce Jeleńskiemu i - co oczywiste - nie jest to wynikiem różnych preferencji estetycznych, lecz perspektyw światopoglądowych. W innym miejscu Jeleński cytuje Czapskiego, który pyta: „Czy można dojść do sztuki pełnej, nie idąc nigdy tą wąską ścieżką pokory absolutnej?” — to pytanie także jest dla Jeleńskiego przejawem postawy co najmniej bliskiej chrześcijaństwu. Tymczasem sztukę Czapskiego uznaje jednocześnie za satyrę współczesnej cywilizacji117, a jego poetykę malarską za „ostrą”, ,przenikliwą”, ,pozwalającą uchwycić ekscentryczne piękno zawarte w społecznym banale" - charakterystykę tę uznaje za raczej daleką od „,pokory”, stąd pojawia się u Jeleńskiego hasło konfliktu pomiędzy Czapskim-ideologiem malarstwa a Czapskim-malarzem ${ }^{118}$. Do tego rozróżnienia powróci po latach w tekście Czapski nareszcie scalony (1974), w którym przyznaje, że ciężko rzeczywiście wskazać konkretny moment zwrotny, w którym „z misjonarza malarstwa, niosącego do Polski dobrą nowinę natury przemienionej w tęczę, przekształca się on w twórcę o wizji własnej i niepowtarzalnej"119. Od razu jednak doprecyzowuje tę myśl, oddając Czapskiemu, że od zawsze miał własną wizję, długo jednak poddana była ona jego wpływom teoretycznym. Prześledzenie całej jego twórczej drogi utrudnia obserwatorowi fakt, że dorobek przedwojenny jest niestety w większości zniszczony — rzeczy późniejsze natomiast rozproszone po świecie.

Słowo-klucz, które powraca w niemal każdym tekście Jeleńskiego o sztuce Czapskiego to: wizja. Ona to bowiem, według Jeleńskiego, odpowiada za malarską klasę autora $\mathrm{Oka}$ :

U źródeł pasji malarskiej Józefa Czapskiego stoi nie „talent”, a właśnie wizja. Jego wczesne obrazy są często „niezręczne”. Opowiadał mi on, że Jan Cybis (,ręka” z Bożej łaski) powiedział mu, pół wieku temu i półżartem: „Wiesz, Józiu, twoje obrazy są tak brzydkie, że nigdy nie będa obojętne”. W innej epoce, kiedy żądano od malarza zdolności natychmiastowego przyswojenia sobie takich czy innych malarskich konwencji, ta trudność mogłaby go była zniechęcić. Na szczęście zaczął swą twórczość w okresie

115 Tamże, s. 194.

116 Tamże.

${ }^{117}$ W sprawozdaniu z wystawy Czapskiego w Galerie Bénézit w 1961 roku Jeleński pisze: „Czapski odszedł dziś daleko od paryskiego postimpresjonizmu swych rówieśników, ale zbliżył się, może mimo woli, do najżywszej polskiej tradycji twórczej — niepokojącej groteski, którą w literaturze reprezentują Witkacy, Schulz, Gombrowicz, Mrożek; K. A. Jeleński, Polscy paryżanie, [w:] CO, s. 210.

118 Jest to prawdopodobnie w gruncie rzeczy kwestia definicji pewnych pojęć (takich chociażby jak ,,pokora”), które Jeleński rozumie inaczej niż Czapski.

${ }_{119}$ K. A. Jeleński, Czapski nareszcie scalony, [w:] S, s. 155. 
zburzenia wszelkich konwencji, gdy oryginalność wizji zaczęto cenić wyżej niż zgrabność pędzla ${ }^{120}$.

W liście do Czapskiego, swojego ,jedynego polskiego przyjaciela”, z roku 1957, Jeleński wyznaje, prawdopodobnie w delikatnym uniesieniu, że jego malarstwo nie jest mu „specjalnie bliskie”. Tymczasem w tekstach o jego osobie i twórczości, systematycznie powtarza, jak wiele zawdzięcza właśnie jego „wizji” — chodzi przede wszystkim o wyrobienie tej niecodziennej zdolności rozpoznawania sztuki w otaczającym świecie. „Kobiety przechodzą ulicą, odmienne od tych, które chodziły po niej dawniej, gdyż są to Renoiry, te same Renoiry, w których kiedyś nie umieliśmy rozpoznać kobiet"121 . Być może chodzi o błyskawiczne poznanie materiału dla sztuki — być może jednak o samą sztukę tkwiącą w życiu i jedynie czekającą na wyróżnienie - i w ten sposób można interpretować cytowane słowa Prousta, na które powołuje się Jeleński. Czapski ma wielki dar widzenia, rozpoznawania znaków. Predyspozycja bezcenna.

Wizja Czapskiego jest istotna dla Jeleńskiego przede wszystkim ze względu na wierność pierwotnemu spojrzeniu, niezmąconemu żadną zbędną manierą:

Sekretem jego malarstwa jest, że nigdy nie podda swej wizji prokrustowym zabiegom stylizacji. Styl narzuca mu wizja pierwotna, maluje on swój obraz na cześć odbicia w zwierciadle szyby, czerwonej plamy sukni, sylwetki zauważonej w oknie przejeżdżającego metra. [...] To właśnie zachwycony szacunek malarza dla surowej materialnej rzeczywistości, dla pozornego banału stoi u podstaw uprzywilejowanej chwili, która godzi widza obrazu Czapskiego ze światem „takim, jakim jest”, ${ }^{\text {,22 }}$.

Widzenie świata „takiego, jaki jest”, a więc prawdziwego, a przy tym aktualnego, świata tuż obok, uchwyconego w błyskawicznym mgnieniu, to nie wszystko. U podstaw sztuki Czapskiego leży przede wszystkim zachwyt tym, co widziane. Sprawia to, że jego artystyczne spojrzenie uznaje Jeleński za bardzo aktualne, choć oczywiście jego dzieła różnią się znacznie od tych, które poddane są najnowszym trendom. Pod tym względem Czapski jest w ujęciu Jeleńskiego prekursorem takich zjawisk w sztuce jak pop-art: optyki są podobne — fascynacja całym, pełnym bogactwem miasta, jego różnorodnością, wielością form i znaczeń, pięknem ukrytym w zgiełku:

Chodzi tu rzecz prosta o co innego niż o stare krzesło i buty van Gogha, gdyż tej klasy „,brzydota” ma już od stu lat prawo wstępu do sfery „Piękna”. Nie chodzi mi również tutaj o neony, których odbicie w mokrym asfalcie może zachwycić najbardziej wybrednego i tradycyjnego estetę. Zainteresowanie Czapskiego afiszem kinowym, rurami kanalizacji, wnętrzem tramwaju, metrem paryskim, nie ma również nic wspólnego z nędzą, która wtargnęła w malarstwo Grosza, Dixa, poprzez protest społeczny. Podobnie jak u młodych przedstawicieli Pop-Artu stosunek Czapskiego do kalejdoskopu cywilizacji przemysłowej oparty jest na zwykłym zachwycie, nieraz połączonym z humo$\mathrm{rem}^{123}$.

Do tego precyzja i zdolność błyskawicznego uchwycenia wizji, a także swoista konstrukcja obrazu - wszystko to łączy Czapskiego z wciąż ,poszukującymi” prądami nowoczesnej sztuki, z naturą fotografii - oko Czapskiego działało niczym obiektyw: namiar i strzał.

\footnotetext{
${ }^{120}$ Tenże, Oko i czas, [w:] CO, s. 263.

${ }^{121}$ Tenże, Dar Józefa Czapskiego, [w:] CO, s. 358.

${ }^{122}$ Tenże, Oko i czas, s. 265.

${ }^{123}$ K. A. Jeleński, Aktualność malarstwa Józefa Czapskiego, Zeszyty Literackie $1994 \mathrm{nr} 45$,
} s. 52. 
Ucieczka przed obowiązującym trendem imponowała Jeleńskiemu — potwierdzeniem tego faktu są nie tylko słowa o Czapskim. To, co prawdziwe, a nie to, co modne, odnajdywał także w dziełach swej partnerki Leonor Fini, o której pisał:

Jeśli w epoce, w której kwitnie stylizacja, Leonor Fini posiada styl, to dlatego, że nie próbowała ,narzucić swej wizji przedmiotom”, jak to się powiada, ale zobaczyła je tak, jakby widziała je po raz pierwszy, i po to, by mogły objawić się pod jej spojrzeniem ${ }^{124}$.

Nie narzucała swej wizji, tj. nie ulegała temu spojrzeniu, które mogło być zdeterminowane przez czynniki wtórne, zewnętrzne.

Zaufanie wizji własnej, osobistej, to także istota podziwu Jeleńskiego dla twórczości wspominanego już Jana Lebensteina: „Żaden prąd, żadna moda, żaden wzgląd zewnętrzny nigdy nie zaważył na twórczości Lebensteina" ${ }^{125}$. Z malarzem Jeleński przyjaźnił się wiele lat. Jego admiracja dotyczyła jednak — co dla Jeleńskiego charakterystyczne — nie tylko dzieła, ale i samego artysty. Jeleński podziwiał Lebensteina za jego postawę, za odmowę udziału w rzeczywistości Polski Ludowej i wybór życia na obczyźnie. Zbawił on artystę ,nie tylko od kapitulacji przed Lewiatanem w okresie jego wczesnej młodości”, lecz także od pułapek szybkiego powodzenia. Jeleński po raz pierwszy zetknął się z jego dziełem poprzez reprodukcje zamieszczone w jednym z krajowych wydawnictw około roku 1955. W trzy lata później, kiedy powstała Galerie Lambert, namówił Kazimierza Romanowicza na zorganizowanie malarzowi wystawy, do której doszło w roku kolejnym i od tamtej pory przyjaźń z Lebensteinem trwała nieprzerwanie.

Czytając po raz pierwszy wiersz Zbigniewa Herberta Potęga smaku, przyszło mi na myśl, że poeta używa w nim liczby mnogiej nie tylko ze względu na zwykłą konwencję autorską, że myśli o nielicznych twórcach swego pokolenia odpornych na „heglowskie ukąszenie", którzy dosłownie nie byli w stanie dostosować się do wymogów polskiej wersji żdanowizmu i temu zawdzięczają swój spóźniony debiut dopiero w latach 1955[19]56. Jednym z nich był niedawno zmarły Leopold Tyrmand, którego tu wspominam, gdyż był w najcięższym okresie blisko z Herbertem związany. Dwóch innych podziwiałem na równi z Herbertem od chwili zetknięcia się z ich dziełem — Mirona Białoszewskiego i Jana Lebensteina ${ }^{126}$.

Fascynacja sztuką nowoczesną jest po części także przejawem szerszego zainteresowania Jeleńskiego — współczesność intrygowała go pod wieloma względami. Patrzył na nią z wielu perspektyw.

\section{Stawiać opór ale nie unicestwiać}

Wątkiem równoległym do tematu sztuki współczesnej w eseistyce Jeleńskiego są - sygnalizowane już przy okazji polemiki z Ewą Bieńkowską — rozważania o przemianach cywilizacyjnych. Jeleński był człowiekiem swojej teraźniejszości, swojej współczesności. Jego zakorzenienie w przeszłości jest oczywiste, był człowiekiem pamięci. Współczesność była natomiast dla niego czymś fascynującym, pociągającym,

\footnotetext{
${ }^{124}$ Tenże, Leonor Fini, Zeszyty Literackie 1986 nr 16, s. 77.

125 Tenże, Fragmenty o Lebensteinie, tłum. J. Lisowski, Zeszyty Literackie 1993 nr 41, s. 168.

${ }^{126}$ K. A. Jeleński, Samotna droga Jana Lebensteina, Kultura 1985 nr 7/8(454/455), s. 16 17. Szkic przygotowany z okazji 30-lecia twórczości malarza, wygłoszony na spotkaniu zorganizowanym przez oo. pallotynów w Paryżu 3 czerwca 1985.
} 
czymś w nieustannym ruchu, stąd i jego liczne wypowiedzi na temat aktualnych przemian w sztuce. Józef Czapski wspomina Jeleńskiego po latach:

Jak on nawet tego drania, co teraz umiera, Daliego, cenił... Jak Dali jechał z kapustą w aucie, jakieś takie bzdury robił, to Kot mówił: „No, no...”. [...] I tu mam właściwie pretensje do Kota, że modniś był, że to go ciągnęło, bo to było zupełnie nowe. On miał węch i też wpadał. Ale - to prawda — prędko wyskakiwał potem. Atrakcją była dlań nowość w sensie młodości właśnie ${ }^{127}$.

W swojej eseistyce Jeleński poświęcił wiele miejsca refleksjom na temat kierunków rozwoju współczesności. Bardzo istotnym zjawiskiem była dla niego kultura masowa ${ }^{128}$, którą łączył z często przez siebie używanym pojęciem społeczeństwa przemysłowego, gdyż, jak zauważał: ,związana jest ona nie z formą własności, ani systemem społecznym, ale ze stopniem rozwoju przemysłowego" ${ }^{\text {"129. W }}$. Wekście Nowe oblicze Marksa $i$ Malthusa ${ }^{130}$ z roku 1962 podkreśla szereg kwestii wyjątkowo istotnych w kontekście postrzegania tej kultury. Rzecz najważniejsza: jak ją oceniać? Jeleński nie daje jednoznacznej odpowiedzi, wysuwa, często nie bezpośrednio, argumenty pro i contra. Jasno mówi natomiast, że:

Opłakiwanie nierozłącznie związanych zjawisk, dzięki którym życie mas ludzkich w świecie uprzemysłowionym stało się wygodniejsze, barwniejsze, bardziej różnorodne, swobodniejsze, wydaje mi się formą nieznośnego purytanizmu, niedopuszczalnej pogardy dla człowieka ${ }^{131}$.

Tymczasem - jak zauważa - intelektualiści są przeważnie niechętni kulturze masowej, niewielu łączy ją z nadzieją lepszego jutra. W liście do Miłosza z roku 1964 pisał:

${ }^{127}$ J. Czapski, Świat w moich oczach, rozmowy przeprowadził P. Kłoczowski, Ząbki-Paris 2001, s. 164.

${ }^{128}$ Krąg „Kultury” okazał się środowiskiem właściwie pionierskim na tle rodzimego podjęcia tematu kultury masowej. Jego działania miały wpływ na rozpoczęcie dyskusji w kraju. Poza Jeleńskim uwagę poświęcił jej chociażby Miłosz, który, w serii „Dokumenty” Instytutu Literackiego, opracował (wybrał teksty, przetłumaczył je i poprzedził wstępem) wydaną w roku 1959 (na pięć lat przed ukazaniem się w kraju pierwszej poważnej pracy na ten temat — książki Antoniny Kłoskowskiej Kultura masowa. Krytyka i obrona, Warszawa 1964) antologię Kultura masowa - tom zawierający kilka klasycznych tekstów na temat specyfiki kultury popularnej oraz jej relacji z kulturą wyższą. W liście do Jerzego Giedroycia z roku 1962 Jeleński pisze natomiast: „Dam Panu notatkę o bardzo, wydaje mi się, ważnej dyskusji krajowej o kulturze masowej — między innymi artykuł Żółkiewskiego powołujący się na Morina i Bella - uznający konieczność wejścia w prąd kultury masowej. Ponieważ książki, na które Żółkiewski się powołuje, posłałem mu ja — a z drugiej strony w świetle akcji «Kultury» w tej dziedzinie — książka (antologia) Miłosza, artykuły moje, Miłosza, Mieroszewskiego — myślę, że jest to jeden z wypadków częściowego przynajmniej wpływu intelektualnego «Kultury» i grupy ludzi wokół «Kultury» na rozwój spraw krajowych"; J. Giedroyc, K. A. Jeleński, Listy 1950-1987, s. 353.

${ }^{129}$ K. A. Jeleński, Nowe oblicze Marksa i Malthusa, [w:] ZO II, s. 7.

${ }^{130}$ Przypomnijmy, że Thomas Malthus (1766-1834) angielski ekonomista i duchowny anglikański, jako pierwszy podkreślił znaczenie czynnika demograficznego w procesie społeczno-gospodarczego rozwoju państwa. Zauważył konkretne relacje między przyrostem ludności, a poziomem zamożności społeczeństwa. Wzrost demograficzny był według niego wielkim zagrożeniem, prowadzącym do klęski głodu i nędzy. Uznawany był za przeciwnika socjalizmu, wychodził bowiem z założenia, iż równość przyniesie jeszcze większy przyrost naturalny, a ten z kolei prowadzi bezpośrednio do wszelkich klęsk.

${ }^{131}$ K. A. Jeleński, Nowe oblicze Marksa i Malthusa, s. 7. 
Moje przekonanie, że cywilizacja przemysłowa i kultura masowa są „,dobre”, polega na tym, że nie uważam się za „humanistę” - tj. nie uważam „,człowieka” za istotę centralną i uprzywilejowaną, a mam skądinąd przekonanie, że nie można ludziom odmawiać „,dobrobytu” w przekonaniu, że istnieją jakieś formuły ludzkiego szczęścia czy „godności”,

Esej Jeleńskiego jest obiektywnym spojrzeniem na zjawisko, które dzieje się tu i teraz, wciąż jeszcze się rodzi — na tym etapie rozwoju cywilizacyjnego, zdaje się być nieodwracalne, niemal naturalne:

Kultura masowa jest spontanicznym wyrazem kierunku, w którym rozwijają się formy samego życia w każdym wysoko uprzemysłowionym społeczeństwie, bez względu na jego oficjalną ideologię. Jest to kultura ery konsumpcyjnej, stojącej u zarania i ściśle jeszcze zlokalizowanej ${ }^{133}$.

I to, co dla Jeleńskiego było tak istotne: jej immanentna zdolność do przełamywania barier różnego rodzaju — właściwość sprzyjająca, tak ważnym dla niego, tendencjom integracyjnym, burzącym mury, oddzielające różne wspólnoty. W roku 1962 pisał:

Klasowe przegrody kulturalno-obyczajowe załamują się. Załamują się podobnie przegrody pomiędzy pokoleniami. [...] Drugą cechą kultury masowej jest jej kosmopolityzm. Różnice kulturalne pomiędzy narodami nikną w miarę formowania się nowej kultury wielkiego obszaru wysoko uprzemysłowionego, który niedługo obejmie cały pas kuli ziemskiej na linii San Francisco-Nowy Jork-Paryż-Berlin-Moskwa-Tokio. Kultura masowa wytwarza nową formę synkretycznego folkloru, którego elementami składowymi są jazz, brazylijskie samby, hiszpańskie flamenco, argentyńskie tango, neapolitańska piosenka. Ale, synkretyzując ten folklor, kultura masowa nie pozbawia go elementu archaicznego. [...] jest wreszcie pierwszą kulturą czysto estetyczną, całkowicie świecką. Nie znaczy to, aby nie wytwarzała specyficznej mitologii, ale celem jej jest indywidualne, natychmiastowe użycie: nie ma w niej związku z wartościami ,transcendentalnymi", 134 .

Jeleński nie był oczywiście naiwny, jego akceptacji towarzyszy świadomość zagrożeń, jakie niesie ze sobą kultura masowa. Swoje obserwacje w cytowanym tekście opiera na jednoczesnej lekturze dwóch pozycji: L’Esprit du Temps Edgara Morina przynoszącej według Jeleńskiego nowe oblicze Marksa - i Sauver la Guerre Gastona Bouthoula, stanowiącej o nowym obliczu Malthusa. U Morina zauważa rzecz wartą podkreślenia, uświadamiającą drugi aspekt wspomnianego estetycznego charakteru tej kultury:

Morin zwraca uwagę na dwa bieguny tej cechy czysto estetycznej. $\mathrm{Z}$ jednej strony powołuje się on na ,świadomość ironiczną”, o której Hegel pisał, że „gubi w niej to, co jest najwyższego, cieszy się samym sobą". Z drugiej strony, stosunek estetyczny nawraca do stosunku archaicznego ze światem, do dzieciństwa ludzkości, odkrywającej, pod magicznym rytuałem, grę, taniec, śpiew, poezję ${ }^{135}$.

Kulturę masową Jeleński nazywa „kulturą wczasów”. Nie ma ona jednak dla niego zabarwienia jednoznacznie negatywnego, jak dla „humanistycznych moralistów”, którzy według Jeleńskiego, pojęcie współczesnej rozrywki kojarzą jedynie z biernością, materializmem czy eskapizmem. „Nie widzą, że po raz pierwszy ludzkość w swej ma-

\footnotetext{
${ }^{132}$ Tenże, Z listów do Czesława Miłosza, Zeszyty Literackie 2001 nr 75, s. 71.

${ }^{133}$ K. A. Jeleński, Nowe oblicze Marksa..., s. 8.

${ }^{134}$ Tamże, s. 9.

${ }^{135}$ Tamże.
} 
sie zaczyna stykać się z dziedziną wolności i osobistego losu"136. Rodzi ponadto cenny paradoks: otóż kultura ta, wiążąc się z indywidualnym poszukiwaniem szczęścia, mobilizuje ludzi do wspólnego, globalnego udziału w teraźniejszości. Ma wiele oczywistych wad, jest jednak pozbawiona hipokryzji. Jeleński, trzymając w domyśle cały czas tezy Malthusa, zaznacza to, co dla jednych jest jej cechą niewybaczalną, a innym przynosi ulgę:

[...] kultura masowa jest potencjalnie kulturą regulacji urodzin, kulturą maltuzjańską. Świat kultury masowej jest przesycony erotyzmem naskórkowym i uogólnionym, który niewątpliwie rozprasza koncentrację seksualną. ,Każdy postęp erotyzmu — pisze Morin - pociąga za sobą osłabienie różnic seksualnych i współczesny rozwój homoseksualizmu jest jednym zaledwie z aspektów tego osłabienia”. Sama koncepcja życia, którą przejawia kultura masowa oparta jest na indywidualnym i prywatnym szczęściu, osiąganym w intensywnie odczutej chwili obecnej. To szczęście dotyczy nie rodziny, a pary kochanków. Współczesna cywilizacja rozwija hedonizm teraźniejszości, złożony z dobrobytu, wygody, konsumpcji, przeczący tradycyjnym koncepcjom ludzkiej egzystencji, w których człowiek poświęcał swoją teraźniejszość dla przechowania wartości przeszłości (swoich rodziców) i dla inwestycji na rzecz przyszłości (swoich dzieci) ${ }^{137}$.

Co mówią nam te słowa o samym Jeleńskim? Rzecz może oczywista, ale warta wyróżnienia: świadczą one o jego zainteresowaniu tematem i zaangażowaniu w jego podejmowanie. Niektórzy woleliby w ogóle go nie poruszać, nie wierząc, że może być godzien poważnej diagnozy. Jeleński tymczasem, w tak krótkiej formie, pod pretekstem dwóch lektur, potrafił dokonać jakże ważnego, odznaczającego się w wielu miejscach profetyzmem, rozpoznania.

To, co już być może zostało w sposób pośredni wyrażone, a co także znamienne dla Jeleńskiego, to częsta praktyka obrony pewnych zjawisk, apelu o należytą refleksję nad nimi. Stosował ją także w przypadku krytyki kultury masowej — krytyki, którą stale śledził i której mechanizmy działania lubił komentować. W eseju $O$ „kulturze masowej" inaczej (1961) stwierdza:

Wszystko to skłania mnie do podejrzenia, że krytyka „społeczeństwa masowego" i „,kultury masowej” wynika nie tylko z przesłanek intelektualnych, ale stanowi racjonalizację pewnych stanów psychologiczno-emocjonalnych. Czy nie wchodzi tu w grę słownictwo? Bez wątpienia ci, którzy mówią nam o „atomizacji”, „wykorzenieniu”, „,anonimowości”, „wulgaryzacji” wywołują w nas uczucie niepokoju, gdyż pojęcia te odpowiadają istotnie pewnym współczesnym zjawiskom. Ale wystarczy zastąpić ,atomizację" przez ,indywidualizacje”,, ,wykorzenienie” przez ,wyzwolenie z atawistycznych więzów”, „wulgaryzację” przez „,rozszerzenie dostępu do kultury”, ,anonimowość” przez „wolność życia prywatnego” - a otrzymujemy bardzo różny obraz naszej epoki $^{138}$.

W takich cytatach kryje się po trosze charakterystyczna dla Jeleńskiego przekora. Nie był on przecież orędownikiem tej kultury, mówił obiektywnie o jej wadach i zaletach. Czuwał jednak nad uczciwością w dyskursach krytycznych, był bardzo czuły na punkcie nieupoważnionych, a przez to kłamliwych uogólnień czy mylnej, bądź tendencyjnej, dwuznacznej terminologii. Lubił bronić słabszego, jego prawa do należytej, konstruktywnej krytyki. W cytowanym powyżej tekście, zestawia dwa podejścia do kultury współczesnej, a w jego porównaniu jasno widać, jak wielką uwagę przykłada do języ-

\footnotetext{
${ }^{136}$ Tamże.

${ }^{137}$ Tamże, s. 13.

${ }^{138}$ K. A. Jeleński, $O$, kulturze masowej” inaczej, [w:] ZO II, s. 43.
} 
ka, mając głęboką świadomość tego, że może być on przecież - co często wykorzystują krytycy — tendencyjnie wartościujący. Konfrontacja pojęciowa, o której wspomina, znalazła swój wyraz w dwóch tekstach: Jeana Duvignauda, Pour entrer dans le vingtième siècle (Paris 1960) i Elémire Zolli, Eclissi dell'intellettuale (Milano 1959): Francuza i Włocha, którzy niezależnie napisali — pozornie — tę samą książkę. Obaj poświęcają działy literaturze i jej związkom $\mathrm{z}$ aktualnymi wówczas przeobrażeniami przemysłowymi: dla Duvignauda literaturę tej cywilizacji określa zmysł „ryzyka”, rozumianego jako ,symbolu woli w starciu ze światem rzeczywistym, przejściem nad

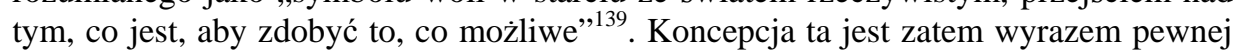
nadziei, ufności w epokę i jej możliwości. Zolla z kolei w swej książce kojarzy literaturę tego czasu z pojęciem ,gracza” — niewolnika hazardu, którego „czyny zależne są od maszyny i od masy i jego margines wolności ograniczony jest do przypadku"140. Jeleński uważa to za przejaw nienawiści (choć nienawiści niezakłamanej, nieodrzucającej społeczeństwa przemysłowego) Zolli do swojej epoki. Stanowisko i odczucie Włocha jest zgoła odmienne od stosunku Duvignauda. Obaj posługują się różnymi — w jakiś sposób wartościującymi — terminami: Duvignaud mówi o „społeczeństwie masowym”, podczas gdy Zolla preferuje pojęcie „,człowieka masy”. Ich wizje, oparte przecież na tych samych danych, rozmijają się. Dla Jeleńskiego bardziej prawdopodobne wydają się konkluzje Francuza, ma jednak świadomość, że celem Zolli mogła być krytyka nie tyle całej epoki, co jedynie ,pewnego typu współczesnego włoskiego drobnomieszczanina"141. Znając dobrze Włochy i osobiście doświadczając ,gorączkowego ogłupienia milionów”, przyznaje mu, że jego wnioski są bardzo kuszące. Ale zna też Jeleński przecież efekty rozwoju kultury masowej w innych krajach i widzi w niej wielkie szanse dla ludzi spoza elit:

\begin{abstract}
Anglia [...] Kiedy tam przyjechałem po raz pierwszy był to kraj, w którym mimo ogólnie wysokiego poziomu życia, wszystko, co jest radością, przyjemnością, urozmaiceniem, zabawą, kolorem, wydawało się wyłącznie zarezerwowane na użytek ,klas wyższych”. Mimo wygodnych domów z łazienkami, mimo wysokich płac, robotnicy angielscy mieli na sobie piętno szarzyzny, nudy i smutku, czas wolny spędzali w koszmarnych pubach, mówili „Sir” do każdego idioty o „,dobrym” akcencie. Dzisiaj każde miasteczko angielskie ma popularne dansingi, wesołe kawiarnie i Espresso-bars, młodzież robotnicza ubiera się kolorowo i z dużym smakiem, dziewczyny często na modłę amerykańską, chłopcy ze skłonnością do anachronicznej ekscentryczności. Nic dziwnego, że są weselsi, przystojniejsi, że przestali szanować „gentlemana”, że czują się wreszcie w swym kraju wszędzie u siebie: rewolucja dokonana przez kulturę masową w codziennym sposobie bycia nadała wreszcie prawdziwą zawartość dawniejszym reformom społecznym ${ }^{142}$.
\end{abstract}

Obaj autorzy przyznają, że włączenie literatury (sztuki) w nowoczesny system komunikacji służy jedynie utworom o wątpliwej wartości artystycznej. Nie zmienia to jednak faktu, że równocześnie rośnie także rozgłos wielkich pisarzy, których nazwiska porywane są przez nowe techniki popularyzacji. Zolla obawia się swego tytułowego „zmierzchu intelektualisty”, Duvignaud wie tymczasem, że chodzi o pewne uprzywilejowania konkretnych kręgów, które wraz z rozwojem kultury masowej zostają zagrożone. Rozwój kultury nie jest jednak według niego narażony na żadne niebezpieczeństwo, wręcz przeciwnie — większa do niej dostępność może jedynie wspomóc jej roz-

\footnotetext{
${ }^{139}$ Tamże, s. 44.

${ }^{140}$ Tamże.

${ }^{141}$ Tamże, s. 46.

142 Tamże, s. 46-47.
} 
wój. Jeleński docenia argumentację obu stron, nie jest radykalnym zwolennikiem żadnej z nich, być może jego przychylność do jednej z tych optyk wyraża ostatnie zdanie eseju, poświęcone Duvignaudowi: „Dla niego, to sam rozwój społeczny świata niesie w sobie obietnicę ożywienia u współczesnego człowieka źródeł wyobraźni, powrotu do spontaniczności i do autentyczności" ${ }^{143}$.

Istotne może okazać się w tym miejscu stanowisko Jeleńskiego, które przedstawił dekadę później, w raporcie pisanym dla Fundacji Royaumont ${ }^{144}$ na początku lat 70 ., dyskutującym związki zmian zachodzących na terenie świata nauki i kultury. Jeleński umieszcza w nim, co w jego przypadku nie było praktyką częstą, akapit mówiący wprost o jego poglądach na dorobek ,nowej” cywilizacji:

Nie wierzę $w$ bliską kontrkulturze utopię rewolucyjną, nie podzielam też jej marzeń o powrocie do natury. Podobnie jak Edgar Morin lub Jean-François Revel uważam, że do obalenia archaicznych zakazów i uzyskania pełnej wolności dla wszystkich dojść może jedynie wówczas, gdy cywilizację technologiczną potraktujemy nie jako cel sam w sobie, lecz jako środek do celu: Nie ocali nas ani jej zniszczenie, ani jej rozwijanie: musimy stawiać jej opór, ale nie unicestwiać ${ }^{145}$.

Refleksja o rozwoju cywilizacji, jej aktualnym położeniu i perspektywach była obecna w tekstach Jeleńskiego od początku. W pierwszym swoim eseju dla „Kultury”, nadesłanym jeszcze z Neapolu, zatytułowanym Apokalipsa i perspektywa (1950), zauważa, że dwa przeciwstawne sobie światopoglądy: komunizm i katolicyzm, zapowiadają wizję końca historii, której to wizji, w jakimkolwiek wydaniu — powiedzmy od razu - Jeleński nie akceptuje. Dotyczy to zarówno utopii komunizmu, którego historiozofia (w postaci materializmu historycznego) przewiduje wieczne szczęście społeczeństwa bezklasowego $^{146}$, jak i katolicyzmu, którego wizja apokalipsy paradoksalnie także przynosi zapewnienie finalnego zwycięstwa (katolików), bo — jak pisze Jeleński — każdy z nich musi wierzyć, że ostatecznie „będzie jeden pasterz i jedna owczarnia”. Czy historia ma koniec? Według Jeleńskiego

liberał i humanista nie może bez zastrzeżeń poddać się sugestii tych wizji, w których abstrakcja naukowa, ekonomiczna, czy metafizyczna wyklucza wiarę w człowieka, w jego instynktowne, wiecznie odradzające się przywiązanie do wolności. Wolny wybór i czyn, wybór pomiędzy jednym czynem a drugim — oto postawa liberała, która trzyma go wewnątrz ram własnej cywilizacji i stanowi zarazem jej obronę. I dlatego dla liberała otwarte jest tylko jedno okno na przyszłość — okno historii ${ }^{147}$.

W słowach tych pobrzmiewa echo jednej z nielicznych deklaracji, jaką złożył w życiu Jeleński - deklaracji liberała. W liście do Józefa Czapskiego, także z roku 1950, odnajdujemy fragment, uzupełniający jego wyraz wiary w człowieka:

Mój liberalizm jest zbyt głęboko zakorzeniony i jestem przekonany, że to, co jest esencją człowieczeństwa, nie może bezpowrotnie przeminąć. Niemniej myślę, że istotnie żyjemy w końcowym stadium naszej cywilizacji i że proces przemiany, który tak szybko obrót

143 Tamże, s. 50.

${ }^{144}$ W kierowanym przez swego przyjaciela, Jacques'a Monoda (francuskiego biochemika, laureata Nagrody Nobla), Centre Royaumont pour une Science de l'Homme, Jeleński pełnił w latach 1972-1976 funkcję dyrektora administracyjnego.

${ }^{145}$ K. A. Jeleński, Bioantropologia a kultura wspótczesna, s. 207.

${ }^{146}$ Dla Jeleńskiego utopia, złoty wiek, ,zakończenie z bajki dla dzieci” to już nie historia ta bowiem nie może posiadać perspektywy „zakończenia”, w jakiejkolwiek postaci.

${ }^{147}$ K. A. Jeleński, Apokalipsa i perspektywa, [w:] ZO II, s. 133. 
przyjął w ciągu naszego życia, dotyczy nie tylko zagadnień ekonomicznych, ale również samej esencji ludzkich pojęć i stosunku człowieka do człowieka. Przemiany takiej, że w przyszłości słowa, jak miłość, praca, chleb, przyjaciel będą miały inne znaczenie: skojarzenia historyczne czy religijne, które w naszej podświadomości indywidualnej wywołują obrazy z Biblii, z greckich mitów, z średniowiecznej poezji, z renesansowych dzieł sztuki, utracą rację bytu, a na ich miejsce narosną nowe nawarstwienia. Wierzę, że ta zmiana, która zacznie się okresem ciemnym i w którym dla nas nie będzie miejsca, zakończy się jakimś nowym renesansem ,liberalizmu” — chyba w idealnej anarchistycznej formie ${ }^{148}$.

Nie utopia i nie apokalipsa - ciągłość, mówi Jeleński, cykliczność. Być może obecna cywilizacja jest rzeczywiście w momencie kryzysu, grozi jej rychły upadek, ale może to oznaczać jedynie zmianę, przynoszącą kolejny etap historii, w żadnym wypadku jej koniec. Historia nie ma końca. Na taką wizję nie pozwala Jeleńskiemu prawdziwa wiara w człowieka — swój esej kończy zdaniem:

A jednak, chociaż bolesna wydaje się nam myśl, że nasza cywilizacja może nie być wieczna i że na jej miejsce przyjdzie może nowa, poczęta nie nad Morzem Śródziemnym lecz na Missisipi czy na stokach Uralu, obraz Eneasza, który z płonącej Troi wynosi starego ojca bardziej jest zgodny z wiarą w wartość i wagę człowieka niż obraz bram z napisem: Lasciate ogni speranza... ${ }^{149}$.

Pointa ta jest bez wątpienia znaczącym świadectwem światopoglądu Jeleńskiego — jest także okazją do wspomnienia o jego stosunku do kwestii wiary i religii.

\section{Metafizyka ateisty}

Jeleński był ateistą, nigdy tego nie ukrywał - mogłoby się zdawać, że wręcz przeciwnie. Po latach przyznawał, że wiara była tym darem, którego nie zaznał, a który wart jest pozazdroszczenia. Wojciech Karpiński wspomina: „Kot podkreślał swój ateizm, ale pisał z przejęciem o Acedii, o grzechu przeciw Duchowi Świętemu, grzechu zobojętnienia, bał się wysysającego wiru nicości" ${ }^{150}$. Gustaw Herling-Grudziński notował w Dzienniku pisanym nocą:

Kot zawsze słuchał lekko nastroszony wywodów trącących «transcendencją», robił wyjątek (za przykładem Jana Potockiego) tylko dla cudów, ,jedynego dowodu na istnienie Boga”. Nastroszony, tak, lecz równocześnie z wyrazem pragnienia w oczach ${ }^{151}$.

\section{Krzysztof Jeżewski wspomina z kolei:}

To prawda, że jego głęboki racjonalizm kazał mu wystrzegać się zarówno utopii komunizmu jak i transcendencji religii. Jednakże, bez względu na to, jak by przebiegała jego ewolucja światopoglądowa (przypomnijmy przypadek Jastruna, Kijowskiego, Kamieńskiej, Wirpszy, a we Francji nawet Malraux i Sartre’a - ten ostatni, według świadectwa Jeana Guittona, w jednym z ostatnich wywiadów przed śmiercią, ukrytym przez Simone de Beauvoir, przyznał się do całkowitej porażki i oświadczył, że wierzy w Boga), Jeleński, podkreślmy to raz jeszcze, należał do tych agnostyków, z którymi chrześcijanie najłatwiej znajdują wspólny język ${ }^{152}$.

${ }^{148}$ Tenże, Listy z Korsyki..., s. 7.

${ }^{149}$ Tenże, Apokalipsa i perspektywa, s. 136.

${ }^{150}$ W. Karpiński, Uśmiech Kota, Zeszyty Literackie 1988 nr 21, s. 71.

${ }^{151}$ G. Herling-Grudziński, Dziennik pisany noca 1984-1988, cz. II, Warszawa 1990, s. 103.

${ }^{152}$ K. Jeżewski, Wspomnienie w dziesiąta rocznice śmierci. Konstanty Jeleński, Archiwum Emigracji. Studia - Szkice - Dokumenty 1999 z. 2, s. 220. 
Racjonalizm liberała. Ale trzeba także dodać, że od religii odstraszał Jeleńskiego często związany z nią radykalizm, oznaczający brak tolerancji, o którą stale walczył. Ten argument był dla niego wystarczający, aby opowiadać się zdecydowanie przeciwko narodowo-katolickiej wizji Polski, przeciw narodowcom, „którzy chcieli przywłaszczyć sobie całą kulturę polską i idealizować naszą historię" ${ }^{253}$. Cenił jednak bardzo ludzi „zdrowej” religii, w swej religijności konsekwentnych i żywo myślących. Przykładem takiej postawy był dla niego Auberon Herbert, poznany w szeregach wojska polskiego w Anglii, przyjaciel „Kultury”, wyjątkowo uczulony na sprawy krajów pozostających pod sowieckim zaborem. W eseju poświęconym jego pamięci, Jeleński przywołuje wypowiedzi ludzi, którzy - w przeciwieństwie do niego samego - mieli dostęp do religijnego wymiaru życia Herberta. Podobnie jak Jeleński, który zawsze trzeźwo przyglądał się szeroko rozumianej sferze sacrum, Herbert był przeciwnikiem zmian posoborowych, stąd - znane w gronie przyjaciół - jego poszukiwania nienaruszonego obrządku łacińskiego w Kościele. Odnalazł go w kaplicy białoruskiej. „Swym katolickim przyjaciołom wręczał wybite przez siebie monety z napisem «Oddajcie nam naszą mszę», z poleceniem, by je składali na tacy w czasie kolekty"154. Takie podejście Jeleński bardzo cenił.

Sam zdawał sobie doskonale sprawę z faktu, że wybór któregoś z religijnych paradygmatów nierzadko ułatwia rozwiązywanie rozterek natury egzystencjalnej, daje konkretne, gotowe odpowiedzi. Ale takim odpowiedziom nie chciał zaufać. Chciał odnaleźć siebie po swojemu, podążać za własną obserwacją i wyobraźnią.

Zaufanie burzył zapewne także udział ludzi Kościoła w bieżących sprawach kraju, działalność PAX-u, ale nie tylko. W liście do Giedroycia z roku 1957 odnajdujemy fragment:

Charakterystyczna jest mowa Wyszyńskiego w Częstochowie (znam ją tylko z „Monde'u”), która wydała mi się naprawdę bezczelna: ta negacja moralności socjalistycznej - zrozumianej w ogóle jako moralność świecka — to przypisywanie katolikom zasługi za akcję prowadzoną przez robotników, komunistów i lewicę inteligencji, ta obrona „księży patriotów” (że są lepsi, ,bo Polacy-katolicy”, od katolickich ,,progresistów" na Zachodzie — tak jakby nie było zasadniczej różnicy — parszywego oportunizmu tych księży w Polsce i mylnego, ale odważnego punktu widzenia katolików sympatyzujących z komunizmem po tej stronie!) ${ }^{155}$.

Ale nie tylko katolicyzm w wydaniu polskim nie odpowiadał Jeleńskiemu, rozliczne „nieporozumienia” odnajdywał na terenie całej Europie. Raziła go swoista „elastyczność" katolicyzmu, drażnił brak konsekwencji. Katolików często postrzegał jako przyjmujących postawę przesadnie defensywną, czasem konformistyczną. W roku 1957 pisal:

[...] katolicyzm na najwyższym poziomie ma zadziwiający dar mimikry każdej najnowszej pozycji myślowej. Przy każdym zagrożeniu Kościół wysyła żywe torpedy, piątą kolumnę, której zadaniem jest zbadanie i próba opanowania wrogiego terytorium. Gdyby Kościół był zgodny z wyobrażeniem, jakie ma o nim mały masoński czy marksistowski Jasio, można by przypuścić, że są jakieś odprawy w Watykanie czy u generała jezuitów. Egzystencjalizm? Wysyłamy Gabriela Marcela i Enrica Castellego. Wsparcie flanków przez dominikanów niemieckich. Marksizm? — Zakładamy „Esprit”, wysyłamy Domenacha, wsparcie flanków przez księży-robotników i dominikanów francu-

\footnotetext{
${ }^{153}$ Zob.: K. A. Jeleński, O Gombrowiczu, s. 462.

${ }^{154}$ Tenże, Pamięci Auberona, [w:] CO, s. 100.

155 J. Giedroyc, K. A. Jeleński, Listy 1950-1987, s. 237.
} 
skich. Do czego katolicyzm nie jest zdolny! Przecież przyswoił sobie nawet ateizm w dziełach ojca Teilharda de Chardin! ${ }^{156}$

Wszystko to oddalało Jeleńskiego od tradycyjnie rozumianej religijności. Ale zawsze pociągała go tajemnica - coś, czego myśl nie przenika, a co niekoniecznie przynależy do sfery sakralnej.

Otóż interesują mnie przede wszystkim wartości irracjonalne — powiedzmy to, co jest dziedziną religii, a co w formie namiastki zostało przejęte przez poezję (w sensie najszerszym twórczości indywidualnej). Jestem, z drugiej strony, zwolennikiem (nie tak jak się jest „Zwolennikiem demokracji” czy ,,amatorem pączków”) jakiegoś społeczeństwa zbliżonego do wolności, a więc racjonalnego. [...] Myślę po prostu, że ludzie nie stworzyli jeszcze społeczeństwa wyzwolonego ze zdesakralizowanych wartości, w którym mogliby się jakoś rozprężyć ${ }^{157}$.

Jeleński wątpi w możliwość powstania takiego społeczeństwa. Zastanawia go jednak, czy byłoby ono w stanie, jako racjonalne, wypracować lub umożliwić rozwój wartości, które tradycyjnie należą do dziedziny religii. „Jak można wierzyć w cuda, nie wierząc w Boga" - tak sam skrótowo i z przymrużeniem oka opisał swoją myśl w liście do Czapskiego z $1973^{158}$ — te cuda, bez Boskiej pieczęci, w społeczeństwie racjonalnym, byłyby chyba jego ideałem: „niezdolny od dziecka do «wiary w Boga», odczuwałem zawsze potrzebę «wiary w cuda», i cieszy mnie każda ich afirmacja, która się nie ucieka do żadnego deux ex machina" ${ }^{\text {"159. }}$.

W światopoglądzie Jeleńskiego katolicyzm kojarzony był negatywnie najprawdopodobniej także ze względu na szereg haniebnych działań, jakimi zapisała się w polskiej historii reprezentacja radykalnej prawicy. Lansowany przez nią wzór Polaka-katolika był dla niego całkowicie sprzeczny z tradycjami polskimi, rodzimą kulturą, która stała się przecież istotną częścią dorobku światowego. Niechęć do prawicy nacjonalistycznej wynikała u niego z powodów elementarnych — zdaje się, że zdecydowanie bardziej uczuciowych niż politycznych. Ten określony typ „,polskości” nazywał „drobnomieszczańskim wcieleniem wiecznego faryzeusza”. Tak jak Miłosza, irytowały go ,pobożne pienia na pokładzie okrętu, we wnętrzu którego przewozi się niewolników”. Istotna była także dla niego kwestia żydowska. Jako filosemita nie raz w swej eseistyce podejmował problem polskiego antysemityzmu.

W eseju Hańba czy wstyd (1968) Jeleński zauważa pewną nieprawidłowość w postrzeganiu tego problemu, o którym — jeżeli w ogóle — mówi się w sposób metodycznie niepoprawny. W tekście przywołuje wystąpienie Pawła Jasienicy z walnego zebrania oddziału warszawskiego Związku Literatów Polskich, na którym przeczytał on jedną $\mathrm{z}$ antysemickich ulotek rozdawanych na uniwersytecie, a której treść wywołała oburzenie zebranych. Powodem wątpliwości Jeleńskiego okazał się jednak komentarz Jasienicy:

Koledzy! Ktoś dla sobie wiadomych celów usiłuje ściągnąć na nasz naród piętno antysemitów. Brak tolerancji odbił się już na sprawach Polski za czasów Voltaire'a, kiedy to podnoszono sprawę naszej nietolerancji religijnej. Wiem o tym dobrze, jako historyk. Nic nam dziś nie może przynieść większej szkody, jak wytworzenie w opinii świata przekonania, że jesteśmy narodem antysemitów ${ }^{160}$.

\footnotetext{
${ }^{156}$ K. A. Jeleński, Bohaterskie niebohaterstwo Gombrowicza, s. 39.

${ }^{157}$ Tenże, Listy z Korsyki..., s. 27.

${ }^{158}$ Tamże, s. 46.

${ }^{159}$ Tenże, $O$ „Ziemi Ulro” po dwóch latach, s. 15.

${ }^{160}$ Cyt. za: tenże, Hańba czy wstyd, [w:] ZO I, s. 167.
} 
Jeleński docenia odwagę Jasienicy, wie także, że ten również potępia antysemityzm. Do jego komentarza ma jednak kilka zastrzeżeń: po pierwsze, że zakłada, jakoby w Polsce antysemityzmu nie było (co, powiedzmy uczciwie, niekoniecznie z wypowiedzi Jasienicy wynika), a po drugie, że ,chodzi o tajemniczy spisek mający na celu «skompromitowanie narodu» i że największym złem jest właśnie «kompromitacja» w oczach światowej opinii" (co ma już pełne uzasadnienie). Intencje Jasienicy zapewne nie były złe i trudno obiektywnie stwierdzić, czy problem tkwił rzeczywiście w samych założeniach, czy jedynie w dyskusyjnej, niekoniecznie trafnej formie ich przedstawienia. Radar Jeleńskiego zareagował jednak błyskawicznie, bo sprawa rzeczywiście wymagała uściślenia. Tekst pochodzi z roku 1968, wyczulenie zatem jest zrozumiałe. Zebranie ZLP jest jednak przyczynkiem do refleksji bardziej ogólnej. Jeleńskiego irytuje przede wszystkim zakłamanie i hipokryzja władz. Przywołuje wyjaśnienie Gomułki, jakoby to ,antysyjonizm nie miał nic wspólnego z antysemityzmem"161. Sytuacje ironicznie kwituje, mówiąc, że „Gomułka nie jest antysemitą. Zarzuca on po prostu Żydom, że są «syjonistami»" "162, co ostatecznie prowadzi do potrzeby redefinicji pojęcia „syjonizmu”, tak zgrabnie wplatanego przez przedstawicieli władzy do wypowiedzi publicznych. Ostatecznie okazuje się, że ów „syjonizm” Żydów polega na tym, że nie godzą się na gomułkowską tezę, jakoby to Izrael był agresorem w ostatnim (wówczas) konflikcie z Arabami, nie godzą się zatem — jak podkreśla Jeleński — na propagowanie nieprawdy.

Problem jest skomplikowany, gdyż atakujący z obu stron politycznej sceny. Z jednej strony oenerowskie „Bij Żyda”, z drugiej komunistyczne władze, mobilizujące tysiące ludzi pod hasłem antysyjonizmu, a pośrodku Kościół i liberalna opozycja w ,zmowie milczenia”. Czy rzeczywiście polskiego antysemityzmu nie ma? — pyta Jeleński $^{163}$. Czy to jedynie szerzona przez Żydów propaganda? Czy tylko prowokacja? — jak chciał być może Jasienica. Chóralne „Hańba!”, które padło po jego przemówieniu, to dla Jeleńskiego za mało.

W liście do Jarosława Iwaszkiewicza z roku 1957 pisał:

Wybieram się na parę dni do Rzymu zobaczyć Ciocię Magdzię Skarżyńską — postaram się zobaczyć Wyszyńskiego — jeśli będzie chciał mnie przyjąć, żeby błagać go o akcję żywszą (w ogóle jakąś) w sprawie antysemityzmu. Jedyna dziedzina, w której Kościół może się na coś zdać, a tu ani mru-mru. Nie masz pojęcia jaki mam wstręt do tego antysemickiego harcerstwa, jakim jest polski katolicyzm ${ }^{164}$.

Wątek antysemityzmu pojawia się także w eseju Antoni Stonimski i jego ojczyzna ${ }^{165}$, napisanym po śmierci poety. Jeleński, przytaczając słowa dość wybiórczego nekrologu Słonimskiego z „Tygodnika Powszechnego”, przypomina przedwojenny status poety znienawidzonego ,przez ruch utożsamiający się [...] z «Narodem» i przez olbrzymią

\footnotetext{
161 Tamże, s. 168.

162 Tamże.

${ }^{163}$ Problem ten odnajdujemy także we wcześniejszym tekście Jeleńskiego z czasów odwilży Od endeków do stalinistów, w którym dziwi się, jak to możliwe, że od dziesięciu lat nie mówi się o antysemityzmie w Polsce i unika tematu jakby go nie było. Według niego antysemityzm jest: w sposób zadziwiający przetrwał okupację, a masowe mordy nie spowodowały społecznej solidaryzacji po wojnie. Okazało się także, że nie tylko endecy są antysemitami — jest to zjawisko obecne także w szeregach partyjnych stalinistów, którzy po odwilży, szukając nowego elektoratu, mobilizują ciemny lud pod hasłem antysemityzmu; zob.: Kultura $1956 \mathrm{nr}$ 9(107), s. 13-20.

${ }^{164}$ J. Iwaszkiewicz, T. Jeleńska, K. A. Jeleński, Korespondencja, s. 54-55.

${ }^{165}$ K. A. Jeleński, Antoni Stonimski i jego ojczyzna, Kultura 1976 nr 10(349), s. 123-128.
} 
większość katolickiego kleru i katolickiej opinii"166. Słonimski, pobity swego czasu przez oenerowskich bojówkarzy, powrócił do Polski z wojennej emigracji — zdaniem Jeleńskiego - z pobudek czysto patriotycznych. Warto przytoczyć, cytowany przez Jeleńskiego, fragment wiersza Do przyjaciót z Anglii (którzy przed wojną namawiali poetę na wyjazd z kraju):

$$
\begin{aligned}
& \text { W mieście moim rodzinnym czasami jak złodziej } \\
& \text { Pod ścianą biegnę chyłkiem, ścigany kamieniem. } \\
& \text { Dlaczego nie przyjeżdżam i nie mieszkam z wami? } \\
& \text { Smutna to historia. Osądźcie ją sami. } \\
& \text { Może Niemiec porzucić swój kraj, jeśli woli } \\
& \text { Może nim gardzić, bo go nie widział w niewoli. } \\
& \text { Ale jak nam uciekać, nam którzy wolności } \\
& \text { Kraju swojego długo czekali w młodości, } \\
& \text { Nam, którzy z dawnych Polaków cierpieniem } \\
& \text { Jedną żyli rozpaczą i jednym marzeniem }{ }^{167} \text {. }
\end{aligned}
$$

Do kraju Słonimski powrócił w roku 1951. O swoich najgorszych decyzjach z okresu stalinowskiego pisał później bardzo ostro (i tu także trafnie wychwycony przez Jeleńskiego cytat):

$$
\begin{aligned}
& \text { Że byłem kiedyś małoduszny } \\
& \text { Że kiedyś brakło mi odwagi } \\
& \text { I że milczałem wbrew sumieniu } \\
& \text { Umierający chcę być nagi } \\
& \text { Chcę zrzucić z siebie ciężar duszny } \\
& \text { I raczej spocząć w zapomnieniu }^{168} \text {. }
\end{aligned}
$$

Fragment ten, podczas Mszy żałobnej poświęconej Słonimskiemu, cytował także ks. Jan Twardowski. Dodał jednak: „Tak pisał poeta, ale chyba nie o sobie. Niepodobna o nim zapomnieć" ${ }^{\prime 69}$.

Gdy 6 czerwca 1988 roku odbyła się msza za duszę Jeleńskiego w kościele św. Marcina, celebrujący ją ks. Pasierb podkreślał, że już od kilku lat zbliżał się on do Kościoła i żałował swojego młodzieńczego ateizmu ${ }^{170}$. Wpłynęła na to także postać Jana Pawła II, który poruszył Jeleńskiego swoją renesansową umysłowością. René Tavernier, prezes francuskiego (a potem i światowego) PEN Clubu wspominał:

Był tolerancyjnym agnostykiem, ale pewnego dnia powiedział mi: W swojej młodości nigdy bym nie przypuszczał, że pewnego dnia poczuję się tak blisko związany z polskim Kościołem ${ }^{171}$.

W liście do Miłosza z roku 1980 pisał też o księdzu Sadziku, wyznając, że „naprawdę (z daleka) go pokochał” i że jego „obecność odczuwa jako dziwne potencjalne oparcie, mimo że się zawsze «mijają»"172.

${ }_{167}^{166}$ Tamże, s. 123.

${ }^{167}$ Cyt. za: tamże, s. 127.

${ }^{168}$ Tamże, s. 128.

${ }^{169}$ Zob.: tamże..

${ }^{170}$ Zob.: J. St. Pasierb, Konstanty Jeleński - Polak i Europejczyk, Więź 1988 nr 1, s. 5153, także: J. Siedlecka, Kocik, [w:] tejże, Wypominki, Warszawa 2001, s. 172.

${ }^{171}$ Cyt. za: J. Siedlecka, Kocik, s. 172.

${ }^{172}$ Zob.: K. A. Jeleński, Z listów do Czestawa Miłosza, (1995), s. 83. 
Chyba jedyna wiara, o której można mówić w przypadku Jeleńskiego, to, towarzysząca mu całe życie, jego osobista wersja - nomen omen - teorii przypadku. W tekstach i listach stale przypomniał o roli hasard objectif w swoim życiu. Wypadki, lektury, znajomości — wszystko zdawało się podlegać tej odgórnej, nieodgadnionej regule:

Stosunek mój do Gombrowicza nie jest „obiektywny” (powiem nawet, że dzięki niemu nie bardzo w obiektywizm wierzę). Za dużo mu zawdzięczam zbiegów okoliczności, irracjonalnych przypadków, owego hasard objectif, który jest metafizyką ateisty. Podobnie z Historią. W każdym akcie sztuki jest postać mająca związek z moim życiem, i to związek, który mnie znów, jak do Rzymu, ku Gombrowiczowi prowadzi ${ }^{173}$.

Przez przypadek Jeleński poznał przecież również Ferdydurke - dzieło, które miało wyjątkowy wpływ na jego życie. Idea przypadku była także bliska samemu Gombrowiczowi:

Gombrowicz lubił te przecinające się tory fikcji i życia, lubił w ogóle (zacytuję tu kapitalną formułę Błońskiego): „Cząstki przeznaczenia uwarunkowanego sekretnie w tajnikach kosmosu”. Tak było z jego radością, kiedy szperając po genealogiach, odkrył, że ma ze mną (swoim wówczas głównym ,poplecznikiem” w Paryżu) wspólną pra-pra-prababkę ${ }^{174}$.

Dziwne prawidła hasard objectif — przypadki u Jeleńskiego na każdym kroku ${ }^{175}$. Pisząc o Ziemi Ulro zauważa:

Jak na jedną książkę sporo tu „zbiegów okoliczności”. Skorzystam z tego, że mi się nawinęły pod pióro, żeby już tu zaznaczyć, że rola rzekomych przypadków w moim życiu była ogromna od dziecka, innymi słowy, że jestem gorliwym ich tropicielem. Moi polscy koledzy z Uniwersytetu Saint Andrews pamiętają jeszcze może moje pijane rojenia na temat the Jeleński theory of coincidence, a dopiero dziesięć lat później poznałem surrealistów i ich „odkrycia” w tej dziedzinie ${ }^{176}$.

Znaczący zdaje się tu epitet „rzekome przypadki” — Jeleński wierzy w przypadek, za który musi jednak odpowiedzialna być siła wyższa - wątpliwości dotyczące tej siły, zrozumiałe w kontekście jego racjonalizmu, wynikają z braku innych jej potwierdzeń.

Mimowolne tropienie przypadków, rozpoczęte u progu dorosłości, kontynuować będzie Jeleński pod wpływem bliskich mu później teorii nadrealistów, dla których sztuka miała powstawać w wyniku działań przypadkowych ${ }^{177}$. Takim ,,przypadkowym” można by także nazwać pisarstwo Jeleńskiego: błyskawiczne wrażenia zanotowane gdzieś na marginesie, powstające w oderwaniu od ustalonej regularności — impresje od przypadku do przypadku. Nie bez powodu pierwsze książkowe wydanie swoich tekstów opatrzył tytułem Zbiegi okoliczności.

Szereg wyborów Jeleńskiego nie był jednak dziełem przypadku. Jego rzadki indyferentyzm mógł być mylący, często pozorny. Jego światopogląd, wcale nie abstrakcyjny, nie pozwalał mu na obojętność w wielu sprawach. Jego konkretne reakcje budził m.in. świat polityki i ideologii.

${ }^{173}$ Tenże, Od bosości do nagości..., s. 299.

174 Tamże, s. 300.

${ }^{175} \mathrm{O}$ ich roli wspomina Jeleński bardzo często - por. np.: K. A. Jeleński, L. Zeno, Listowna opowieść, s. 81-89; K. A. Jeleński, Listy z Korsyki..., s. 50.

${ }^{176} \mathrm{~K}$. A. Jeleński, $O$,Ziemi Ulro” po dwóch latach, s. 13.

177 O przypadku w sztuce pisał Jeleński chociażby w jednym z tekstów o Lebensteinie, w którym zaznacza, że malarz wykorzystuje ,przypadki, jakie nastręcza technika gwaszu”; zob.: K. A. Jeleński, Fragmenty o Lebensteinie, s. 168-169. 


\section{Rozumieć wszystkich}

Część tekstów Jeleńskiego dotyczy szeroko rozumianych spraw politycznych. W sposób znamienny często wykorzystywał swoje recenzje i sprawozdania z lektur do przemycania komentarzy politycznych. Nie jest jednak chyba kwestią przypadku, że edytorzy dwóch ostatnich zbiorów jego tekstów zrezygnowali z tej części eseistyki Jeleńskiego w swoich wyborach ${ }^{178}$. Być może są to teksty, w których sam Jeleński odsłania się przed czytelnikiem najsłabiej. Bada, komentuje, ale stosunkowo rzadziej niż chociażby w wypowiedziach o sztuce jest w stanie utożsamić swój punkt widzenia z czymś lub kimś. Nie zmienia to faktu, że był Jeleński bacznym obserwatorem m.in. systemu stalinowskiego, jego panowania, nie tylko w Polsce. Jego rozeznanie w kwestiach politycznych było znakomite, przenikliwie śledził przemiany społeczne. Potrafił być złośliwy, przekorny, szyderczy ${ }^{179}$, obca była mu jednak nienawiść. W tekście Notatki o żatobie z roku $1953 \mathrm{z}$ przekąsem komentuje teksty poetyckie i inne formy czci dla Stalina po jego śmierci, odnajdując w nich patos podobny do tego, który pojawiał się w notach po śmierci Piłsudskiego — ,ten sam ton «psiego» przywiązania”" ${ }^{80}$, pisze, chwaląc jedynie Gałczyńskiego, który literacko nie zawiódł. Rozczarowany jest także postawą Polaków, porównując w tekście Tryb literatury ${ }^{181} \mathrm{z}$ roku 1955 różnice w dyskusjach na zjazdach sowieckich, jugosłowiańskich i polskich pisarzy w roku 1954. Rosjanie byli w pełni świadomi swej sytuacji, dostrzegali braki w literaturze żdanowskiej, ale konsekwentnie trzymali się doktryny, mówiąc o tym bez ogródek. Polacy, w opinii Jeleńskiego, okazali się bardziej subtelni, a przez to żenujący: nie mogli wyzbyć się fałszywego wstydu tworzenia i mówienia o literaturze. Z podobnym dystansem omawia również w eseju Po „trzęsieniu ziemi”" dyskusji i artykułów po XIX Sesji Kultury i Sztuki, będących echem XX Zjazdu KPZR i referatu Chruszczowa.

Ideologii komunistycznej poświęca także tekst Bezdroża komunizmu ${ }^{183}$, przyglądając się jej kondycji tym razem po XXII Zjeździe KPZR. W roku 1966, w odczycie Wbrew utopiom $i$ apokalipsom, wygłoszonym na Konferencji „Wschód-Zachód” zorganizowanej przez Instytut Atlantycki w Rzymie, Jeleński śledzi już upadek marksizmu-leninizmu ${ }^{184}$.

Bibliografia politycznie zorientowanych artykułów Jeleńskiego jest oczywiście dłuższa. W „Kulturze” dwa z nich poświęcił Listowi 34, w jednym przyglądając się reakcjom Zachodu na jego opublikowanie, w drugim zaś opisując jego wpływ na sytuację w kraju i echa zagranicą ${ }^{185}$. Teksty $\mathrm{z}$ tego kręgu tematycznego są świadectwem zainteresowania Jeleńskiego. Być może o nim samym mówią mniej niż teksty inne -

${ }^{178}$ Mowa o wydaniach: K. A. Jeleński, Szkice (Kraków 1990) i K. A. Jeleński, Chwile oderwane (Gdańsk 2007).

${ }^{179}$ Zob. np.: [K. A. Jeleński] a. n., Emigracja à la Mike Spillane, Kultura 1956 nr 10(108), s. 89-92.

${ }^{180}$ K. A. Jeleński, Notatki o żałobie, Kultura 1953 nr 5(67), s. 10-17.

${ }^{181}$ Tenże, Tryb literatury, Kultura 1955 nr 3(89), s. 5-14.

${ }^{182}$ Kultura 1956 nr 5(103), s. 3-22.

${ }^{183}$ Kultura 1962 nr 5(175), s. 3-25.

${ }^{184}$ Tekst odczytu, pod tym samym tytułem, umieszczono w: Kultura 1967 nr 1-2(231-232), s. $123-144$.

${ }^{185}$ Zob.: K. A. Jeleński, Protest 34 w perspektywie międzynarodowej, Kultura $1964 \mathrm{nr}$ 6(200), s. 41-56; tenże, Konsekwencje protestu 34, Kultura 1964 nr 7-8(201-202), s. 196-199. 
lub po prostu inaczej, mniej bezpośrednio. Niemniej jednak natrafiamy w nich na co najmniej kilka punktów istotnych dla próby odtworzenia światopoglądu Jeleńskiego.

W pierwszej kolejności warto podkreślić cechę dla niego charakterystyczną, którą dzielił także z kilkoma najbliższymi mu ludźmi z kręgu „Kultury”. Otóż prawdą jest, o czym mówiliśmy, że Jeleński darzył wstrętem wszelkie ideologie, nie ufał ich jednostronności. W roku 1979 pisał:

[...] żywioł ideologii jest w znacznym stopniu fikcyjny i stanowi cieniutką warstwę oleju na morzu ludzkiej egzystencji. Zbyt dużo znałem lewicowych rewolucjonistów, którzy byli reakcyjnymi kochankami, zapobiegliwymi chomikami w życiu codziennym, gorliwych katolików wpatrzonych we własny pępek, nawet — choć rzadziej — tolerancyjnych faszystów, żeby wierzyć, że jakiekolwiek idee mają wiele wpływu na nasze postępowanie $^{186}$.

Wzgardy, która pojawia się w ustępach Jeleńskiego poświęconych ideologiom, nie znajdziemy jednak nigdy w jego wypowiedziach o ludziach, którym przyszło żyć w ich ucisku. We wspomnieniu o ,wyrozumiałym dla cudzych błędów, pobłażliwym i tolerancyjnym" Zygmuncie Hertzu pisał:

W przeciwieństwie do wielu innych emigrantów Zygmunt nigdy się nie oburzał na ,niebohaterskie” zachowanie takich czy innych rodaków w Kraju w najgorszym stalinowskim okresie. Miał dość wyobraźni na to, by wiedzieć, że jedynie osobiste doświadczenie - którego nam brak — mogłoby nam dać prawo do sądów ${ }^{187}$.

Podobne spojrzenie, często może nazbyt łaskawe, cechowało też Jeleńskiego. Wojciech Karpiński wspomina:

W początkach znajomości wyraźnie rozdzielaliśmy rolę, ja szarżując podkreślałem „konserwatyzm”, on przyjmował rolę „lewicowca”, czyli wyrozumiałego dla tych, którzy w okresie stalinowskim czy później zachowywali się mało godziwie. Jego tolerancja sięgała daleko, udawałem zgorszenie, ale wiedziałem, że istnieje granica tej wyrozumiałości, że on sam nie uległ nigdy heglowskim zaślepieniom ${ }^{188}$.

Jeleński był świadomy swoich łagodnych sądów. Po części z przekonań, w mniejszym stopniu być może także z pewnej przekory w stosunku do większości emigracji, bronił tych żyjących pod naciskiem reżimu, którego sam — nie będąc w Polsce od 1939 — bezpośrednio nie doświadczył. Był to kolejny przejaw jego tolerancji.

Jej wyraz odnajdujemy również w Dwóch koncepcjach szczerości z roku 1956. Tekst dotyczy artykułu Rozmowa $z$ Emigrantem Augusta Grodzickiego ${ }^{189}$, w którym autor przytacza swoją rozmowę z Jerzym Giedroyciem, skwapliwie przekręcając według Jeleńskiego - wypowiedzi Redaktora. Jeleński wyraża tu swoje rozczarowanie insynuacjami, pojawiającymi się w krajowej prasie oraz spotkaniami z częścią pisarzy z kraju - ci, według niego, chcący do niedawna utrzymywać kontakty z emigracją w dyskrecji, po odwilży udają, że to oni muszą kryć emigrantów, którzy tych spotkań się obawiają. Swoje sprostowanie do tekstu Grodzickiego kończy jednak następująco:

[...] nawet jeśli przypisywane nam będą jeszcze bardziej absurdalne wypowiedzi, zawsze jesteśmy gotowi „ochotnie" ${ }^{190}$ rozmawiać z pisarzami z Kraju. Więcej nawet: spro-

\footnotetext{
${ }^{186}$ Tenże, $O$,Ziemi Ulro” po dwóch latach, s. 23-26.

${ }^{187}$ Tenże, Zygmunt Hertz, mój przyjaciel, s. 109.

${ }^{188}$ W. Karpiński, Spotkanie z Kotem Jeleńskim, Kultura 1987 nr 7-8(478-479), s. 34.

${ }^{189}$ A. Grodzicki, Rozmowa z emigrantem, Życie Warszawy $1956 \mathrm{nr} 48$, s. 4.

${ }^{190}$ Termin Grodzickiego.
} 
stowanie to zamieszczamy dlatego, aby z góry rozprawić się z wszystkimi możliwymi fałszywymi wersjami naszych wypowiedzi. A raczej, nie tyle aby „rozprawić się” z nimi: aby je z góry wytłumaczyć jako naturalną konsekwencję dialogu, w którym każdy z partnerów dysponuje innym wymiarem wolności, szczerości i lojalności ${ }^{191}$.

Znamienną dla Jeleńskiego wyrozumiałość odnajdujemy również w słowach $D w u$ głosu o Iwaszkiewiczu, przeprowadzonego z Gustawem Herlingiem-Grudzińskim na łamach „Kultury” w roku 1980, po śmierci autora Brzeziny. Ich wspomnieniowy dialog to de facto starcie dwóch zupełnie rozbieżnych poglądów i doświadczeń. Autor Innego świata podkreśla oczywiście serwilizm Iwaszkiewicza, wypomina mu szereg incydentów z jego udziałem. Dla nas istotne są argumenty Jeleńskiego. Z Iwaszkiewiczem czuł więź niemal rodzinną ${ }^{192}$, nie ukrywał, że jego spojrzenie nie może być obiektywne przyznawał, że właściwie jest ono niemożliwe. Znając oczywiście różne epizody z powojennego życia Iwaszkiewicza, nie chciał kojarzyć go jedynie z okresem stalinizmu,

kiedy — według Jeleńskiego - nie było żadnego wyboru poza, być może, bohaterstwem, męczeństwem. W tych warunkach „kolaboracja” nie znaczy właściwie nic, gdyż wynika z tego, jak blisko się stoi ośrodka władzy, czego ta władza od jednostki oczekuje, a oczekuje oczywiście czego innego od jednostek sławnych, wybitnych, które mogą być użyteczne na scenie politycznej, a czego innego od tak zwanych szarych ludzi ${ }^{193}$.

Dlatego Jeleński przypomina postawę pisarza w okresie niemieckiej okupacji, kiedy to dom na Stawisku był jednym z nielicznych miejsc schronienia dla Żydów, także nieznajomych. Podkreśla również, że Iwaszkiewicz pozostał konsekwentny, kiedy Gomułka nalegał, aby Związek Literatów Polskich potępił „syjonistyczne spiski”. W jego współpracy z władzą widzi Jeleński wiele pozytywów. Wychodzi z założenia, że ktoś musiał spełniać rolę „,partnera” partii, aby zachować, ocalić jakiekolwiek wartości kulturalne w kraju. Gdyby nie zrobił tego Iwaszkiewicz — twierdzi Jeleński — los polskiej literatury byłyby na pewno gorszy. W poświęconym Gombrowiczowi zeszycie „L'Herne”, Jeleński, komentując opublikowaną w „Twórczości” kontrowersyjną korespondencję Iwaszkiewicza z autorem Pornografii, podobnie tłumaczy przyjaciela:

Iwaszkiewicz jest wielkim pisarzem i przyczynił się w poważny sposób do tego, że literatura polska przetrwała okres stalinizmu i czasy późniejsze. „Twórczość” zawdzięcza swą relatywną wolność tylko jemu. W zamian jednak musiał Iwaszkiewicz poddawać się wymaganiom reżimu i nie darmo Moskwa przyznała mu w tym roku Order Lenina ${ }^{194}$.

Jaka była motywacja pisarza? — w to nie wnika: ,zapewne dużo w niej było elementów próżności, pychy nawet, a także tego snobizmu, który był plagą przedwojennej Polski”" ${ }^{195}$. Ale to właśnie Iwaszkiewicz interweniował w sprawach wielu osób — przypomina Jeleński — i to on także „ochronił” „Twórczość”, którą Jeleński uznaje za jedno z najlepszych pism literackich w Europie ${ }^{196}$. Jeleński rozumiał jednak możliwą nieprzychylność wobec postawy i osoby Iwaszkiewicza. W liście do niego z roku 1956 pisał:

${ }^{191}$ [K. A. Jeleński] a. n., Dwie koncepcje szczerości, Kultura 1956 nr 4(102), s. 109.

192 Rena Jeleńska była wieloletnią znajomą Iwaszkiewiczów. Ostatni wiersz Iwaszkiewicza, Urania, dedykowany jest Jeleńskiemu.

193 K. A. Jeleński, Dwugłos o Iwaszkiewiczu z Gustawem Herlingiem-Grudzińskim, [w:] CO, s. 115.

${ }^{194}$ Tenże, De la difficulté d'etre Polonais, L'Herne 1971; cyt. za: J. Iwaszkiewicz, T. Jeleńska, K. A. Jeleński, Korespondencja, s. 196.

${ }^{195}$ G. Herling-Grudziński, K. A. Jeleński, Dwugłos o Iwaszkiewiczu,... s. 117.

196 Tamże. 
[...] nie zdziwię Cię i chyba nie urażę mówiąc $\mathrm{Ci}$, że dużo ludzi na emigracji i przyjezdnych z Polski ma przede wszystkim w oczach pewne ,żyro” moralne, które dałeś minionej epoce. Reprezentowałeś wówczas Polskę oficjalną, na zewnątrz. Przy Twojej kulturze, uroku, zachodniej „swojskości”, narzucało się wprost określenie „,polski Erenburg”. [...] Wszystko to się komplikuje zasadniczą sprawą „,sądzenia” innych ludzi. „Sądzenie” jest mi wstrętne. Jeśli mam tak silny pociąg do jakiegoś nowego społeczeństwa, to może przede wszystkim dlatego, że marzyłbym, aby ludzie mogli przestać ,,sądzić" jedni drugich. Tymczasem jednak wszyscy sądzimy, i zawsze trochę niesprawiedliwie, i Ty i ja także... Pamiętam jak przy mnie odmówiłeś podania ręki Miłoszowi ${ }^{197}$. Porównaj to stanowisko z tym, co pisze o Miłoszu w Twojej „Twórczości” Jerzy Kwiatkowski. A Twój wizerunek Crocego „strasznego mieszczanina”? Dziwi mnie wreszcie Twoja faculté d'indignation. [...] z chwilą pewnego ,zaangażowania” i jego oczywistych niebezpieczeństw, obelgi stają się chlebem powszednim ${ }^{198}$.

Przyjaźń z Iwaszkiewiczem nie była przyjaźnią bezkonfliktową, choć różnice poglądów nie miały tu tak daleko idących konsekwencji, jak to było chociażby — o czym za chwilę - w przypadku sporów z Giedroyciem. Po pierwszym powojennym spotkaniu z Iwaszkiewiczem w Rzymie w roku 1951, kiedy obaj faktycznie się poznali, Jeleński pisał do Redaktora:

Był tu przez tydzień Iwaszkiewicz, którego spotkałem w loży Rubinsteinów na koncercie Artura. Jadłem z nim dwa razy kolację i rozmawialiśmy zupełnie szczerze. To nieszczęśliwy, zgorzkniały człowiek, skończony jako pisarz i zdający sobie z tego sprawę ${ }^{199}$.

Giedroyc i najbliższy mu w „Kulturze” Mieroszewski mieli dość wyraźnie wyrobiony pogląd na sytuację autora Sławy $i$ chwały. W liście do Gombrowicza z roku 1956 pierwszy z nich pisat:

Iwaszkiewicz był polskim Erenburgiem i dziś ratuje swoją sytuację za wszelką cenę.

Pan ma być jego legitymacją „w nowym etapie”. Analogiczną grę prowadzi z innymi,

jak np. z Kotem Jeleńskim ${ }^{200}$.

Mieroszewski był bardziej surowy. Na łamach „Kultury” pisał:

${ }^{197}$ O tym spotkaniu z Iwaszkiewiczem Miłosz pisze: „W latach pięćdziesiątych spotkaliśmy się w Paryżu podczas antraktu jakiejś polskiej sztuki. Wiedział, że otaczają go czujne oczy szpiclów, więc rzucił szybko, przechodząc: «Z Tobą, złotko, nie mogę się przywitać»”; Cz. Miłosz, Korespondencja z Jarostawem Iwaszkiewiczem, [w:] tegoż, Zaraz po wojnie. Korespondencja z pisarzami 1945-1950, Kraków 1998, s. 123.

${ }_{198}$ J. Iwaszkiewicz, T. Jeleńska, K. A. Jeleński, Korespondencja, s. 25-26.

199 J. Giedroyc, K. A. Jeleński, Listy..., s. 84. Spotkanie to odnotował w Dzienniku także Iwaszkiewicz pod datą 14 listopada 1951: „Na rogu malutkiej uliczki dei Barbieri i placu Argentina słyszę za sobą głos: «przepraszam, pan Iwaszkiewicz?». Oglądam się i widzę tego młodego człowieka, który się przystawiał do Ewy Rubinstein. Okazuje się, że to jest młody Konstanty Jeleński, syn pani Reny Jeleńskiej, dawnej, odwiecznej naszej znajomej. Widywałem jego, ale jak miał dwanaście-trzynaście lat. Wtedy był bardzo piękny. Teraz ma koło trzydziestki, trochę łysieje, ale bardzo podobny do matki, która była w swoim czasie przepiękną kobietą. Rozmowa z Konstantym od razu zaczyna się tak jakbyśmy się znali z pięćdziesiąt lat. Idziemy gdzieś do malutkiej restauracyjki na kolację i zaczynamy gadać, jakbyśmy byli starymi przyjaciółmi i spotkali się po dziesięciu latach niewidzenia. Jeleński jest bardzo inteligentny i wykształcony, w Polsce nie był od 1939 roku, zdaje się, ale mówi po polsku bardzo dobrze. Takich młodych ludzi jak on już w Polsce nie ma: kultura, wykształcenie, duża inteligencja, a przy tym wiele wdzięku. Przypomina mi trochę Karola Szymanowskiego"; J. Iwaszkiewicz, Dzienniki; t. I: 1911-1955, oprac. A. i P. Papiescy, Warszawa 2007, s. 324.

${ }^{200}$ J. Giedroyc, W. Gombrowicz, Listy..., s. 192. 
Współdziałanie z reżymem takich panów jak Słonimski czy Iwaszkiewicz porównane być może wyłącznie do roli odegranej przez tych nielicznych Żydów, którzy kolaborowali z gestapo. Słonimscy i Iwaszkiewicze pracują nad tym, by już nigdy w Polsce nie było ani Słonimskich, ani Iwaszkiewiczów. To jest filozofia tych Żydów, którzy pomagali palić w krematoriach innych Żydów w nadziei, że w ten sposób uratują się przed zagładą $^{201}$.

Optyka Jeleńskiego była zupełnie inna, choć w korespondencji z Iwaszkiewiczem stale pojawiają się obustronne wzmianki o rozczarowaniu sądami adresata. W 1957 Jeleński pisze:

Zmartwił mnie i bardzo zdziwił Twój atak na artykuł Miłosza w „Preuves”. Zmartwił głównie dlatego, że widzę, jak bardzo się różnimy w sądach i nie mogę wprost zrozumieć dlaczego ${ }^{202}$.

Różnice utrzymywały się stale przez lata. W 1967 Iwaszkiewicz pisze: „Strasznie dużo

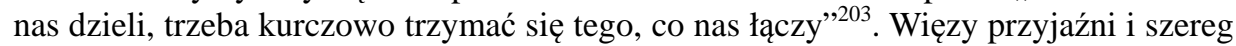
cech wspólnych szczęśliwie dominowały nad rozbieżnością poglądów. Stąd wielka czułość Jeleńskiego i zrozumienie dla Iwaszkiewicza, które dla wielu były niezrozumiałe.

Kot kierował się sympatiami osobistymi oraz oceną kogoś jako artysty czy jako pisarza, a mało interesowała go postawa polityczna czy moralna. Weźmy choćby jego adorację Iwaszkiewicza. Był w niej nie tylko podziw dla pisarza czy poety. Była w niej również słabość do człowieka. Kot miał wyraźnie dla Iwaszkiewicza taryfę ulgową. Bronił nawet jakiegoś jego oburzającego opowiadania socrealistycznego. Ja widziałem Iwaszkiewicza podwójnie: jako człowieka i działacza, którego potępiałem, i jako pisarza, autora wielu wartościowych utworów, które na pewno wytrzymają próbę czasu. Kot nie wprowadzał takiego rozróżnienia ${ }^{204}$.

Twórczość Iwaszkiewicza była Jeleńskiemu wyjątkowo bliska - odnajdywał w niej własne wspomnienia, była dla niego ewokacją świata znanego, ale już niemal zapomnianego. Z tych wspólnych, rozsypanych reminiscencji Iwaszkiewicz budował pełne obrazy:

[...] cała materia prima twórczości Jarosława jest mi tak bliska — od fantazmatów dzieciństwa, po identyczne ,referencje” kulturalne, aż po te same znajome twarze (co dziwniejsze - nie tylko polskie). Dzieje się tak, jakbym miał te same elementy w pamięci — niczym te szkiełka, które krążą w kalejdoskopie. Tyle że dla mnie to są szkiełka bezkształtne, a z zachwytem widzę, jak układają się, w lustrzanym pryzmacie twórczości Jarosława $[\ldots]^{205}$.

Stosunek do Iwaszkiewicza to nie tylko świadectwo określonej wrażliwości Jeleńskiego, to także wyraz jego zapatrywań na pewien paradygmat postępowania w określonych warunkach historycznych.

201 J. Mieroszewski, Dramat polskich „klerków”, Kultura 1955 nr 11(97), s. 74-81.

202 J. Iwaszkiewicz, T. Jeleńska, K. A. Jeleński, Korespondencja, s. 53.

${ }^{203}$ Tamże, s. 135.

${ }^{204}$ J. Giedroyc, Autobiografia na cztery ręce, s. 210.

${ }^{205}$ K. A. Jeleński, List do Jerzego Lisowskiego, fragment niepublikowanego rękopisu znajdującego się w zbiorach Muzeum Literatury im. Adama Mickiewicza w Warszawie; cyt. za: J. Iwaszkiewicz, T. Jeleńska, K. A. Jeleński, Korespondencja, s. 227. 
Mówiąc o politycznej orientacji Jeleńskiego nie można pominąć faktu jego przynależności do Kongresu Wolności Kultury, antykomunistycznej instytucji międzynarodowej powołanej w 1950 roku w Berlinie. Jak już mówiliśmy, w roku 1952 Jeleński przeniósł się z Rzymu do Paryża. Porzucił pracę w FAO i podjął nową w sekretariacie generalnym Kongresu. Od samego początku pobytu we Francji, nawiązywał kontakty z częścią Europy okupowaną przez ZSRR. Udało mu się także zorganizować we francuskim radio szereg audycji przeznaczonych dla Europy Wschodniej. W 1952 poznał François Bondy’ego - wspólnie wypracowali linię „Preuves”, francuskojęzycznego organu Kongresu. Kongres Wolności Kultury został rozwiązany w roku 1966, kiedy ujawniono, że, bez wiedzy jego członków, był finansowany przez CIA. Na jego miejsce powołano Międzynarodowe Stowarzyszenie dla Wolności Kultury. Warto jednak poświęcić Kongresowi choć kilka słów, traktując pracę Jeleńskiego w nim jako wybór świadomy i znaczący.

Temat Kongresu pojawia się w m.in. późnym tekście Jeleńskiego Krótka pamięć $\mathrm{z}$ roku 1986. Jest to drobna notatka na marginesie (rzekomej) wypowiedzi Leopolda Tyrmanda, komentującej rozejście się autora Złego z „Kulturą”, w której Jeleński wyczuł nieszczere fragmenty. W swoim tekście przywołuje artykuł Ryszarda Legutki (pseud. Marek Leski) Amerykański Tyrmand ${ }^{206}$, w którym autor, powołując się na słowa Tyrmanda, twierdzi, iż powodem była polityczna taktyka Jerzego Giedroycia, który dla sprawy polskiej wykorzystywał zachodnią lewicę intelektualną. Dlaczego taka opinia mogłaby uchodzić za zarzut wobec Giedroycia, a więc dlaczego pomoc inteligentów zachodniej lewicy miałaby być uznana za niewłaściwą? W tle (domniemanych) słów Tyrmanda błyszczy oczywiście ostrze wymierzone w kierunku Kongresu Wolności Kultury, którego figurą pars pro toto był w środowisku „Kultury” Jeleński — stąd może dość personalny ton jego odpowiedzi. Dlaczego pismo Giedroycia współpracowało z lewicowym Kongresem? Odpowiedź staje się jasna, kiedy zrozumie się istotę tej instytucji i ówczesną sytuację polityczną w Europie. Jeleński tłumaczy:

[...] Kongres Wolności Kultury [...] powstał w Berlinie w roku 1950 z inicjatywy czołowych przedstawicieli antykomunistycznej lewicy intelektualnej, którymi byli choćby Bertrand Russell, Koestler, Silone, Spender, Manes Sperber, Willy Brandt. Wielu z nich przeszło przez komunizm, co warto podkreślić dzisiaj, gdy zapomina się w kraju, ile przyczynili się eks-komuniści (również polscy) do ostatecznej demistyfikacji sowieckiego systemu.

Pamiętajmy też, że zachodnia prawica nie rozumiała wówczas totalitarnego sedna owego systemu. Jej antykomunizm miał cechy samoobrony w wewnętrznej polityce, a we Francji, gdzie partia komunistyczna była szczególnie potężna, prawicowi politycy starali się często o dobre stosunki ze Związkiem Sowieckim, w słusznym przekonaniu, że zostaną za to wynagrodzeni hamulcem nałożonym przez Moskwę na „rozkładowe”, jeśli nie „rewolucyjne” zapędy francuskiej partii ${ }^{207}$.

Jeleński zdawał sobie sprawę z faktu, że nie każdy musi być entuzjastą kooperacji $\mathrm{z}$ instytucją tego typu i byłby prawdopodobnie nie zareagował na artykuł Legutki, gdyby nie zakłamanie Tyrmanda, który, w latach 50., widział sprawy inaczej. Jeleński zamyka swoje króciutkie sprostowanie ustępem:

Tyrmand miał krótką pamięć. Będąc w Polsce, oświadczył w swym Dzienniku, po otrzymaniu „Preuves” z moim artykułem o sytuacji w kraju, że Kongres Wolności Kul-

\footnotetext{
${ }^{206}$ [R. Legutko] M. Leski, Amerykański Tyrmand, Arka 1985 nr 12, s. 22-31.

${ }^{207}$ K. A. Jeleński, Krótka pamięć, [w:] CO, s. 372-373.
} 
tury jest groźniejszym dla komunizmu przeciwnikiem... od prezydenta Stanów Zjednoczonych i papieża $^{208}$.

Ta niekonsekwencja musiała być dla Jeleńskiego rażąca.

Więcej o stanowisku Jeleńskiego na temat Kongresu dowiadujemy się z fragmentów rozmów zapisanych przez Barbarę Toruńczyk. Czytamy w nich:

Pomysł powstał w Ameryce. Kongres powstał ze scysji amerykańskich intelektualistów zgrupowanych wokół „Partisan Review”. To była scysja między tymi, którzy nadal byli stalinistami, a tymi, którzy się całkowicie od stalinizmu odcięli. [...] Kongres został założony przez ekskomunistów oczywiście. Motywacja była antykomunistyczna, wcale nie „kulturalna”. [...] Według mnie dosyć dużym osiągnięciem Kongresu i jego pism było to, że jak się zaczęła tzw. odwilż to cała prawica antykomunistyczna uważała to za fintę, za przejaw chytrości reżimu — że to jest taki wielki wilk w owczej skórze, więc że wszyscy rewizjoniści i cały ruch odwilżowy jest jeszcze groźniejszy dla Zachodu niż stalinizm. A Kongres tej opinii absolutnie przeciwdziałał. Więc jeżeli chodzi o Europę Wschodnią to było chyba głównym wkładem Kongresu. Bo zapomina się, do jakiego stopnia ludzie byli tutaj przeciwni tym zmianom na Wschodzie. Komuniści byli całkowicie przeciwni, wściekli po prostu, a antykomuniści byli bardzo niechętni wszystkim odwilżowym przejawom $^{209}$.

René Tavernier wspomina: „chciał być europejski, pro-amerykański, liberalny, przychylny wobec dekolonizacji, antymarksistowski i antykomunistyczny, ale z sercem na lewicy, po stronie socjalizmu o ludzkim obliczu"210 — Tavernier przywołuje charakter Kongresu, ale zapisana tu jego istota bliska była naturze samego Jeleńskiego. Znalazł się chyba we właściwym miejscu.

Etat Jeleńskiego w Kongresie (którego działalność dość szybko rozczarowała Giedroycia) i jednoczesna współpraca z „Kulturą” okazywały się z czasem trudne do pogodzenia. Jeden z wynikłych z tego połączenia konfliktów pojawił się w roku 1959, kiedy Giedroyc przekazał „Encounterowi”, angielskiemu pismu Kongresu, otrzymany z Moskwy, pełen rewelacji tekst Abrama Terca Sąd idzie, z tym jednak zastrzeżeniem, że opublikowany tekst poprzedzony będzie notą zaznaczającą, że jest on zdobyty przez „Kulturę”. Redaktor „Encountera”, Melvin Lasky, informacji tej nie umieścił. Sytuację tę klarownie opisuje Giedroyc w liście do Andrzeja Bobkowskiego z roku 1960:

[...] Jeleński jako Kongres prosił mnie o prawo przedruku Terca w „Encounterze”. Przedrukowali rzeczywiście, ale podając to w takiej formie, jakby to oni bezpośrednio zdobyli. Ma się rozumieć masa artykułów, jaka się ukazała w prasie angielskiej, wychwalała „Encounter”. Dla mnie był to poważny cios, gdyż była to możliwość wypły-

${ }^{208}$ Tamże, s. 373. W Dzienniku 1954 Tyrmanda czytamy: „Jak uprzednio Kisielowi i Jackowi, pokazałem Jerzemu numer «Preuves» z listopada ubiegłego roku. Jest to francuski organ Kongresu Obrony Kultury, jedynej poważnej instytucji na Zachodzie, w moim przekonaniu przynajmniej. Nic mnie nie obchodzi, skąd biorą pieniądze i kto im daje, ich walka z komunizmem ma sens i efektywność wielokrotnie donioślejszą i dotkliwszą niż wysiłki wszystkich demokratycznych liderów zachodnich z papieżem i prezydentem USA włącznie. Wydają «Preuves» i po niemiecku «Der Monat», pomagają polskiej «Kulturze» i angielskiemu miesięcznikowi «Encounter». Piszą i pracują dla nich wspaniali faceci: James Burnham, Karl Jaspers, Arthur Koestler, Ignazio Silone"; L. Tyrmand, Dziennik 1954, Londyn 1980, s. 322.

${ }^{209}$ K. A. Jeleński, „Preuves”. Strzępy rozmów, (zapis B. Toruńczyk), Zeszyty Literackie $1988 \mathrm{nr}$ 21, s. 196-197; por.: P. Grémion, Konspiracja wolności. Kongres Wolności Kultury w Paryżu (1950-1975), tłum. J. M. Kłoczowski, Warszawa 2004, passim, oraz M. A. Supruniuk, Przyjaciele wolności. Kongres Wolności Kultury i Polacy, Warszawa 2008, passim.

${ }^{210}$ R. Tavernier, Konstanty Jeleński czy tajemnica przyjaźni, Kultura 1987 nr 9(480), s. 36. 
nięcia na szersze wody dla „Kultury”. Na moje wrzaski Kongres Wolności powiedział, że „Encounter” jest niezależnym pismem, redaktor „Encountera” powiedział, że przecież nie będzie osłabiać wrażenia podawaniem źródła emigracyjnego, bo to kompromituje etc. Kot właściwie „Encounterowi” przyznał rację. Notą Mieroszewskiego ${ }^{211}$ bardzo obruszył się Kot, na co miał prawo, jako urzędnik Kongresu, ale wtrącił się Józio ze swoim obiektywizmem, że Kongres to nie Free Europe, nie show business etc. Wystosował gromki list do redakcji, który mu odmówiłem drukować. Były wobec tego gesty, że się wyprowadza, zrywa, Kot mobilizował możliwie wszystkich współpracowników „Kultury”, by wywrzeć na mnie nacisk etc. Wreszcie się zaklajstrowało. Ma się rozumieć, osad został, przynajmniej u mnie. Teraz tłumaczenie mi, że jestem megaloman i ośmieszam się występując przeciw Sowietom. „Z czym do gościa”. No, ale tym się nie przejmuję. Oni wszyscy mają kompleksy niższości. Czekać i być grzecznym, no i nie zanadto atakować Warszawy, bo to utrudnia i jest się reakcjonistą. Śmieszne to wszystko $^{212}$.

Sprawa ta, po której Londyńczyk pisał do Giedroycia: „Różnice polityczne miedzy nim a nami są tak wielkie, że [...] doszedłem do wniosku, iż nie ma nadziei byśmy się kiedyś zeszli z Jeleńskim" "13, rozogniła konflikt Jeleńskiego z Redaktorem, wynikający $\mathrm{z}$ rozbieżności $\mathrm{w}$ poglądach na linię pisma, która (tj. rozbieżność) stała się jasna już pod koniec lat 50. (W 1958 Jeleński opublikował tylko jeden tekst w „Kulturze”, w 1959 ani jednego.) Były one efektem różnic światopoglądowych w szerokim znaczeniu, tj. nie wyłącznie orientacji politycznych. Odrzucając w 1958 roku jeden z artykułów Jeleńskiego, Giedroyc skarżył się Mieroszewskiemu — jak się zdaje, kumulując swoje wszystkie związane z Jeleńskim frustracje:

Jak Pan wie, Jeleński dzięki naszym intrygom wszedł do Kongresu Wolności Kultury. Jest to organizacja, z którą byliśmy zaprzyjaźnieni i po której obiecywałem sobie dużo. Kongres nie potrafił - czy w małej mierze mu się udało — odegrać rolę na Zachodzie. Odcinek polski po październiku dzięki inteligencji Jeleńskiego i naszej inspiracji stał się dla nich atrakcyjny i na nim wyjechali, ratując swoje budżety czy kanalizując Fundację Forda. Od lat biegam koło Forda zarówno z projektami domu wydawniczego, pomocy intelektualistom, wysyłki książek etc. To mi się wymknęło z rąk na skutek tego, że Jeleński nie myśli politycznie. Nie uratowano ludzi z „Po prostu” ułatwiając im wyjazdy za granicę czy pomoc materialną, bo ,nie mieli kwalifikacji naukowych”, posyła się książki PAN, bo to ludzie z tytułami, a nie Krzywemu Kołu, bo to też nie ma stażu naukowego. Na odcinku literatury Jeleński ma słabość do Iwaszkiewiczów etc., lekceważąc innych. Dziś stawia na ewolucję partii, mimo że widzimy jasno, że partia nie chce żadnej ewolucji nawet $w$ tych granicach, które nie wywołałyby interwencji. Ponieważ Jeleński dysponuje dużymi możliwościami finansowymi i ma rozległe kontakty, więc zaczynają się wytwarzać dwa ośrodki, Przyboś nie chce rozmawiać z ,ludźmi z Maisons-Laffitte”, ale rozmawia z Jeleńskim. Kołakowski, którego od roku urabiam i strzelam się o jego stypendium, danie stypendium żonie etc. i który ze zrozumiałym ociąganiem się i wewnętrznymi oporami idzie w naszym kierunku, jest nagle przez Jeleńskiego ,usztywniany”. Nie chciałbym, by Pan mnie źle zrozumiał. W tym nie ma cienia nielojalności ze strony Kota. Wręcz przeciwnie, tylko to jest człowiek politycznie kompletnie niewyrobiony, który nie tylko nie zna Polski, ale i jej historii, ope-

211 J. Mieroszewski [Londyńczyk], Kronika angielska: „Encounter”- „Kultura”, Kultura 1960 nr 3(149), s. 102-103.

212 J. Giedroyc, A. Bobkowski, Listy 1946-1961, oprac. J. Zieliński, Warszawa 1997, s. 638.

${ }^{213}$ Fragment niepublikowanego listu Mieroszewskiego do Giedroycia z 20 grudnia 1959, znajdujący się w Archiwum Instytutu Literackiego, podaję za: A. St. Kowalczyk, Od Bukaresztu do Laffitów. Jerzego Giedroycia rzeczpospolita epistolarna, Sejny 2006, s. 232. 
rujący obsesjami (antykatolicyzm, antypiłsudskość, antyukrainskość, przesadny filosemityzm) i z dużym zmysłem przekory ${ }^{214}$.

„Kultura” według Jeleńskiego miała być możliwie najdalej od czynnego zaangażowania w sprawy polityczne. Zgoła odmienną wizję miał Giedroyc. W letnim numerze pisma z roku 1968 ukazuje się ostatni artykuł polityczny Jeleńskiego - Notatki o „majowej rewolucji”. Do 1975 publikuje w „Kulturze” bardzo niewiele ${ }^{215}$.

Giedroyc angażował przyjezdnych z kraju w przemyt swojego pisma do Polski. Dla Jeleńskiego było to zbędne, wręcz niedorzeczne ryzyko. W rozmowie z Izą Chruślińską Zofia Hertz wspomina:

Przez pewien czas miał Jeleński do nas pretensje o to, że narażamy ludzi z Polski dając im do przewożenia egzemplarze naszych książek czy miesięcznika. Było to po procesie „taterników” ${ }^{216}$. Ale potem Kot sam się z tego wycofał, przyznając nam rację ${ }^{217}$.

Sam Giedroyc mówił po latach w rozmowie z Barbarą Toruńczyk: „u Jeleńskiego to wychodziło z takich względów pryncypialnych: uważał, że należy robić pismo i tylko pismo. A inni się bali. Używali argumentu, że to jest narażanie ludzi w kraju (niby że ja wciągam ludzi z kraju w kontakty z «Kulturą»)"218. W innym wywiadzie dodawał:

Denerwował mnie jego pacyfizm. Trząsł się, że wysyłając literaturę do kraju, naraża się ludzi. Jednocześnie był człowiekiem wielkiej brawury osobistej, czasem wręcz śmiesznej. Dam przykład: w czasie inwazji w Holandii, na jakimś postoju, generał Maczek powiedział: „O, jakie piękne poziomki...”. Wiadomo, że rosły na terenie zaminowanym, ale Kot poskoczył i zaczął te poziomki zbierać... ${ }^{219}$.

Z Giedroyciem Jeleński rozmijał się również w spojrzeniu na emigrację: „Różniliśmy się też w postawie wobec emigracji londyńskiej, do której Kot miał stosunek pobłażliwy czy sympatyzujący. Grydzewski i krąg «Wiadomości» byli mu bardzo bliscy” — pisał Redaktor w Autobiografii na cztery ręce (s. 211). Jeleński był krytyczny wobec

${ }^{214}$ Zob.: A. St. Kowalczyk, Od Bukaresztu do Laffitów..., s. 229 (list z 10 maja 1958).

${ }^{215}$ W 1969 Jeleński napisał dla „Kultury” jeden tekst, tak samo w roku 1970 i 1971. W 1972 nie napisał ani jednego, po jednym zaś w 1973 i 1974. Ciężko jednoznacznie stwierdzić, czy przyczyną tego, że w tych latach, jak i w latach poprzednich, kiedy teksty Jeleńskiego nie były publikowane na łamach „Kultury” (lub było ich bardzo niewiele), była niechęć Jeleńskiego do pisma (lub odwrotnie), bądź też po prostu nadmiar obowiązków, związanych z pracą etatową w instytucjach francuskich. Niemniej jednak Notatki o majowej rewolucji były ostatnim tekstem Jeleńskiego w „Kulturze”, w którym występował — bezpośrednio — w roli komentatora politycznego. A w piśmie tym — przypomnijmy — publikował do roku 1987.

${ }^{216}$ Proces taterników odbył się w roku 1970. Władze PRL oskarżyły Macieja Kozłowskiego, Jakuba Karpińskiego, Małgorzatę Szpakowską, Marię Tworkowską i Krzysztofa Szymborskiego o przekazywanie wrogim ośrodkom informacji (w tym dotyczących polskiego Marca 68') szkalujących PRL oraz przemyt (przez polsko-czechosłowacką granicę w Tatrach) podobnych materiałów do kraju, w tym również „Kultury” i publikacji Instytutu Literackiego; zob.: J. Karpiński, Taternictwo nizinne, Paryż 1988 i wyd. nast.

${ }^{217}$ I. Chruślińska, Była raz „Kultura”..., s. 81. Sytuację tę w rozmowie z Renatą Gorczyńską wspomina Gustaw Herling-Grudziński: ,[Jeleński] bardzo na tym cierpiał. Długo to trwało, ale zostało w końcu złagodzone. Nie chcę tu wchodzić w szczegóły, ale Kot nie miał racji. [...] Przez jakiś czas przed kłótnią z Giedroyciem prowadził kronikę francuską. Gdyby wszystko toczyło się normalnie, to on powinien był zostać ambasadorem polskim w Paryżu. Byłby fenomenalny w tej roli”; R. Gorczyńska, Portrety paryskie, s. 209.

${ }^{218}$ B. Toruńczyk, Rozmowy w Maisons-Laffitte, s. 89.

${ }^{219}$ E. Berberyusz, Książę z Maisons-Laffitte, Gdańsk 1995, s. 90. 
emigracji, ale - chyba w przeciwieństwie do Redaktora - umiał rozmawiać ze wszystkimi. Nie zmienia to jednak faktu, że jego oddanie dla „Kultury” było wyjątkowe. Po latach, w wywiadzie z roku 1986 wyznaje:

\begin{abstract}
Jako „uchodźca polski” związałem się z „Kulturą”, która mi odpowiadała dlatego, że była bardzo antyemigracyjna, opozycyjna w stosunku do całej emigracji, do rządu i do całego establishmentu emigracyjnego. Pracować w „Kulturze” to było wówczas rzeczywiście pracować w piśmie bardzo niekonformistycznym. [...] Uważam, że „Kultura” była najlepsza w tym czasie, w czasach stalinowskich. Nie miała co prawda żadnej konkurencji. Jest to może tylko moja iluzja, ale różnica poziomu pomiędzy pismami krajowymi a „Kulturą” w latach 1949-1956, i również „Wiadomościami” londyńskimi była olbrzymia 220 .
\end{abstract}

Giedroyc, skory do utrzymywania stosunków z dysydentami, był ponadto, w przeciwieństwie do Jeleńskiego, dość nieufny w stosunku do odwilżowych rewizjonistów i ludzi związanych z reżymem, z którymi Jeleński z kolei utrzymywał kontakty i w których pokładał wielkie nadzieje. W liście do Leopolda Tyrmanda z roku 1967 Giedroyc pisał:

Kot Jeleński [...] chce za wszelką cenę mieć dobre stosunki z polskim establishmentem, odnosząc się niechętnie do wszelkiej opozycji. Na tym tle rozstaliśmy się już dobre 6-7 lat temu ${ }^{221}$.

\title{
Tymczasem, jak zauważa Pierre Grémion:
}

W oczach Jeleńskiego rewizjonizm nie jest wyłącznie neomarksistowską reakcją na stalinowski totalitaryzm, zainicjowaną przez młodych komunistów w Polsce i na Węgrzech. W o wiele szerszym kontekście, oznacza on zmniejszanie się wpływu ideologii millenarystycznych na intelektualistów i na opinię publiczną w ogólności. Zmiana ta jest widoczna zarówno w świecie zachodnim jak i w świecie komunistycznym ${ }^{222}$.

Trzeba także powiedzieć, że wiele idei ich oczywiście łączyło. Zgodni byli chociażby w poparciu Gomułki. W liście do Giedroycia z roku 1956 Jeleński klarował swoją wizję:

W stosunku do Polski mamy, wydaje mi się, bardzo silne karty: byliśmy jedyni na emigracji od dawna popierający „,gomułkowszczyznę”; nigdy nie traktowaliśmy „narodowego komunizmu" jako cel ostateczny. Stąd możemy, myślę, stawiać tezę następującą: naród polski powinien popierać Gomułkę i zrozumieć konieczność pozostania w bloku sowieckim tak długo, jak, nieuniknione już chyba, nie zajdą przemiany w samym Związku Sowieckim. Im głębiej Kreml będzie przekonany o szczerości Polski, to znaczy o głębokim zrozumieniu, że alians sowiecki jest tymczasem koniecznością, tym dalej może pójść Polska na drodze uniezależnienia wewnętrznego i swobody. Myślę, że w ramach Związku Sowieckiego i świata komunistycznego w ogóle zajdą niedługo (w ciągu kilku lat) zmiany, które pozwolą, jeśli nie na parlamentarną demokrację, to na istnienie trzech partii: komunistów (,narodowych”), „dżilasów” — czyli ludzi, którzy z komunizmu wyszli czy przez komunizm przeszli, ale którzy zbliżają się do koncepcji bevanowskich — wreszcie katolików (w Polsce) — w innych krajach odpowiednika

${ }^{220}$ K. A. Jeleński, „Nigdy nie emigrowatem z Polski...”, rozmowę przeprowadził i oprac. S. Rosiek, Zeszyty Literackie 1988 nr 61, s. 137.

${ }^{221}$ Fragment niepublikowanego listu Giedroycia do Tyrmanda z 3 sierpnia 1967, znajdującego się w Hoover Institutions Archives, Stanford University, California; podaję za: J. Korek, Paradoksy paryskiej „,Kultury”, Lublin 2000, s. 371.

${ }^{222}$ P. Grémion, Konspiracja wolności..., s. 201. 
„narodowego” czy „tradycyjnego” (w Rosji nie wykluczałbym tu aliansu armii z prawosławiem). Myślę, że nawet jeśli nasze sympatie szłyby raczej w kierunku „dżilasowców”, trzeba na daleką metę wytłumaczyć komunistom, że im „lepiej” rządzić będą w okresie monopartii, tym większe będą ich szanse, kiedy dojdzie do nieuniknionej konkurencji z innymi ${ }^{223}$.

Był konsekwentny. W liście trzy lata wcześniejszym odnajdujemy fragment:

[...] jeśli nie w pierwszych, to w drugich wyborach ,,wolnych” w Polsce spore znaczenie osiągnie partia byłych „reżymowców” (czy wystąpi jako narodowi komuniści, czy jako socjaliści, to obojętne). [...] wydaje mi się, że przyjdzie może czas na zastanowienie się, czy nie należy ze strony polskiej emigracji nawiązać ściślejszego kontaktu z Titem, Bevanem itd. Jeśli chodzi o mnie, to kiedy myślę o przyszłej Polsce (w jakiejkolwiek formie by powstała), najważniejszym zagadnieniem jest liberalizacja życia (prywatnego i umysłowego). Ale wydaje mi się coraz bardziej oczywiste, że ta liberalizacja będzie mogła być dokonana tylko od wewnątrz w ramach skrajnego radykalizmu społecznego i z udziałem ludzi ,skompromitowanych” przez udział w reżymie ${ }^{224}$.

Jeleński posiadał zatem konkretne wizje rozwoju Polski. Daleki był jednak od zaangażowania Giedroycia, które często uniemożliwiało Redaktorowi rozwiązania kompromisowe. Polityczna walka była żywiołem Giedroycia. Dystans Jeleńskiego często go mierził:

Był, jak na mój gust, zbyt oderwany od rzeczywistości polskiej. Miałem wrażenie, a Józio [Czapski] miał podobne, gdyż pamiętam rozmowy z nim na ten temat, że korzenie polskie Kota uległy pewnemu osłabieniu. Był nazbyt kosmopolityczny. Nie uważam, by mówiąc o słoniu należało zaraz przywołać sprawy polskie. Ale sprawy polskie są dla mnie na pierwszym miejscu. One nie zajmowały pierwszego miejsca u Jeleńskiego. Może dlatego, że czuł się on równie dobrze we Włoszech czy we Francji. Nie był emigrantem, a myśmy byli emigrantami. Polska nie doskwierała mu tak jak nam. Nie kwestionuję bynajmniej jego patriotyzmu podczas wojny i później, gdy tłumaczył poezję polską i propagował literaturę polską. Tu jego zasługi są bezsporne ${ }^{225}$.

Swoją rezerwę Jeleński tłumaczył Giedroyciowi w listach wielokrotnie. Już w roku 1953 pisał:

Co do mojego braku namiętności ma Pan zapewne rację. Zastanawiam się zresztą, czy można się naprawdę pasjonować polityką prowadzoną $\mathrm{z}$ emigracji — poniekąd w abstrakcji. Może Pana pasja do akcji dlatego jest tak żywa, że zaczęła się w czasach, kiedy mógł Pan mieć konkretny wpływ na wypadki. Nawet jako małego chłopca w Polsce pewne sprawy polityczne przejmowały mnie bardziej emocjonalnie niż dziś. Gdyby moja formacja zakończyła się w Polsce, gdybym na przykład poznał Pana z czasów „Polityki”, może nie miałbym tego pewnego détachement, które Pana zawsze trochę irytuje ${ }^{226}$.

Problem jednak powracał. Naciski i wyrzuty Giedroycia Jeleński przyjmował z opanowaniem. W liście do Redaktora z 1958 odnajdujemy fragment:

Mówi Pan zawsze, że mnie ,nic nie obchodzi”. To nie jest zupełnie prawda. Tylko w moich stosunkach z Panem przechodzę przez różne fazy. Niezmienną ich cechą jest pewna „fascynacja” Pana charakterem i inteligencją — tym bardziej, że jest odmienna

\footnotetext{
${ }^{223}$ J. Giedroyc, K. A. Jeleński, Listy..., s. 256.

${ }^{224}$ Tamże, s. 150.

${ }^{225}$ J. Giedroyc, Autobiografia..., s. 210.

${ }^{226}$ J. Giedroyc, K. A. Jeleński, Listy..., s. 185.
} 
od mojej — no i oczywiście moja lojalność względem Pana „,na zewnątrz”. Ale czasami wykonuję Pana polecenia bez żadnego zapału — w pewnej mierze „na wiarę”, trochę dlatego, że wiem, że mimo takich czy innych zniechęceń łączy nas na pewnym poziomie jakieś wzajemne zrozumienie, które bardzo często odnajduję. Nieraz zapalałem się naprawdę do Pana planów. Ale na to, żeby móc w nich jakoś uczestniczyć, muszę Panu od czasu do czasu powiedzieć, jakie są moje wątpliwości. Pan ma tendencję do zbywania ich argumentami poniekąd ad personam — że właśnie nie mam „entuzjazmu” itd. Ale wydaje mi się, że różnice są jednak bardziej sur le fond du problème ${ }^{227}$.

Jeleński nie był obojętny wobec sprawy polskiej, mało tego — działał nie tylko piórem, był aktywny.

Jak już wspomnieliśmy ostatnim politycznym tekstem Jeleńskiego w „Kulturze” był esej Notatki o „majowej rewolucji” z roku 1968. Poszukując analogii można zaryzykować stwierdzenie, że stosunek Jeleńskiego do paryskich wydarzeń z maja roku 1968 był w jakiejś mierze podobny do jego spojrzenia na kulturę masową. Popierał, z entuzjazmem reagował na rozmaite hasła, doskonale zdając sobie jednocześnie sprawę (w tym wypadku) z utopijności niektórych postulatów. Ale — jak sam pisze — „do pewnego stopnia, poza studentami na barykadach, poza reakcyjną burżuazją, cały Paryż cierpiał w tym historycznym maju na podobny dualizm" ${ }^{\text {"28 }}$. Studencka rewolucja była dla Jeleńskiego powiewem świeżości, aktywności młodzieży, z którą lubił się utożsamiać:

W ciągu maja Paryż schudł, wypiękniał, atmosfera stała się nagle braterska i serdeczna. Ludzie mówili ze sobą na ulicach, Sorbona i Odeon na krótko wskrzesiły tradycje prawdziwie demokratycznej agory. Studenci, którzy pozornie interesowali się tylko jazzem i kaszmirowymi swetrami, wykazali odwage, jakiej nigdy nie widziałem w manifestacjach opozycji w czasie wojny algierskiej, w których uczestniczyłem ${ }^{229}$.

Jako racjonalista wiedział jednak, że szanse na zainicjowanie poważniejszych zmian nie były wielkie:

Po raz pierwszy od pięćdziesięciu bodaj lat, rewolucja była tu młoda, wolna, niezależna od aparatów, zarazem utopijnie bezkompromisowa i liberalna, ale również całkowicie oderwana od społecznej i gospodarczej rzeczywistości, pozbawiona jakiegokolwiek konkretnego programu, nieuchronnie skazana na klęskę swych marzeń, niezależnie od rozwoju wypadków ${ }^{230}$.

Sama jednak inicjatywa, nieugiętość tych młodych ludzi, braterstwo, które na chwilę połączyło całe miasto, duch nie do końca określonej opozycji i chęci zmiany imponowały Jeleńskiemu. Dla wielu entuzjazm, jaki wywołały u niego paryskie wydarzenia majowe, zadecydował o doczepieniu mu etykietki radykalnego zwolennika tego ruchu. Miłosz pisze w Roku myśliwego:

Nie wiem, jak bym się odniósł do rewolucji lat sześćdziesiątych na Sorbonie — pewnie nie byłbym za ścinaniem platanów na bulwarze St. Michel, żeby z nich budować barykady. Zdaje się, że tutaj poglądy moje i Kota Jeleńskiego się różniły ${ }^{231}$.

\footnotetext{
${ }^{227}$ Tamże, s. 283-284.

${ }^{228}$ K. A. Jeleński, Notatki o „majowej rewolucji”, s. 152.

${ }^{229}$ Tamże, s. 152.

${ }^{230}$ Tamże, s. 151.

${ }^{231}$ Cz. Miłosz, Rok myśliwego, s. 288.
} 
Sam Jeleński zaznaczał jednak w tekście: „Idee, na których była oparta rewolucja majowa wydają się bądź anachroniczne bądź utopijne". Wyczuwalna była po raz kolejny osobliwa ambiwalencja Jeleńskiego - za, a nawet przeciw?

Dzięki możliwościom jakie dawał Kongres, Jeleński podejmował różne inicjatywy społeczne. Jedną z nich było zorganizowanie na fali „odwilży” w 1955 roku w Zurychu spotkania redaktorów naczelnych pism literackich ze Wschodu i Zachodu. Przewodniczył mu Ingazio Silone, a udział w nim wzięli przedstawiciele Polski, Jugosławii, ZSRR, Francji, Włoch i Wielkiej Brytanii. Jego efektem było założenie przez Jeleńskiego, wraz Silonem i Danielem Bellem, „Komitetu pisarzy i wydawców dla europejskiej samopomocy" z siedzibą w mieszkaniu Jeleńskiego, któremu zależało na zdystansowaniu się od działań Kongresu. Celem szwajcarskiego stowarzyszenia była pomoc intelektualistom krajów Europy Wschodniej i Środkowej poprzez wysyłkę książek i pism zachodnich ${ }^{232}$. Spiritus movens tych działań był Jeleński, który pomógł opracować listę odpowiednich lektur, przetłumaczonych następnie na wszystkie języki Europy Wschodniej i rozsyłanych na zamówienie. Z czasem stowarzyszenie udzielało także prenumerat pism literackich i naukowych oraz stypendiów na pobyty w demokratycznych krajach Europy Zachodniej. Pomagało także młodym malarzom poprzez organizowanie im wystaw w Paryżu.

Na miejsce rozwiązanego w 1966 Kongresu Wolności Kultury powołano Międzynarodowe Stowarzyszenie dla Wolności Kultury, które finansowała już w pełni Fundacja Forda. W tym samym roku rozwiązano Komitet. Na jego miejsce z kolei powstała Fundacja Europejska dla Samopomocy Intelektualnej. Przystąpił do niej Pierre Emmanuel, któremu także nieobce były projekty pomocy opozycji kulturalnej. Od 1959 należał do Sekretariatu Międzynarodowego Kongresu, gdzie zajmował się wspieraniem intelektualistów z Hiszpanii i Portugalii. Fundacja, w której Jeleński nadal pełnił bardzo istotną rolę, była m.in. organizatorem polsko-francuskiego kolokwium, zorganizowanego w pierwszą rocznicę wprowadzenia stanu wojennego w Polsce, poświęconego kondycji i rozwojowi społeczeństwa polskiego. Referaty w Bibliotece Polskiej w Paryżu wygłosili Bohdan Cywiński, Wojciech Skalmowski, Krzysztof Pomian, Leszek Kołakowski, Aleksander Smolar oraz sam Jeleński, który w sprawozdaniu ze tego spotkania pisał o swoim przemówieniu:

Tematem referatu Konstantego Jeleńskiego były „Paradoksy polskiego nacjonalizmu”. Przypomniał on słuchaczom, że dla człowieka jego pokolenia, który miał 13 lat w chwili śmierci marszałka Piłsudskiego (wroga numer jeden polskich nacjonalistów), pojęcie „Polaka-katolika” ma wydźwięk ponury, gdyż kojarzy się z faszyzującymi bandami, kokietowanymi przez zagubionych spadkobierców Piłsudskiego. „Polak-katolik”

232 O tej inicjatywie pisał Jeleński do Iwaszkiewicza w 1957: „Zmontowałem coś zupełnie na własną rękę (to jest poza Kongresem, choć z pomocą kilku znajomych). Jest to Komitet Wydawców i Pisarzy, którego zadaniem jest wysyłanie książek (głównie naukowych a w żadnym razie politycznej «propagandy») — do Europy Wschodniej, to jest, mówiąc dziś konkretnie, do Polski. Komitet jest pod przewodnictwem Guido Piovene, należą do niego między innymi John Lehman, Philip Toynbee, Raymond Aron, Georges Friedman, Paul Flamand (dyrektor Editions du Seuil), Livio Garzanti. Dostaliśmy trochę pieniędzy od Ford Fundation. Sekretarzami są Éric de Dampierre, młody lewicowy socjolog francuski i ja. Piszę to, bo chociaż głównym celem jest posyłanie książek do profesorów uniwersytetów itd. - jeśli chodzi o wybitnych pisarzy, też możemy coś zrobić. Także jeśli potrzebujesz jakichś książek czy czasopism - napisz proszę"; J. Iwaszkiewicz, T. Jeleńska, K. A. Jeleński, Korespondencja, s. 47. O Komitecie Pisarzy i Wydawców zob.: P. Grémion, Od Komitetu Pisarzy do Fundacji Wzajemnej Pomocy Intelektualistów w Europie, [w:] tegoż, Konspiracja wolności... 
to dla Jeleńskiego pojęcie przeciwstawne wartościom zarówno Polaka jak i katolika: „Logiczne jest twierdzenie, że katolik świadomy tradycji swego kraju i zasad swej religii «Polakiem-katolikiem» być nie może ${ }^{, 233}$.

Wspólne koncepcje Emmanuela i Jeleńskiego ${ }^{234}$ dały także owoce w postaci inicjatyw translatorskich, którym obaj się poświęcili. Jednym z ich celi było wydanie po francusku serii antologii poezji. Po opracowaniu przez Ladislasa Garę antologii poezji węgierskiej, Jeleński rozpoczął pracę na antologią polską, a Emmanuel jugosłowiańską.

\section{Przekazać nieprzekazywalne}

„Od dawna jestem przekonany, że jedyną doskonałą lekturą książki jest jej przetłumaczenie na obcy język" — tym zdaniem Jeleński rozpoczyna esej Tajny ładunek korsarskiego okrętu z roku 1976, będący refleksją na marginesie własnego francuskiego tłumaczenia Trans-Atlantyku ${ }^{235}$. Tłumaczenie było dla Jeleńskiego najbliższą możliwą formą obcowania z tekstem. Często wynikało z pobudek osobistych, z własnych potrzeb.

Największym chyba jego osiągnięciem w tej dziedzinie było opracowanie antologii poezji polskiej w języku francuskim. Tom Anthologie de la Poésie polonaise ukazał się w roku 1965 w znanym paryskim Éditions de Seuil (drugie wydanie, uzupełnione, wydała w serii „Collection Classiques Slaves” lozańska oficyna L'Âge d'Homme w roku $\left.1981^{236}\right)$. O pracy Jeleńskiego pisze w przedmowie do pierwszego wydania Czesław Miłosz:

[...] mój przyjaciel Konstanty Jeleński, redaktor antologii, wybrał rozwiązanie nieco ryzykowne, ale, jak się okazało, jedynie trafne. Chcąc dać obraz poezji polskiej od średniowiecza po młodych poetów dzisiejszych, zaprosił do współpracy ekipę poetów francuskich nie żądając od nich niemożliwości, to jest ślęczenia nad nieprzystępną gramatyką. Dostarczał im przekładów dosłownych i analizował z nimi wzory metrycz-

233 [K. A. Jeleński] K.A.J., Polska: Sierpień 1980 - Grudzień 1982 (Swoiste cechy i dynamizm polskiego spoteczeństwa), Kultura $1983 \mathrm{nr}$ 1-2(424-425), s. 49. Referaty z tego kolokwium zostały wydane w zbiorze pod tytułem Solidarité résiste et signe. Actes du Colloque Pologne, Août 1980 - Décembre 1982. Originalité et dynamisme d'une société, Paris 1982.

${ }^{234}$ Więcej o współpracy Jeleńskiego z Emmanuelem w Fundacji zob.: P. Grémion, Od Komitetu Pisarzy do Fundacji Wzajemnej Pomocy Intelektualistów w Europie, [w:] tegoż, Konspiracja wolności. Kongres Wolności Kultury w Paryżu (1950-1975), tłum. J. M. Kłoczowski, Warszawa 2004, s. 259-278.

${ }^{235}$ Przekład powieści Gombrowicza, Trans-Atlantique, dokonany przez Jeleńskiego wspólnie z Geneviève Serreau, ukazał się w serii „Les Lettres Nouvelles” nakładem Denoël w Paryżu w roku 1976.

236 O tym wydaniu pisał Jeleński w liście do Iwaszkiewicza z 1979: „moja A n th o lo g i e de la Poésie Polona is e jest już od roku z górą wyczerpana - w Editions du Seuil nie chcieli wydać na nowo (tak jak wszyscy wielcy wydawcy, są teraz niewolnikami Compu te $\mathrm{ra}$, który im tego wznowienia zabronił). Zaproponował mi ponowne wydanie mej antologii Vladimir Dimitrijevic (dyrektor i właściciel L'Âge d'Ho mme w Lozannie - wydawca slaviców różnych - między innymi całego Witkacego). Antologię wydrukuje z mikrofilmu pierwszego wydania - ale daje mi do dyspozycji 50 dodatkowych stron na zapełnienie luki 1964-1979. Zamiast naprawiać zapomnienia, dawać po kilka wierszy różnych poetów nowych, mam zamiar ograniczyć się w tym Postscriptum do 6 poetów: Iwaszkiewicz, Miłosz, Różewicz, Białoszewski, Herbert i jeden z poetów grupy 1970. Przeciętnie wypadnie z 6-7 stron na poetę - tego samego wymiaru i składu, co w pierwszym wydaniu" [podkr. - K. A. J.]; J. Iwaszkiewicz, T. Jeleńska, K. A. Jeleński, Korespondencja, s. 261. 
ne. Przyznaję, że kiedy parę lat temu zabierał się do pracy, byłem nieco sceptyczny co do wyniku. W miare jednak jak antologia rosła, mój sceptycyzm zmieniał się w podziw i dla redaktora spędzającego nieraz całe godziny na wyjaśnianiu tłumaczom zawiłości jednej strofy, i dla dobrego metiér całej ekipy. W ten sposób, przez kolejne zamówienia, z dużym udziałem konkursu (bo jeden wiersz był nieraz tłumaczony przez wielu poetów i wybierana wersja najlepsza), przy wykorzystaniu przekładów już istniejących, jeżeli odpowiadały wymaganiom, powstała książka, którą nie zawaham się nazwać pierwszą antologią poezji polskiej w języku francuskim ${ }^{237}$.

Opracowanie antologii literackiej nie mogło być rzeczą łatwą, z wielu powodów. Po pierwsze dyskusyjny może być zawsze system selekcji i — co oczywiste — jej efekty. Są różne antologie, ale tematyczny dobór utworów jest zawsze mniej skomplikowany od tych wyborów, które mają ambicję ukazać całość w przekroju. Rzecz wymaga wielkiej pracy i wiedzy, staje się dodatkowo skomplikowana w momencie, kiedy ma być przeznaczona dla czytelnika z innego kraju. Jeleński podjął się tego zadania. Zależało mu na obiektywnej panoramie polskiej poezji, ale nie ukrywa, że część (choć niewielka) wyborów wiązała się z jego osobistymi upodobaniami. Całość miała być jednak świadectwem różnorodności polskiej poezji. W wyborze nieoceniona okazała się pomoc trzech wybitnych poetów:

Wat zwrócił uwagę na wiersze dziwne, przez oficjalną krytykę traktowane pogardliwie, a które wydają mi się jednymi z najpiękniejszych w tej antologii — na przykład na Pająka Czajkowskiego. Jan Brzękowski wspomógł mnie swoją znajomością teorii awangardowych. Natomiast dzięki Czesławowi Miłoszowi doceniłem „historyczność” poezji polskiej $^{238}$.

Polski nie jest językiem prostym. Trudność potęguje jego poetyckie wcielenie: różne kombinacje metryczne (i konkretna prozodia), bogate słownictwo, swobodna gramatyka, wszechpanująca fleksja, neologizmy i częste formy pochodne, zdolność (i swoista predylekcja) do zwięzłości, o którą nie tak łatwo w innych językach ${ }^{239}$. Jeleński jednak konsekwentnie pracował nad kolejnymi utworami, zapisując — o czym wspomina Miłosz - dosłowne tłumaczenia, do których załączał następnie noty o prozodii. Współpracowało z nim w sumie ponad pięćdziesięciu tłumaczy francuskich. On sam jest autorem kilkunastu tłumaczeń zawartych w zbiorze — jego nazwisko jako tłumacza figuruje m.in. przy utworach Białoszewskiego, Szymborskiej, Herberta, Przybosia, Wata, Wierzyńskiego i innych. Jeleńskiemu bardzo zależało na ukazaniu się tego tomu, przede wszystkim chyba z potrzeby dzielenia się pięknem samej poezji. Kierowała nim chęć przekazania czytelnikowi francuskiemu ,przyczyn” jego osobistych, ,utrwalonych chwil zachwytu”.

Antologia obejmuje sześć wieków polskiej poezji (1400-1980) — każdy reprezentowany jest przez kompetentnie dobranych poetów, choć część utworów, które być może dla polskiego czytelnika obowiązkowo powinny znaleźć się w takim wyborze, nie weszła do zbioru, często z powodu swej osobliwej „nieprzekładalności”. Wrażliwość Jeleńskiego-czytelnika zdaje się najbardziej ożywiać w kontakcie z poezją XX wieku, której poświęcono ponad połowę tomu. Tu też, ujawniają się nieśmiało jego prywatne upodobania. Ponadto, tam, gdzie to możliwe, Jeleński unika raczej w swoim wyborze liryki religijnej.

${ }^{237}$ Cz. Miłosz, O poezji polskiej, Kultura 1964 nr 9(203), s. 33.

${ }^{238}$ K. A. Jeleński, Ttumaczyć poezjęe, przeł. T. Stróżyński, Akcent 1988 nr 1, s. 45-51 [posłowie do książki Anthologie de la poésie polonaise, Éditions L'Age d’Homme, Lozanna, 1981 13. Por. tamże, s. 48-50. 
Wydanie antologii Jeleńskiego nie pozostało bez komentarza w Kraju. Znamienną jest tu dyskusja z roku 1966 przeprowadzona przez Juliana Przybosia, Artura Sandauera, Janusza Wilhelmiego i Macieja Żurowskiego, której zapis opublikowała warszawska „Kultura” ${ }^{, 40}$. Pierwszy Sandauer:

Co do mnie - wydaje mi się przede wszystkim wątpliwy sam dobór tekstów. Dokonano go nader stronniczo, kierując się interesami emigracyjnej grupy i wysuwając na czoło poetów nieraz trzeciorzędnych ${ }^{241}$.

Dalej atakuje Wata, który brał udział w opracowaniu tomu, a którego wierszy jest w zbiorze więcej niż chociażby Leśmiana czy Broniewskiego. W ofensywie na Wata wtóruje Sandauerowi Przyboś:

Jak rozepchano książkę pustosłowiem tego symulanta! (Symulował chorobę, ażeby naiwna Polska Ludowa fundowała jemu i żonie długotrwałe podróże zagraniczne, aż w końcu „wybrał wolność”). Ale poezji symulować się nie da... ${ }^{242}$.

Kolejny zarzut Sandauera dotyczy wyboru twórczości Jastruna i Ważyka - antologia pomija w ich przypadku lata 1939-1956, jako niewygodne, twierdzi Sandauer, dla którego jest to ich najlepszy okres. Żurowski posuwa się najdalej, mówiąc: „według mnie, wszystko w tej książce jest nieporozumieniem”. Poddaje także w wątpliwość talent większości tłumaczy. „Miałka i pretensjonalna jest przedmowa Czesława Miłosza" — dodaje.

Jeleński nie czekał długo z odpowiedzią. Pod koniec stycznia 1966, w liście do Wata anonsował:

Pojutrze odpowiadam przez radio (Wolna Europa) na obrzydliwą dyskusję w warszawskiej „Kulturze”. [...] Mam zamiar całość tego tekstu radiowego opublikować w „Kontynentach” (nie chcę w „Kulturze”, bo, jak wiesz, Giedroyc wyobraziłby sobie, że mi robi łaskę). Tekst jest zresztą udany — myślę — bo udało mi się zbić wszystkie ich zarzuty i trochę tę bandę ośmieszyćc ${ }^{243}$

Swoje wyjaśnienie rozpoczyna od obszernej obrony Wata, podkreślając „oszczerstwo i kłamstwo" Przybosia, oskarżającego autora Ciemnego świecidta o symulowanie choroby. Mówi ponadto:

Julian Przyboś zapomniał chyba, że Aleksander Wat był laureatem nagrody literackiej „Nowej Kultury” — tak, tejże samej „N.K.”, której „Kultura” jest kontynuacją — w r. 1957! Zadziwiająca jest bezczelność Sandauera i Przybosia, którzy mnie przypisują polityczne motywy, podczas gdy oni sami stosują czysto stalinowski chwyt, przekreślając ze względów oczywiście politycznych dorobek wybitnego poety polskiego [... $]^{244}$.

W części tekstu Jeleńskiego pojawia się pewna nieścisłość. Odpierając ataki Przybosia przypomina, że Aleksander Wat był w istocie człowiekiem bardzo chorym, co było

${ }^{240}$ Zob.: J. Przyboś, A. Sandauer, M. Żurowski, J. Wilhelmi, $O$ „Antologii poezji polskiej” mówiq..., Kultura (Warszawa) 1966 nr 3, s. 1, 8.

${ }^{241}$ Tamże, s. 1.

${ }^{242}$ Tamże.

${ }^{243}$ A. Wat, Korespondencja, cz. 2, oprac. A. Kowalczykowa, Warszawa 2005, s. 146-147.

${ }^{244}$ Zob.: K. A Jeleński, Odpowiedź na partyzantkę krytyków, Kontynenty 1966 nr 88, s. 410; tu cyt. za: A. Wat, Korespondencja, cz. 2, s. 147. Antologii Jeleńskiego bronił na łamach pisma Giedroycia Józef Czapski; zob.: J. Czapski, Czarny kamień, Kultura 1966 nr 4(222), s. $120-123$. 
rezultatem lat spędzonych w sowieckich więzieniach. Ze względów zdrowotnych wyjechał w roku 1957 na stypendium rządowe — przyznaje Jeleński — ale

już w 1958 znalazł samodzielną pracę u włoskiego wydawcy Silvy i ciężko zarabiał na życie przez pięć lat, zanim poprosił w r. 1963 o azyl polityczny we Francji, skazując się przez to samo na twarde życie tułacze, bo przecież w Polsce miał zapewnione równie dobre warunki materialne jak Przyboś czy Sandauer ${ }^{245}$.

Sprostować należy jednak, że Wat pracował u Silvy od roku 1960. Z tym faktem wiąże się z kolei wydanie następnej obcojęzycznej pozycji opracowanej przez Jeleńskiego, o której warto wspomnieć.

Na początku 1960 roku Wat został zaangażowany przez Umberta Silvę do jego firmy wydawniczej Silva Editore w Mediolanie, jako redaktor kolekcji polskiej i rosyjskiej. W serii polskiej ukazał się w roku 1961 zbiór La realtà dell'ottobre polacco (Rzeczywistość polskiego Października), będący sporządzoną przez Jeleńskiego antologią tekstów z tygodnika „Po prostu”. O wydaniu takiej antologii Jeleński myślał już wcześniej — od 1958 przygotowywał ją dla francuskiego wydawcy Calmann-Lévy. Nie opublikowano jej wówczas w Paryżu — trzy lata później udało się natomiast wydać tom po włosku, przy współpracy z Watem, jako przedstawicielem Silvy.

Jeleńskiemu podobała się odwilżowa linia „Po prostu”. Pismo, pozbawione wcześniej jakiegokolwiek znaczenia, nie bez powodu osiągnęło w październiku 1956 roku 150-tysięczny nakład ${ }^{246}$. Na jego łamach otwarcie krytykowano dotychczasową władzę, odsłaniając prawdę o stalinowskiej rzeczywistości. Starano się wprowadzić nowy rodzaj dyskursu, zarówno pod względem językowym jak i światopoglądowym. Pismo dopuszczało pluralizm sądów, otwarte na opinie czytelników publikowało liczne polemiki, gwarantowało demokratyczną dyskusję. Redaktorzy „Po prostu” domagali się komunizmu z ludzką twarzą, powrotu do autentycznej myśli marksistowskiej, uwolnionej od ideologicznego dogmatu. Tygodnik szybko stał się także ośrodkiem życia politycznego, silnie kojarzonym z ideami antystalinowskiej odnowy. Po poparciu Gomułki i szybkim rozczarowaniu jego polityką, pismo domagało się spełnienia odwilżowych postulatów. To stanowisko okazało się nie do przyjęcia dla władz, które, po oskarżeniu „Po prostu” m.in. o tzw. rewizjonizm, rozwiązały tygodnik 2 października 1957 roku. (Było to nota bene bezpośrednim powodem wycofania przez Giedroycia poparcia dla Gomułki.) Opracowaną przez Jeleńskiego antologię tekstów z tygodnika, zawierającą także teksty zdjęte przez cenzurę, możemy traktować jako swoisty hołd złożony redakcji warszawskiego pisma.

Lista przekładów Jeleńskiego nie kończy się na wierszach zamieszczonych we francuskiej antologii polskiej poezji. Wespół z Pierrem Emmanuelem przełożył także - co ciekawe - wiersze Karola Wojtyły ${ }^{247}$. O pracy nad tym wydaniem pisze w przedmowie Emmanuel:

[...] niełatwa była to obiektywnie służba, gdyż nie znam polskiego języka. Miałem przed sobą surowe tłumaczenie dokonane w Polsce przez Annę Turowiczową, która zaopatrzyła je w cenny aparat krytyczny. Jestem jej wdzięczny za tę pracę, pozwoliła mi ona lepiej zrozumieć jak polski czytelnik odbiera wiersze Wojtyły, z których wiele odnosi się do historii, w której się urodził i żyje nadal. Jej uwagi, często ważkie, pomogły mi zrozumieć duchowy wymiar tej poezji. Piękny, rasowy przekład angielski poety Jerzego Pietrkiewicza, Brytyjczyka polskiego pochodzenia, był mi użyteczny, mimo że

${ }^{245}$ A. Wat, Korespondencja, cz. 2, s. 147.

${ }^{246}$ Zob.: G. Wołowiec, „Po prostu”, [hasło w:] Słownik realizmu socjalistycznego, red. Z. Łapiński, W. Tomasik, Kraków 2004, s. 200-203.

${ }^{247}$ K. Wojtyła, Poémes, Paris 1979. 
dotyczy jedynie fragmentów dzieła. Nie mógłbym jednak dokonać tej pracy, gdyby mój przyjaciel Konstanty Jeleński, którego przekłady są we Francji wysoko cenione, nie podjął się sporządzenia pierwszej wersji, dającej mi ekwiwalent rytmiczny i słuchowy, aby wiersze te mogły mi zadźwięczeć w wyobraźni. Niezbędny ten wkład sprawia, że razem podpisujemy tę wspólnie opracowaną adaptację ${ }^{248}$.

Warto także wspomnieć, że w 1984 ukazał się paryski zbiór Poémes 1934-1982 Czesława Miłosza, opracowany przez Jeleńskiego, który również podjął się tłumaczenia części opublikowanych w tomie utworów. Bez niego i jego wysiłków nie ukazałby się także francuski przekład książki Adama Michnika Kościót, lewica, dialog ${ }^{249}$.

Jeleński tłumaczył właściwie stale, wszystko co uznawał za cenne: teksty literackie (poza Gombrowiczem także wspomniane dzieła Miłosza, ale i innych poetów, nie tylko polskich $^{250}$; tekst dramatyczny — Balkon zaprzyjaźnionego z Leonor Fini Jeana Genêta

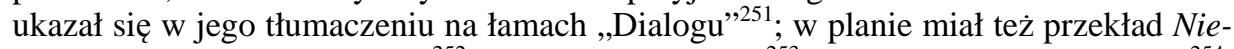
-Boskiej komedii na francuski ${ }^{252}$ ), krytycznoliterackie ${ }^{253}$, niekiedy teksty polityczne ${ }^{254}$, wspomnieniowe ${ }^{255}$, warte uwagi przedmowy do zagranicznych wydań polskich ksią-

${ }^{248}$ P. Emmanuel, Wiersze Karola Wojtyły po francusku, tłum. K. A. Jeleński, Kultura 1980 nr 3(390), s. 120-121. nimskiej.

${ }^{249}$ L'Église et la gauche. La dialogue polonais (Paris 1979) w tłumaczeniu Agnieszki Sło-

250 Jeleński tłumaczył niekiedy pojedyncze wiersze, które w jakiś sposób go urzekły. Jednym z takich utworów był wiersz Gilberta Lely La parole et le froid, na który natrafił w antologii francuskiej poezji Jean-Francois Revela. Odczytany na nowo, przywiódł skojarzenie z późną twórczością Miłosza i nieodpartą chęć przetłumaczenia; zob.: G. Lely, Stowo i chtód, Zeszyty Literackie 1985 nr 10, s. 10-11; zob. także: CO, s. 395-396. Wiersz ten, zaczynający się od słów „Człowiek dosięgający wieku, w którym niedługo odejdzie od siebie, /Uchwyci każdą okazję bycia sam na sam ze sobą", Jeleński przełożył dwa lata przed śmiercią. Poza klimatem akcentującym schyłek życia, nieubłagane odejście, jest w nim też coś charakterystycznego z samego Jeleńskiego: nieokreślona samotność i nieskrywany indywidualizm. W „Zeszytach Literackich” ukazał się m.in. także jego przekład wiersza Oskara Miłosza - Zmarli sa wszyscy pijani (1986 nr 15 , s. 85-86; $1995 \mathrm{nr} 1-50$ /dodatek specjalny/, s. 29-30) oraz tytułowy wiersz z tomu Alibi Elsy Morante (1989 nr 25, s. 29-33, także CO 429-433). W twórczości Morante Jeleński odnajdywał interesujący go splot rzeczywistości z osobistą mitologią, ich stałą konfrontację, nie tłumioną, naturalną, niemal ,przymusową”. Był to dla niego typ twórczości bardzo pociągający, zajmujący, jak zauważał, we współczesnej literaturze miejsce samotne.

${ }^{251}$ J. Genêt, Balkon, Dialog 1957 nr 10, s. 25-66.

${ }^{252}$ W 1976 pisał do Miłosza z Paryża: ,,pod wpływem tego co piszesz o Krasińskim w History of Polish Literature odczytałem Nie-Boska i mam wielką ochotę przetłumaczyć ją na francuski. Myślę, że można by to z powodzeniem tu wystawić w teatrze (wydanie miałbym zapewnione). To rzeczywiście fascynująca rzecz — a miejscami bardzo naprawdę piękna! [...] Otóż nękają mnie w Nie-Boskiej te nieszczęsne Przechrzty — które «niby splotami niezmiernej gadziny oplotły świat czcicielów Krzyża» etc. Wiesz jak nieznośny jest dla mnie ten polski antysemityzm, znów to rzucić tym okropnym Francuzom «na pastwę» - trochę mi wstydno"; K. A. Jeleński, Z listów do Czestawa Miłosza, (1995), s. 78.

${ }^{253}$ Zob. np.: M. Sperber, „La prise du pouvoir”, tłum. K. A. Jeleński, Kultura $1954 \mathrm{nr}$ 3(77), s. 129-134.

${ }^{254}$ Zob. np.: Z. Brzeziński, Przyszłość Jałty, tłum. K. A. Jeleński, Kultura 1985 nr 1-2(448449), s. 119-142; F. Fejtö, Od prowokacji do rewolucji, Kultura 1956 nr 12(110), s. 13-18; F. Fejtö, Przyczyny rewolucji węgierskiej, Kultura 1957 nr 5(115), s. 165-181.

${ }^{255}$ Zob. np.: Generał [Ch.] de Gaulle, Mémoires de guerre (Fragmenty), tłum. K. A. Jeleński, Kultura 1954 nr 12(86), s. 26-36; J. Gorkin, Przyczynek do biografii Rokossowskiego, tłum. 
żek ${ }^{256}$, efektowne aforyzmy Lichtenberga etc. Z tego wszystkiego największą przyjemność sprawiało mu chyba tłumaczenie poezji:

Od dawna jestem przekonany, że jedyną doskonałą lekturą wiersza jest przetłumaczenie go na obcy język. Lubię tłumaczyć poezję, każdy nowy zachwyt nad polskim wierszem wiąże się u mnie z pokusą przełożenia go na francuski, mam zawsze coś ,na warsztacie”. Jest to przyjemność całkiem odmienna od tłumaczenia prozy, związanego z terminami, stołem, słownikami, jednym słowem z pracą. Tłumaczyć wiersz to czysta rozrywka, ma coś z krzyżówki i pozwala wypełnić chwile nudy i zmęczenia; kilka linijek ma się w głowie, można nimi igrać w metrze, w poczekalni u dentysty, w kolejce do ki$\mathrm{na}^{257}$.

Pisze też o dodatkowej przyjemności, jaką była dla niego konfrontacja efektów swojej pracy z przekładami w innych językach. Takiego porównania dokonał Jeleński m.in. z wykorzystaniem wiersza Dziecię Europy Czesława Miłosza. Kompilując niemieckie tłumaczenie Karla Dedeciusa, angielskie Jana Darowskiego, włoskie Pietro Marchesaniego, ze swoim francuskim i polskim oryginałem, przeprowadził swoisty eksperyment:

Moje doświadczenie jest niewątpliwie ciekawostką, gdyż nikt chyba nigdy nie wpadł na ten absurdalny pomysł sklecenia składniowo i gramatycznie poprawnego wiersza z oryginału i czterech tłumaczen ${ }^{258}$.

Każdy z pięciu kolejnych wersów utworu Jeleński układał w innym języku:

Postanowiłem oczywiście zacząć przekładaniec od polskiego (P), który wraca co piątą linię. Ze względów słuchowo-estetycznych zdecydowałem oddzielić języki łacińskie francuski (F) i włoski (W) - niemieckim (N) lub angielskim (A). Pozwalało mi to zatem na serie PFNWA, PWAFN, PNWAF, PAFNW (itd.) ${ }^{259}$.

Pomysł rzeczywiście niecodzienny, zważywszy na gramatyczną poprawność, którą udało się Jeleńskiemu zachować. Istotny jest także konkretny wybór przesiąkniętego ironią utworu, który Miłosz napisał w roku 1946, jako pracownik konsulatu PRL w Nowym Jorku. Jeleński uznał go za ważny, wręcz „przełomowy”, oczywiście odpowiadał mu także pod względem konstrukcyjnym.

Na zorganizowanym przez Centre d'action poétique i Francuski PEN-Club w 1985 roku spotkaniu w krypcie kościoła św. Magdaleny w Paryżu, poświęconym poezji prześladowanych i wygnańców, Jeleński czytał własne przekłady wierszy Miłosza, Herberta i Zagajewskiego. Ten rodzaj „,ciekawszej i pożyteczniejszej krzyżówki”, jak nazywał pracę nad przekładem, dawał mu satysfakcję nieprzerwanie przez wiele lat.

Za swoje wysiłki translatorskie był wielokrotnie wyróżniany. W 1966 przyznano mu za nie nagrodę Fundacji im. A. Jurzykowskiego w Nowym Jorku. „Za owocną pracę dla krzewienia znajomości literatury polskiej za granicą” otrzymał w roku 1968 nagrodę literacką Fundacji im. Kościelskich w Genewie ${ }^{260}$. Za przekłady poezji na

K. A. Jeleński, Kultura 1954 nr 3(77), s. 115-118; A. Russovich, Moja przyjaźń z Witoldem, tłum. K. A. Jeleński, Kultura 1984 nr 3(438), s. 145-151.

${ }^{256}$ Zob. np.: M. Nadeau, $O$ „,testamencie” Gombrowicza, tłum. K. A. Jeleński, Kultura 1976 nr 3(342), s. 137-140; zob. także: CO, s. 440-444.

${ }^{257}$ K. A. Jeleński, Makaroniczny eksperyment, [w:] CO, s. 445.

${ }^{258}$ Tamże, 447-448.

${ }^{259}$ Tamże, s. 448.

${ }^{260}$ Zob.: Komunikat Fundacji im. Kościelskich, Kultura 1969 nr 1-2(256-257), s. 185. Wysokość nagrody Jeleński przeznaczył na Fundusz pomocy uchodźcom Międzynarodowego Stowarzyszenia Wolności Kultury w Paryżu. 
francuski, wraz z Pierrem Emmanuelem, został także nagrodzony przez Polski PEN Club w roku 1981. Dorobek pisarski, edytorski ale także właśnie translatorski był doceniony również przez samą „Kulturę”, która przyznała Jeleńskiemu w roku 1982 Nagrodę Literacką im. Zygmunta Hertza ${ }^{261}$.

Rola Jeleńskiego jako tłumacza oznaczała chyba coś więcej. Zofia Romanowiczowa wspomina go, jako tłumacza w dosłownym i przenośnym znaczeniu tego słowa: „Tłumaczyć, to jest otwierać drzwi. Między językami, między ludźmi. Kot był zawsze gotów otwierać drzwi, wprowadzać, pomagać” ${ }^{262}$. Zdaje się to być bardzo celną pointą tej części jego twórczości.

\section{Nieuchwytny}

W roku 1973 Jeleński zostaje dyrektorem administracyjnym Centre Royaumont pour une Science de l'Homme, założonym i kierowanym przez swojego przyjaciela Jacques'a Monoda — francuskiego biochemika, laureata Nagrody Nobla. Jak pisze Wojciech Karpiński:

Kot tam także zajmował się pośrednictwem: tłumaczył programy badawcze, formułowane przez naukowców, na język zrozumiały — i interesujący — dla fundacji mających finansować te prace nad budową mostów między kulturą i naturą, biologią, genetyką, socjologią, filozofią. Odczytywanie, łamanie, budowanie kodów to przecież była istota jego talentów: w pracy i w życiu ${ }^{263}$.

Jeleński pracował tam do 1976, do śmierci Monoda. W tym samym roku Pierre Emmanuel zatrudnił go jako doradcę w Institut National de l'Audiovisuel — instytucji badawczo-doświadczalnej francuskiego radia i telewizji, w której zajmował się publikacjami Instytutu, sporządzał raporty z lektur branżowej prasy. Brał także udział w pro-

${ }^{261}$ Zob.: Nagrody Literackie im. Zygmunta Hertza: K. A. Jeleński, Kultura 1982 nr 12(412-413), s. 144-146.

${ }^{262}$ Z. Romanowiczowa, Chwile oderwane, Zeszyty Literackie $1988 \mathrm{nr}$ 21, s. 182.

${ }^{263}$ W. Karpiński, Uśmiech Kota, s. 68. W liście do Czapskiego datowanym na rok 1971 Jeleński pisze: „Nie wiem, czy Ci mówiłem, że Fundacja Royaumont zmieniła zupełnie program. Centralnym punktem tego nowego programu jest Institut Royaumont de bio-anthropologie z Jacques Monod, Salvatorem Lurią, Edgarem Morinem itd. Celem jest opracowanie czegoś w rodzaju nowej wizji człowieka i społeczeństwa w oparciu o nowe odkrycia biologiczne. Otóż zamówili u mnie projekt programu kulturalno-artystycznego, który byłby z tym punktem centralnym powiązany. Praca jest interesująca, bardzo nawet interesująca, bo staram się wytłumaczyć tym wielkim uczonym, że sprawa des valeurs dépassées et de la nouvelle éthique scientifique nie jest tak prosta, jak im się wydaje. Jeśli chodzi o świat «fizyczny», to być może, że wszystkie o nim pojęcia «pré-scientifiques» są przestarzałe, nieważne. Ale jeśli chodzi o człowieka, nigdy nie uwierzę, że intuicje poetów, artystów, mistyków, filozofów są równie «nieważne», równie «przestarzałe». Wbrew temu, co myśli Jacques Monod - Dostojewski wie więcej o człowieku od niego. Pamiętasz — chyba z Zapisków z podziemia (?) - to zdanie Dostojewskiego, że człowieka nie można uszczęśliwić; że nawet jak mu najrozsądniej i najpraktyczniej przedstawisz możliwą do urzeczywistnienia wizję utopii, on ją jeszcze zniweczy. Monod (w ogóle współczesna nauka) żyją właściwie w przekonaniu, że odkrycie DNA — odkrycie, na jakim programie opiera się ludzki «komputer», załatwia właściwie całą sprawę. Tymczasem jedyną ciekawą sprawą byłoby odkrycie, czy i jak ta sprawa poruszona przez Dostojewskiego figuruje w bio-dziedzicznym programie. Co jest «wrodzone», a co nabyte? To jest moja myśl centralna raczej tło niż materiał programu, w którym staram się naszkicować szereg możliwych dialogów między «uczonym» $\mathrm{i}$ «artystą» (choćby zresztą tak centralna i we współczesnej nauce, i współczesnej sztuce kwestia du hasard)"; K. A. Jeleński, Listy z Korsyki..., s. 43. 
dukcji serii programów dla francuskiej telewizji z cyklu „Regards Entendus”, w których konfrontowano dzieła sztuki z klasycznymi tekstami na ich temat ${ }^{264}$. W 1987 przeszedł na emeryturę, którą cieszył się dwa miesiące. Zmarł w szpitalu amerykańskim w Neuilly 4 maja tegoż roku. Pochowany został w Saint-Dye nad Loarą, niedaleko zamku Chambord. W tym samym grobie spoczywają także zmarły w 1980 Stanislao Lepri i Loenor Fini, zmarła w 1996. Przed śmiercią zniszczył sporą część swoich dokumentów. Zostały słowa opublikowane, które dają wskazówki, pomagają rekonstruować myśl i skryte oblicze.

W sierpniu roku 1952, z rzymskiej agendy FAO Jeleński pisał do Czapskiego:

Piszesz: ,ja chcę, żebyś nie był tylko kunsztowną maszyną akustyczną". Ale przecież to, czym się jest, rozgrywa się tak głęboko, że żadne rady ani nawet decyzje własne tu nie pomogą. Ty istniejesz jako chrześcijanin, katolik, i wszystko to, co robisz wtedy ma drugorzędne znaczenie, bo wychodzi gdzieś głęboko z Ciebie samego i musi mieć jakiś związek. To, co robiłem i myślałem, nie miało właściwie nigdy głębokiego realnego związku. Byłem może (w przypadkowym porządku): liberałem, synem, humanistą, czytelnikiem, sumiennym urzędnikiem, Polakiem, przyjacielem, kochankiem, pederastą itd. „Kot Jeleński” — postać nieco proteuszowska, zależnie od tego, przez kogo odzwierciedlana. Oczywiście, jest szereg przyrządów, które pomagają do fikcyjnej integracji: własny wygląd fizyczny, kolejność wypadków życia, przyjaźnie utrzymywane, aby upewnić się, że się istnieje, twierdzenia intelektualne, filozofia dobrana do pewnego eklektyzmu i do „historycznego” podejścia do świata i życia (Croce się do tego dobrze nadaje ze swoim rozbiciem ,jedności ducha" na odmienne, a jednak zespolone dziedziny) ${ }^{265}$.

Samoświadomość Jeleńskiego była wyjątkowa. Zdawał sobie doskonale sprawę, już jako młody człowiek, że dla niego, jako ateisty, unikającego w dodatku ideologicznych deklaracji, określenie przyporządkowujące do konkretnej misji jest sprawą trudną. Więcej nawet: jak wskazywałyby cytowane powyżej słowa, wiedział, że tego typu integracja, wydobycie całości z własnego ja, jest w jego przypadku właściwie niemożliwa $\mathrm{i}$ — co też istotne — zdawał się nad tym nie ubolewać.

Jeleński wie, że brak mu osi, wokół której jego tożsamość mogłaby się skrystalizować, jedne role recytuje $\mathrm{z}$ pamięci, inne $\mathrm{z}$ pasją improwizuje, ale żadna $\mathrm{z}$ nich nie jest główna i najważniejsza, żadna nie daje mu poczucia siły i zdecydowania, zresztą, ani za jednym, ani za drugim nie tęskni. Ceni sobie wielość ról, wewnętrzną lekkość i swobodę, rozluźnienie ${ }^{266}$

— pisze o Jeleńskim Andrzej Stanisław Kowalczyk. Jan Zieliński, efektownie trawestując tytuł tomu Jeleńskiego, nazywa go ,zbiegiem z okoliczności”267, prawdą jest bowiem, że zgrabnie on im umyka. Czując się w wielu miejscach jak u siebie, nie chce zaznać poczucia spełnienia w swoim życiu ,zewnętrznym”, stale poszukuje. O swoich najgłębszych, wewnętrznych poszukiwaniach, mówił niewielu. Uciekał przed przypisywaniem sobie roli, przed etykietkami, unikał deklaracji. Wierzył, że nie świadczy to o istocie. W dalszej części cytowanego listu dodaje:

Czasem jednak wydaje się — nie ,wydaje się" — naprawdę: czasem jednak coś takiego się dzieje, co daje poczucie ,istnienia” — jakieś jądro formuje się bardzo głęboko i nie-

\footnotetext{
${ }^{264}$ Por.: K. A. Jeleński, Zarys życiorysu, [w:] J. Giedroyc, K. A. Jeleński, Listy..., s. 470.

${ }^{265}$ K. A. Jeleński, Listy z Korsyki..., s. 10-11.

266 A. St. Kowalczyk, Od Bukaresztu do Laffitów..., s. 223.

267 J. Zieliński, Zbieg w krainę okoliczności, Twórczość 1984 nr 6, s. 90-96.
} 
wyraźnie. Nie można do tego dojść celowo - to wszystko jest właściwie kwestią „otwarcia” jakichś zatkanych kanałów, które są wtedy przepłukane i oczyszczone. [...] chciałbym Ci powiedzieć, że to, „,co będę robił” albo „czemu się poświęcę”, jest dla mnie poniekąd w tej chwili mniej ważne, niż to po prostu czym jestem ${ }^{268}$.

Czapski dążył do integracji tego, czym się jest i tego, co się robi. Jeleński prawdopodobnie wiedział, że takie scalenie byłoby sui generis ulgą, otworzyłoby drogę, która systematycznie przynosi konsekwentne i klarowne odpowiedzi. To nie było mu jednak pisane. Kapitalnym wsparciem okazała się Leonor Fini. To dzięki niej mógł w tym samym liście dodać: „Teraz czuję, jakby odpadły ze mnie jakieś łuski. Życie jest trudniejsze, ale ma więcej sensu"269. Spotkanie i życie z Leonor, według słów Jeleńskiego, było dla niego rodzajem ocalenia:

[...] jedynym ratunkiem dla ludzi o [...] moim charakterze (bo pod moją „łatwością” i zdolnością adaptacji leży abulia i abnegacja, i głębsze życie samotne moje prowadziłoby zapewne do kloszarda) jest spotkanie kogoś takiego jak Leonor. Wierz mi, Józiu, że znalazłem istotę niezwykłą, która mi daje spokój i która pomaga mi usunąć pustkę z życia nie przez metody ,zewnętrzne”, ale przez łowienie w mojej głębokiej osobowości tego, co nie jest zatrute ${ }^{270}$.

Poszukiwanie jądra osobowości, centralnego ośrodka swojego jestestwa, było dla Jeleńskiego dużo ważniejsze niż wszelkie akcje ,zewnętrzne”, które zawsze miały dla niego charakter powierzchowny. Dla niektórych mogłoby to w jakieś mierze kłócić się z jego wymaganiami wobec artystów i ich sztuki. Najbardziej wartościowa, bo najprawdziwsza, okazywała się dla niego sztuka, która odpowiadała życiu. Ta zgodność miała dla niego wymiar egzystencjalny. Obecność artysty musiała być w dziele uchwytna, liczyło się przecież to, co indywidualne, dystynktywne. Jednak wagę swoich zdolności, talentów i umiejętności lekceważył, mając świadomość, że często - nie tylko w jego przypadku — kryją one samotność i niepewność. W tym poszukiwaniu ukrytej, wewnętrznej prawdy o sobie, Leonor okazywała się niezastąpiona. W liście $\mathrm{z}$ roku 1953 pisał do Czapskiego:

Być może, że moje życie z L. jest dla mnie często smutniejsze niż byłoby moje życie samemu. Sam mam łatwość adaptacji, pociechę łatwych sukcesów, „lekkość” kogoś nie związanego, półsen gęstego erotyzmu. Ale często nie mam poczucia istnienia. To poczucie daje mi Leonor, a może właśnie moja czuła, gorąca, a jednak gorzka i smutna miłość do niej. Wiem, że zawsze — przy każdym wyborze — ,wybiorę” L. A gdybym kiedyś tego wyboru nie zrobił, to wyłącznie przez najniższe pobudki: może dążność do silniejszej (ale jakże powierzchownej) afirmacji mojego ,,ja”; może przez lenistwo (acedia), które jest moją główną wadą (wiesz, o jakim lenistwie mówię), może przez jakąś tęsknotę do erotycznego kalejdoskopu, do częstych, brutalnych pobudek zmysłowych $^{271}$.

Estetyczna wrażliwość Jeleńskiego była bardzo rozwinięta. I choć dużo pisał, próbował swych sił w malarstwie ${ }^{272}$, wyraźnie bronił się przed mianem pisarza, artysty.

${ }^{268}$ K. A. Jeleński, Listy z Korsyki..., s. 11.

${ }^{269}$ Tamże.

${ }^{270}$ Tamże, s. 18

271 Tamże, s. 16.

${ }^{272}$ Tamże, s. 14. Porównaj także: J. Giedroyc, K. A. Jeleński, Listy..., s. 146 (list do Jerzego Giedroycia z 11 sierpnia 1953). 
Pewnym wyjaśnieniem byłby tu kolejny ustęp z korespondencji, w którym Jeleński wyraża przyczynę swej fascynacji Leonor:

Jej jasność i przejrzystość, jej wspaniała konsystencja i wolność — jakby była wykuta z kryształu w blok, który lata i pływa - jest dokonana kosztem ,dépouillement” do elementów czysto pierwotnych — jej całkowitą odmową (refus) historii. Une créature bestiale et poétique — poetyczna w sensie unique — oto czym jest dla mnie Leonor. Ja oczywiście muszę znaleźć inne rozwiązanie, nie mogę, nie stać mnie niestety na tę samą wolność. Szereg fenomenów historycznych (jak wolność abstrakcyjna, nie tylko w moim konkretnym przypadku) zespoliło się zbyt istotnie i głęboko z tym, czym jestem, abym mógł je odrzucić 273 .

Być może właśnie z powodu niemożliwości osiągnięcia tego typu wolności, tak skwapliwie poszukiwał przebłysków owego uwolnienia w sztuce innych.

Jeleński bronił się, kiedy nazywano go pisarzem. „Robił wszystko, żeby uciec od obowiązku zostawienia po sobie dzieła. Jakże go irytowało, kiedy mówiłem, że go uważam za jednego z kilku najwybitniejszych pisarzy XX wieku!"274 — wspomina Wojciech Karpiński. Gustaw Herling-Grudziński notuje zaś w Dzienniku pisanym nocą:

Był wybitnym eseistą, jednym z najwybitniejszych we współczesnej literaturze polskiej, wolał jednak konwersacje od pisania [...] Nie tak dawno byłem świadkiem, jak znany wydawca francuski zaproponował mu przygotowanie tomu esejów. Wzruszył ramionami i propozycję pokwitował zdawkową formułką grzecznościową, bez krzty bodaj zainteresowania. Kiedy poszliśmy potem we dwójkę na kawę, usiłowałem go nakłonić do cofnięcia odmowy. Zaśmiał się: „Za dużo się teraz pisze i wydaje, grozi nam utonięcie w morzu zadrukowanego papieru, 275 .

W rozmowie z Piotrem Wierzbickim, na pytanie dotyczące ewentualnego wydania własnej książki, miał powiedzieć: „Nie mam takich ambicji, czuję się nie «pisarzem książki», ale «pisarzem artykułu»" ${ }^{7} 6$. W słowie wstępnym do pierwszego książkowego wydania swoich esejów, podkreślał, że nigdy nie myślał o tym, aby zebrać w tomie własne ,,artykuły napisane zawsze na skutek takiej czy innej zewnętrznej podniety”, dodając, że sam zalicza się do „wielkiego zespołu piszących, a nie do garstki pisarzy" ${ }^{277}$. Nie ukrywał okazjonalnego charakteru swojego pisarstwa. W recenzji drugiego krajowego wydania tekstów Jeleńskiego Jerzy Jarzębski pisał:

Przyszłym pokoleniom trudniej będzie zrozumieć, na czym polegała wielkość Konstantego Jeleńskiego. Nie pozostawił po sobie masywnych tomów dzieł — tylko niewielkie studia, eseje, felietony, prace przekładowe i redaktorskie. Budzą dziś podziw dla klasy intelektu i szerokości horyzontów autora, ale skłonniśmy je traktować jedynie jako zapowiedź, fragment, migawkowy wgląd w jakąś potężniejszą syntezę, która nie powstała. A raczej: powstała w innej materii ${ }^{278}$.

Jeleński, podobnie jak Jerzy Stempowski, miał wyraźne opory przed czynnością „,czernienia papieru". Najbardziej zdawała się odpowiadać mu forma możliwie najkrótsza: zwięzła, celna i pełna treściowo. Musiało wiązać się to z jego (podobnie jak u Gombrowicza) wstrętem do konstrukcji retorycznych, w których forma wynoszona jest

\footnotetext{
${ }^{273}$ K. A. Jeleński, Listy z Korsyki..., s. 11-12.

${ }^{274}$ R. Gorczyńska, Portrety paryskie, s. 288.

${ }^{275}$ G. Herling-Grudziński, Dziennik pisany noca, cz. 2, s. 106.

${ }^{276}$ P. Wierzbicki, Odkrywca odkryć, Tygodnik Powszechny $1980 \mathrm{nr}$ 51-52, s. 12.

${ }^{277}$ Oba cyt. za: K. A. Jeleński, Od Autora, [w:] ZO I, s. 5.

278 J. Jarzębski, Urok Jeleńskiego, Tygodnik Powszechny 1991 nr 12, s. 7.
} 
ponad treść. W tym wyborze, w przeciwieństwie do szeregu innych preferencji, był bardzo wyraźny.

Był jednak okres, w którym Jeleński myślał o napisaniu książki — jej tytuł roboczy brzmiał Une idée baroque ${ }^{279}$. W liście do Jerzego Giedroycia z roku 1953 pisał:

Przejeżdżając przez Neapol (byłem tylko dzień) po dwuletniej nieobecności, byłem tak uderzony siłą tego miasta, że mam wielką ochotę napisać książkę — rodzaj powieści. Byłby to spacer po „Spaccanapoli” — tej ulicy, która na pół przecina stary Neapol, ale bez żadnych celów „,erudycyjnych”, ,historycznych”, czy „kulturalnych”. Byłby to mój własny, przetworzony Neapol - z nazwami przekręconymi tak, jak ja je pamiętam, $\mathrm{z}$ wizją wspomnienia wewnętrznego, mało albo wcale nie związanego $\mathrm{z}$ rzeczywistością. Wszystko to połączone poprzez wspomnienia z realiami życia „opowiadającego”, z emigracją, polskimi wspomnieniami, z udziałem osób prawdziwych, konkretnych i fikcyjnych. Styl byłby jednak swobodnego monologu wewnętrznego, ale bez neologizmów. Oczywiście forma ta jest stara i znana [...]. Ale pociąga mnie tu nie eksperyment formalny - ale treść tego, co chciałbym powiedzieć i co mógłbym może powiedzieć tylko w tej formie (właściwie chodziłoby mnie o dwie fikcje - życia i miasta sprzeczne ze sobą — i jak je powoli wprowadzić do realnej zawartości). [...] Najgorsze, że teraz nie mogę zabrać się do pisania tego — właśnie kiedy mam czas. Jest tak, jakbym chodził ,dookoła” czegoś, co mnie pasjonuje, ale kiedy staram się skonkretyzować — wszystko znika. Oczywiście najgorszą przeszkodą jest tu moja magnetyczna dążność do banału (i często głupstwa), z chwilą gdy uwaga przestaje być wytężona. No i wielka trudność problemu „,szczerości” — jej przetworzenia — bez stawania się niewolnikiem takiej czy innej „kokieterii” — bez podlegania własnemu — oczywiście i w każdym wypadku fikcyjnemu - personnage ${ }^{280}$.

Trudno powiedzieć czy jego poświęcenie dla dzieła innych, praca biurowa - którą, pamiętajmy, musiał (chciał) przez wiele lat godzić z pisaniem ${ }^{281}-$ i niemal lekceważące podejście do własnej twórczości ${ }^{282}$, czy raczej uczucie niemożliwości satysfakcjonującego przekazania swoich wrażeń sprawiły, że książka nie została ukończona. Przyczyną mógł być po prostu fakt, że — jak miał powiedzieć Wojciechowi Karpińskiemu — jego ambicją nie było dzieło, lecz życie ${ }^{283}$. Szczęśliwie, w hojnych komentarzach do twórczości bliskich mu artystów pozostawił znaczącą cząstkę siebie.

${ }^{279}$ Faksymile strony z notatek do tego projektu Jeleńskiego odnajdujemy w Chwilach oderwanych na stronie 387. Por. także notę edytora do tej ilustracji (s. 563).

${ }^{280}$ J. Giedroyc, K. A. Jeleński, Listy..., s. 145-146. Zamiary Jeleńskiego potwierdza także Gustaw Herling-Grudziński w rozmowie z Elżbietą Sawicką: „Konstanty Jeleński, który znał dosyć dobrze Neapol, bo mieszkał tu po wojnie trzy lata z rodzicami, planował napisanie książki o Neapolu [...]. Powtarzał zresztą z uporem maniaka, że ulica via Tribunali na starym mieście, równoległa do Spaccanapoli, jest najpiękniejszą ulicą na świecie”; zob.: E. Sawicka, Przystanek Europa, Warszawa 1996, s. 184. Sam Jeleński pisał zaś do Czapskiego w liście z 1959: „Wyobraź sobie, że od kilku dni «pracuję» nad projektem książki (po raz pierwszy w życiu). Miałem takie nagłe «olśnienie» - ale nie wiem, do jakiego stopnia te rzeczy są mylne. Nie sam fakt olśnienia, ten jest doświadczeniem — ale często iluzją jest, że to można wypowiedzieć. Najczęściej są to miraże, które na papierze nikną, jak bańka mydlana schwytana w dłoń”; cyt. za: CO, s. 564.

${ }^{281}$ Wojciech Karpiński wspomina: „najinteligentniejszy człowiek, jakiego dane mi było poznać, chodzi codziennie do biura, nie zawsze na osiem godzin, ale codziennie. Był to chyba świadomy wybór"; W. Karpiński, Uśmiech Kota, s. 67.

${ }^{282} \mathrm{O}$ swoich artykułach na przykład potrafił powiedzieć: „,sporo napisałem różnych śmieci dla «Kultury»"; K. A. Jeleński, Listy z Korsyki..., s. 19.

${ }^{283}$ Zob.: W. Karpiński, Uśmiech Kota, s. 70. 
W cytowanym już artykule Jerzy Jarzębski podsumowuje:

Jeleński stworzył pewien styl oparty na wewnętrznych sprzecznościach [...]. Polegał on na połączeniu konserwatywnej spuścizny z lewicowością, dandyzmu z imperatywem społecznej służby, zaangażowania $\mathrm{w}$ walce o wolność kultury $\mathrm{z}$ tolerancją wobec ideowych przeciwników, namiętnego chłonięcia wszystkich przejawów życia z elitaryzmem i kultem Największych ${ }^{284}$.

Ten opis niebanalnej formuły Jeleńskiego wydaje mi się bardzo trafny. To bowiem, co chciałbym zaakcentować, to fakt, iż Jeleński, łącząc w ramach swego światopoglądu elementy rzeczywiście sprzeczne, sam sprzecznym nie był. Posiadał bowiem nadzwyczajną zdolność łączenia przeciwieństw w ten sposób, aby każde z nich zachowywało swą odrębność, tworząc jednocześnie z drugim (i trzecim i czwartym...) zgrabną całość. Renata Gorczyńska przyznaje, że

by opisać Kota, trzeba by odwołać się do oksymoronów. Bo był on uważny i roztrzepany, troskliwy i arogancki, bezbożny i nabożny. Był liberałem i reakcjonistą, kombatantem i pacyfistą, szydercą i kolanopokłonnym. I to nie raz jednym, a raz drugim, lecz tym wszystkim jednocześnie. Można było odnieść wrażenie, że Kotów było wielu. Moim zdaniem Kot był na koniec jeden ${ }^{285}$.

Barbara Toruńczyk wspomina Jeleńskiego jako nieuchwytnego, także dla samego siebie $^{286}$. Czytając chociażby o jego kontakcie z dziełem Miłosza, trudno oprzeć się takiemu odczuciu:

Następuje zgoda niedopowiedziana (bo ją teraz dopiero wnioskuję z doświadczenia, które trudno przekazać) nie tylko na moją śmierć, ale i na to, że nie będzie kiedyś ani wierszy Miłosza, ani ludzi, którzy by je mogli czytać: wystarcza, że jest teraz coś, o czym te wiersze świadczą. Pisząc o Ziemi Ulro, byłbym zatem tej ziemi zrezygnowanym obywatelem, nieświadomym własnego okaleczenia, paradoksalnie znajdującym ukojenie w wierszach Miłosza, który ją ma za ohydną niewolę? ${ }^{287}$

Jakże znaczący okazuje się, kończący cytat, znak zapytania. Jeleński igra nie tylko z czytelnikiem i nie tylko z Miłoszem: zdaje się mówić: „,chyba taki właśnie jestem, ale czy na pewno?".

Nieuchwytność Jeleńskiego była wynikiem jego jednoczesnej przynależności do kilku światów. René Tavernier wspomina:

Konstanty, Polak i określający się tak właśnie, był również — co chciałbym podkreślić — obywatelem świata, ciekawym wszystkich kultur i różnych środków wyrazu. Europejczyk w każdym calu, związany z historią tego starego kontynentu płodnego dzięki swym podziałom, Kot był wrażliwy na to, co mogło zdawać się jego przeciwieństwem. I tu trzeba pokreślić rolę Italii: sposobu bycia, różnorodności, sprzecznej tajemnej siły geniuszu włoskiego, o której świadczyła wieloznaczność jego uśmiechu, zniewalający urok spojrzenia ${ }^{288}$.

Jego umiejętność adaptacji i zjednywania sobie ludzi bez względu na ich poglądy, przy jednoczesnym zachowaniu własnej niezależności, z charakterystycznym humorem opisywał Miłoszowi w liście Zygmunt Hertz w roku 1961:

284 Tamże.

${ }^{285}$ R. Gorczyńska, Traf. Rzecz o Kocie Jeleńskim, Puls 1993 nr 4, s. 41-42.

${ }^{286}$ Zob. wypowiedź Barbary Toruńczyk w dyskusji o Chwilach oderwanych; Gazeta Wyborcza 4-5.04.2009, s. 27.

${ }^{287}$ K. A. Jeleński, $O$ „Ziemi Ulro” po dwóch latach, s. 10.

${ }^{288}$ R. Tavernier, Konstanty Jeleński czy tajemnica przyjaźni, s. 37. 
Kot w Hiszpanii — pisze zachwycone karty — że piękny kraj i mili ludzie. Karty pisze i ja je przechowuję, bo na nim ciąży ciągle jeszcze anatema. Polacy to zgodny narodek — jak ich jest pięciu, to jest 30 kombinacji prowadzących do kłótni, z których potem wyrasta pięć grup zasadniczych — wszyscy z wszystkimi na noże — grupka dwóch przeciwko trzem czy czterech przeciwko jednemu już nie wystarcza. I oczywiście wszystko jak najgorzej! Najdziwniejsze w tej całej historii a może diabolo logiczne, że Kot nie ma całkiem ochoty na jakąkolwiek kolaborację. Daje sobie radę sam, ma masę przyjaciół, świetną sytuację „krajową”, bo i kasa czynna od 9 do 1-ej, i miły człowiek, i stosunki, z jednej strony przez Żółtowskich, Kociubińskich od podhrabków, z drugiej strony „Volksjude”. Czyli same zalety: i pod Kardynała i pod Shaffa. A do tego francuska bohema i Genet na balkonie się wietrzący i Audiberti i Piovene i Moravia. Czyli jak ulał — ma przyjemnie wypełnione życie ${ }^{289}$.

Umiejętność bezkonfliktowego łączenia przeciwieństw przychodziła Jeleńskiemu naturalnie, znamienna dla pewnego gatunku inteligencji. Dysonans antonimów sprowadzał do spójnej harmonii. Czesław Miłosz notuje w Roku myśliwego:

Kot, niby panicz z dworu, ale jaki tam polski panicz. Włoch po ojcu, wynalazca niezwykłej formuły — i pełnej polskości, i pełnego kosmopolityzmu, trzeźwo oceniający polskość, a przecież jej zawsze wierny, podwójny we wszystkim, bo i kobiety, i chłopcy, a zarazem jednolity — gdzież mu do postaci z poczciwej szlacheckiej powieści ${ }^{290}$.

Ta skomplikowana synteza Jeleńskiego, którą mimowolnie pielęgnował przez lata, okazywała się w jego ujęciu całkowicie normalną i bezpretensjonalną. Głęboko zanurzony w tradycji ziemiańskiej, którą krytykował, ale z którą jednak się utożsamiał, był przecież wielkim entuzjastą nowoczesności, cały czas trzymającym rękę na pulsie drgań współczesnych ruchów. Swój kosmopolityzm realizował bez kompleksów, łącząc go bez szkody z wielkim przywiązaniem do Polski ${ }^{291}$. Podkreślał bliską jego sercu ideę egalitaryzmu, demokratyzmu, poruszając się jednocześnie swobodnie w kręgu europejskiej elity. Bronił kultury masowej, oddając swój czas i talent przede wszystkim kulturze wysokiej. Trwając przy uznaniu moralnych wartości podstawowych był zawsze wyrozumiały dla tych, którzy wartości te gdzieś po drodze pominęli. Niektórzy przeciwstawiali estetyzm Jeleńskiego etyce Giedroycia - to porównanie zdaje się jednak krzywdzące, z wielu powodów. Pamiętać przy tym trzeba, że nadawał on sztuce wielką rolę społeczną.

Jeleński realizował się w wielu miejscach, unikając jednak całkowitego spełnienia, które oddaliłoby go od potrzeby dalszych poszukiwań. Był do tego przewrotny, nieprzewidywalny, przekorny. W liście do Miłosza pisanym z Korsyki w roku 1964 przyznawal:

Pamiętam z dziecinnych lat rycinę Grottgera, na której katorżnicy rosyjscy żrą i piją jak świnie, rżną w kości i karty, a w kącie stoi (w głębi, na prawo) chudy, smutny, wąsisty, szlachetny Polak bodaj w kontuszu (skromnym, ale schludnym) i pogardza. Już wtedy miałem nieodpartą sympatię do żywotności tych niby „ohydnych” gęb, a silną antypatię do tego szlachetnego purytanina ${ }^{292}$.

\footnotetext{
${ }^{289}$ Z. Hertz, Listy do Czestawa Mitosza..., s. 63-64.

${ }^{290}$ Cz. Miłosz, Rok myśliwego, s. 95.

291 Jeleński nota bene nigdy nie wystąpił o obywatelstwo francuskie. Używał zawsze dokumentu uchodźcy politycznego.

${ }^{292}$ K. A. Jeleński, Z listów do Czestawa Miłosza, (2001), s. 70.
} 
Do tego wszystkiego dochodziła tajemniczość Kota, wynikająca zapewne z jego wielkiej dyskrecji, wrodzonej dystynkcji, która powodowała, że nawet dla przyjaciół istniały w nim elementy zakryte ${ }^{293}$.

Światopogląd Jeleńskiego, ,jednoosobowej instytucji”, ,ambasadora polskiej kultury w Europie", który chcemy w jakiś sposób ująć w ramy, próbując przykładać go do różnych konwencji, wymyka się. Jest nieuchwytny, wieloznaczny. Ktoś powie: „sprzeczny Jeleński” — ja wierzę, że to Jeleński doskonale łączący sprzeczności. A może ostatecznie to zbędne odróżnienie, które on sam, nie zważając na formę, jedynie skwitowałby dwuznacznym uśmiechem. Dbał przecież o wartość realną, o znaczenie prawdziwe, którego jądro może być tylko jedno. Więc może i „sprzeczny Jeleński” — Herbert powiedział przecież kiedyś, że prawda jest tam, gdzie jest sprzeczność.

${ }^{293}$ François Bondy wspomina: „Wobec Kota byłem całkowicie «odsłonięty». Znał mnie lepiej niż ja jego. Śledził wszystko, co robiłem, sam mając kilka światów, do których nie miałem dostępu. [...] Do tego dochodziła jego dyskrecja. Przez trzydzieści cztery lata naszej zażyłości ani razu nie wspomniał o swojej przeszłości żołnierza drugiej wojny światowej”; F. Bondy, Kot, s. 37. 